\title{
ÁCIDO LINOLÉICO CONJUGADO: TEORES NOS ALIMENTOS E SEU USO NO AUMENTO DA PRODUÇÃO DE LEITE COM MAIOR TEOR DE PROTEÍNA E PERFIL DE ÁCIDOS GRAXOS MODIFICADO
}

\section{SERGIO RAPOSO DE MEDEIROS}

Tese apresentada à Escola Superior de Agricultura "Luiz de Queiroz", Universidade de São Paulo, para obtenção do título de Doutor em Agronomia, Área de Concentração: Ciência Animal e Pastagens.

P I R A C I C A B A Estado de São Paulo - Brasil

Fevereiro - 2002 


\section{ÁCIDO LINOLÉICO CONJUGADO: TEORES NOS ALIMENTOS E SEU USO NO AUMENTO DA PRODUÇÃO DE LEITE COM MAIOR TEOR DE PROTEÍNA E PERFIL DE ÁCIDOS GRAXOS MODIFICADO}

\section{SERGIO RAPOSO DE MEDEIROS}

Engenheiro Agrônomo

Orientador: Prof. Dr. DANTE PAZZANESE D. LANNA

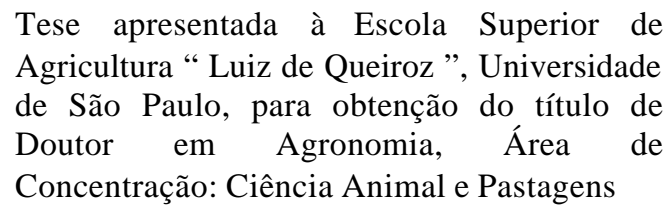

P I R A C I C A B A

Estado de São Paulo - Brasil

Fevereiro - 2002 


\section{Dados Internacionais de Catalogação na Publicação (CIP) DIVISÃO DE BIBLIOTECA E DOCUMENTAÇÃO - ESALQ/USP}

Medeiros, Sergio Raposo de

Ácido linoléico conjugado : teores nos a limentose seu uso no aumento da produção de leite, com maior teor de proteína e perfil de ácidos graxos modific ados / Sergio Raposo de Medeiros. - - Piracicaba, 2001.

$98 \mathrm{p}$.

Tese (Doutorado) - Escola Superior de Agricultura Luiz de Queiroz, 2002.

Bibliografia.

1. Ácidos graxos 2. Bovinoc ultura leiteira 3. Composição de alimentos 4. Ó leose gord ura s a nima is comestíve is 5 . Sup lemento a limenta res pa ra a nima is I. Título

CDD 636.2085

"Permitida a cópia total ou parcial deste documento, desde que citada a fonte - $\mathrm{O}$ autor" 
"Deus no dê coragem, para mudarmos o que podemos, serenidade, para aceitarmos o que não podemos, e sabedoria, para diferenciar uma das outras"

Anônimo

A Marcos, Marisa, Marta, Renato, Beatriz e André, pelo carinho que sempre demonstraram com o filho e irmão caçula e, especialmente, pelo ambiente sempre mentalmente desafiador que proporcionaram!

Aos meus sogros, Ada e Edy, pela sempre calorosa acolhida ao genro e pelo decisivo apoio que permitiu-me trocar emprego e salário por doutorado e bolsa de estudos.

Às minhas meninas queridas, Marina e Eda, que compartilharam as agruras da empreitada, a certeza que, havendo conquista, esta também a elas pertence. 


\section{Agradecimentos}

Ao Prof. Dr. Dante Pazzanese Duarte Lanna pela oportunidade, imensa satisfação de trabalharmos juntos, principalmente por sempre mostrar como o cérebro humano pode trabalhar mais rápido;

Ao Prof. Dr. Celso Boin, pelos bons exemplos e pela confiança;

Ao Prof. Dr. Mark McGuire, da Universidade de Idaho pelo envio do CLA,

À CHURC \& DWIGHT, nas pessoas do Dr. Mário e Dr. Eliot Block, pelo apoio fundamental na doação de material experimental.

Ao Dr. Luiz Aroeira e todo pessoal da EMBRAPA Gado de Leite de Juiz de Fora

A todos da Fazenda Santa Mônica, da EMBRAPA Gado de Leite, nas pessoas de Dr. Oriel Fajardo e Dr. Wilson Gomes, pela imensa ajuda e simpatia nos 6 meses da fase de suplementação.

Aos colegas do Laboratório de Nutrição e Crescimento Animal : Adriana, Alexandre, Amanda, André, Andrea, Dimas, Juliano, Liliane, Luciana, Marcelo, Marco Antônio, Max, que fizeram esse tempo tão agradável quanto possível.

À FAPESP pela concessão da bolsa de estudos e auxílios de projetos ligados à esta tese 


\section{SUMÁRIO}

\begin{tabular}{|c|c|}
\hline \multicolumn{2}{|l|}{ 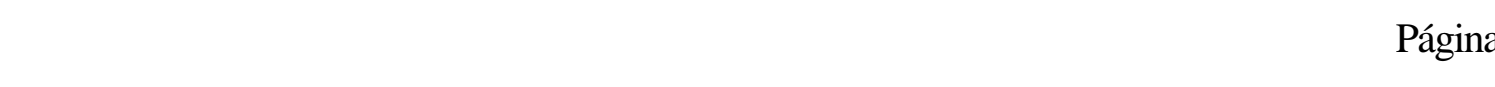 } \\
\hline LISTA DE FIGURAS . & \\
\hline LISTA DE TABELAS ............ & ix \\
\hline RESUMO & xii \\
\hline SUMMARY ...................... & xiv \\
\hline 1 INTRODUÇÃO & 1 \\
\hline 2 REVISÃO DE LITERATURA & 4 \\
\hline 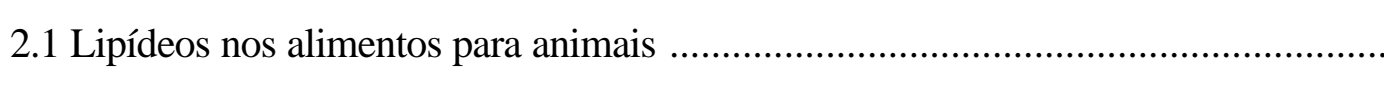 & 4 \\
\hline 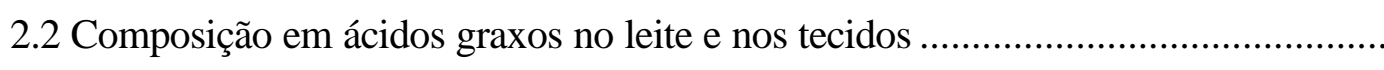 & 6 \\
\hline 2.2.1 Leite bovino & 6 \\
\hline 2.2.2 Bovinos de Corte & 11 \\
\hline 2.1.3 Suínos e Frangos . & 16 \\
\hline 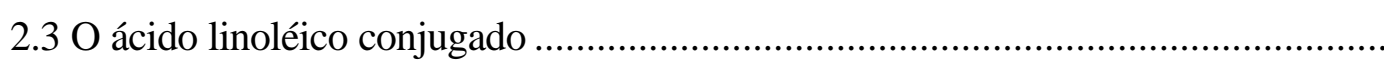 & 18 \\
\hline 2.31 Produção de CLA................... & \\
\hline
\end{tabular}

2.3.2 Variação da concentração do CLA nos diferentes no leite e tecidos..................... 22

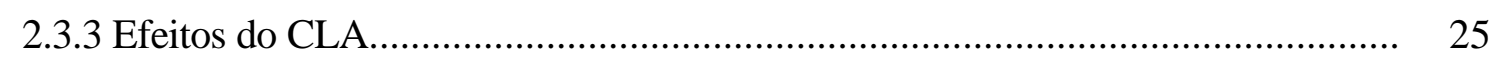

2.3.3.1 Efeitos anticarcinogênico ......................................................................... 26

2.3.3.2 Efeitos na mudança da composição do leite ..................................................... 27

2.3.4 Possíveis mecanismos de ação............................................................................ 31

3 MATERIAL E MÉTODOS .......................................................................... 34

3.1 Fase I - Determinação do teor de CLA em vários alimentos............................... 34 
3.1.1 Amostras de carne bovina ............................................................................ 34

3.1.2 Amostras de leite .................................................................................. 35

3.1.3 Amostras de suínos e aves ........................................................................ 36

3.1.4 Amostras de dieta humana completa............................................................ 36

3.1.5 Determinação dos perfis de ácidos graxos das amostras ................................... 36

3.1.6 Análise Estatística ............................................................................... 37

3.2 Fase II - Suplementação de vacas lactantes em pastejo com sais de cálcio de

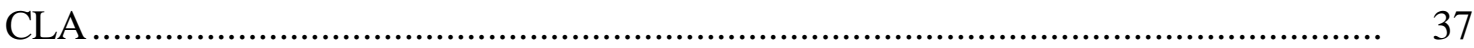

3.2.1 Animais, manejo e tratamentos .................................................................. 40

3.2.2 Avaliação da produção e composição do leite ……………………………….... 40

3.2.3 Avaliação do teor do nitrogênio uréico do leite .................................................. 41

3.2.4 Avaliação dos teores plasmáticos ..................................................................... 41

3.2.5 Análise Estatística .................................................................................... 41

4 RESULTADOS E DISCUSSÃO ………………….................................... 43

4.1 Perfis de ácidos graxos das amostras de leite coletadas em 6 fazendas com rebanhos de espécies diferentes (Bos taurus vs Bos indicus) em duas épocas do ano

4.2 Perfis de ácidos graxos das amostras de carne bovina coletadas de 3 sistemas de produção

4.3 Perfis de ácidos graxos da carne de monogástricos (Aves e Suínos).................... 53

4.4 Comparação de todos os valores de CLA total ................................................... 56

4.5 A refeição total e os valores de CLA .................................................................. 57

4.6 Efeitos da suplementação com CLA de vacas lactantes em pastejo sobre a produção, composição de leite, níveis plasmáticos, condição corporal e peso dos

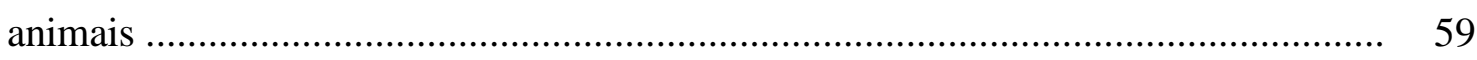

4.6.1 Produção e composição do leite …………………………………………….... 59

4.6.2 Peso e condição corporal dos animais .............................................................. 64

4.6.3 Perfil de ácidos graxos do leite ................................................................. 67

4.6.4 Valores de nitrogênio uréico do leite (MUN) ................................................. 75

4.6.5 Variáveis plasmáticas ..................................................................................... 76 
4.6.6 Contagem de Células Somáticas ........................................................................ 78

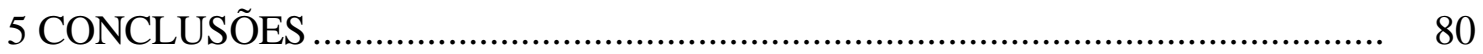

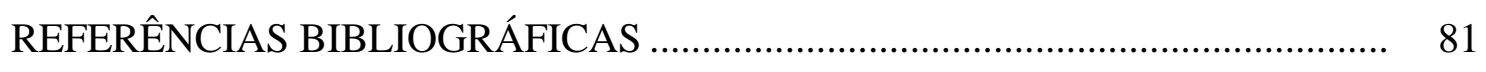

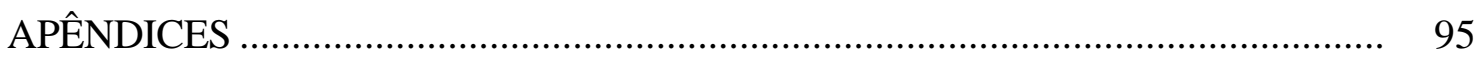




\section{LISTA DE FIGURAS}

Página

1 Esquema da produção de CLA em bovinos. Os passos do quadro a esquerda, ocorreriam no rúmen, 19

2 Efeito da infusão abomasal of CLA-60 no teor de gordura do leite.................... 30

3 Regressão entre os teores de ácido vaccênico e de ácido rumênico no leite ......... 47

4 Regressão entre os valores de ácido vaccênico e os teores de CLA total no leite. . 48

5 Concentrações de ácido linoléico conjugado (CLA) total para todas as amostras de origem animal.

6 Dispersão dos dados e regressões dos valores médios de produção de leite das vacas durante o experimento. A equação de regressão superior é dos animais que receberam CLA no período de tratamento e a outra daqueles que receberam Megalac $\AA$

6 Regressão entre os teores de gordura do leite e o isômero t10,c12 


\section{LISTA DE TABELAS}

Página

1 Composição de ácidos graxos de alguns alimentos utilizados na nutrição de

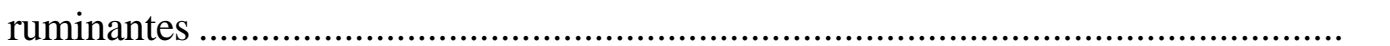

2 Perfis de ácidos graxos selecionados do leite de alguns experimentos com

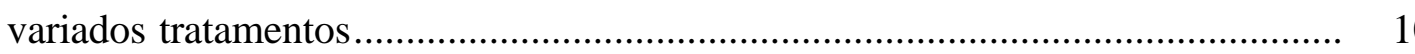

3 Comparação da composição dos principais ácidos graxos dos vários depósitos lipídicos em bovinos

4 Perfis de ácidos graxos de suínos na gordura subcutânea, de carne magra, do músculo latissimus e da gordura abdominal, da coxa e do peito de frango

5 Valores médios encontrados em alguns alimentos

6 Composição do concentrados oferecido às vacas do experimento e composição química estimada

7 Resultados das análises bromatológicas dos concentrados oferecidos às vacas do experimento e composição química estimada

8 Médias dos perfis de ácidos graxos das fazendas amostradas separadas por raça e época. $(\mathrm{g} / 100 \mathrm{~g})$

9 Teores (\% dos ácidos graxos totais) de ácidos graxos de diferentes tamanhos de cadeia e saturação e relações entre ácidos graxos de diferentes saturações do leite $(\mathrm{g} / 100 \mathrm{~g})$ 
10 Porcentagem dos ácidos graxos Vaccênico (C18:t1), Rumênico (C18:c9,t11), 18:t10,c12 e CLA total nos sistemas de produção em 2 épocas do ano3. (g/100g) ......... 46

11 Perfil de ácidos graxos na carne bovina de diferentes sistemas de produção (g/100g) ... 50

12 Teores de ácidos graxos na carne bovina das diferentes sistemas de produção.............. 51

13 Teores de ácido linoléico conjugado cis9, trans 11 na carne bovina de diferentes sistemas de produção (mg/g gordura)................................................................ 52

14 Perfis de ácidos graxos da carne de Aves e Suínos (g/100g) ..................................... 54

15 Teores de ácido linoléico conjugado (CLA) da carne de aves e da carne de suínos (mg/g gordura)

16 Descrição das dietas coletadas, tipo e peso das carnes (em matéria original) e valor de CLA total.

17 Valores de MS, teor de gordura. Descrição das dietas coletadas, peso das carnes e do acompanhamento (em matéria original) e consumo diário de CLA total.

18 Produção e composição de leite dos animais recebendo Megalac (Controle) ou CLA60 (CLA) dos 28 aos 84 dias em lactação.

19 Produção e composição de leite dos 85 aos 112 dias em lactação dos animais que receberam Megalac (Controle) ou CLA-60 (CLA) dos 28 ao 84 dias em lactação (Período Residual)

20 Peso Vivo em Jejum e Escore de Condição Corporal dos 28 aos 84 dias em lactação (Período de Tratamento) dos animais recebendo Megalac (Controle) ou CLA-60 (CLA) e dos 85 aos 112 dias em lactação (Período Residual)

21 Perfil de ácidos graxos do leite dos animais recebendo Megalac (Controle) ou CLA-60 (CLA) dos 28 aos 84 dias em lactação (Período de Tratamento) e dos 85 aos 112 dias em lactação (Período Residual)

22 Perfil de ácidos graxos C 18:1 do leite dos animais recebendo Megalac (Controle) ou CLA-60 (CLA) dos 28 aos 84 dias em lactação (PeríododeTratamento) e dos 85 aos 112 dias em lactação (Período Residual)

23 Composição dos Perfis de ácidos graxos do leite dos animais recebendo Megalac (Controle) ou CLA-60 (CLA) dos 28 aos 84 dias em lactação (Período de Tratamento) e dos 85 aos 112 dias em lactação (Período Residual) separados por tipo de ligação e tamanho da cadeia. 
24 Produção de ácidos graxos do leite dos animais recebendo Megalac (Controle) ou CLA-60 (CLA) dos 28 aos 84 dias em lactação (Período de Tratamento) e dos 85 aos 112 dias em lactação (Período Residual)

25 Produção diária de ácidos graxos do leite (grama) C18:1 t do leite de vacas animais recebendo Megalac (Controle) ou CLA-60 (CLA) do $28^{\circ}$ ao $84^{\circ}$ dias em lactação (Período de Tratamento) e do $85^{\circ}$ aos $112^{\circ}$ dias em lactação (Período Residual) ...........

26 Relação enrtre ácidos graxos saturados e insaturados de vacas recebendo Megalac (Controle) ou CLA-60 (CLA) do $28^{\circ}$ ao $84^{\circ}$ dias em lactação (Período de Tratamento) e do $85^{\circ}$ aos $112^{\circ}$ dias em lactação (Período Residual)

27 Teores de nitrogênio uréico do leite $(\mathrm{mg} / 100 \mathrm{~mL})$ de animais recebendo Megalac (Controle) ou CLA-60 (CLA) do $28^{\circ}$ ao $84^{\circ}$ dias em lactação (Período de Tratamento) e do $85^{\circ}$ aos $112^{\circ}$ dias em lactação (Período Residual) quando receberam a mesma dieta

28 Teores de variáveis plasmáticas de vacas recebendo Megalac (Controle) ou CLA-60 (CLA) do $28^{\circ}$ ao $84^{\circ}$ dias em lactação (Período de Tratamento) e do $85^{\circ}$ aos $112^{\circ}$ dias em lactação (Período Residual) quando receberam a mesma dieta

29 Logarítmo do número de células somáticas (CCS) de animais recebendo Megalac (Controle) ou CLA-60 (CLA) do $28^{\circ}$ ao $84^{\circ}$ dias em lactação (Período de Tratamento) e do $85^{\circ}$ aos $112^{\circ}$ dias em lactação em mais a suplementação de gordura (Período Residual) 


\section{ÁCIDO LINOLÉICO CONJUGADO: TEORES NOS ALIMENTOS E SEU USO NO AUMENTO DA PRODUÇÃO DE LEITE COM MAIOR TEOR DE PROTEÍNA E PERFIL DE ÁCIDOS GRAXOS MODIFICADO}

Autor: SERGIO RAPOSO DE MEDEIROS

Orientador: Prof. Dr. DANTE PAZZANESE D. LANNA

\section{RESUMO}

Os ácidos linoléicos conjugados (CLA) são potentes anticarcinogênicos em animais de laboratório e inibidores da lipogênese na glândula mamária, fígado e tecido adiposo. No primeiro experimento, foram determinados os teores de CLA de alimentos e o consumo total de CLA em dietas brasileiras. Amostras de leite foram coletadas em rebanhos Holandeses (B. taurus) e Gir (B. indicus) em dois períodos (Águas x Seca). Carne bovina foi coletada de animais terminados em: 1) Pastagem suplementada com concentrado; 2) Dietas com alto volumoso e 3) Dietas com alto concentrado. Amostras de carne suína e de frango foram adquiridas em Piracicaba-SP. Dietas humanas foram

amostradas no restaurante da ESALQ. Leite de Holandês nas Águas apresentaram as médias mais elevadas $(15,8 \pm 2,9 \mathrm{mg} / \mathrm{g}$ gordura $)$. Os teores no período da Seca foram 
significativamente mais baixos, com média de $5,1 \mathrm{mg} / \mathrm{g}$ gordura. Houve menor variação entre épocas para B. indicus, (Águas, 9,7 e Seca, 8,0 mg/g gordura). O teor de CLA na carne bovina foi afetado pelo sistema de produção com valores de 2,8 $\pm 0,5 ; 4,7 \pm 1,5$ e 9,9 $\pm 2,4 \mathrm{mg} / \mathrm{g}$ gordura, respectivamente, para os animais a pasto, com alto volumoso e alto concentrado. Carne de monogástricos apresentaram os menores valores (frango, 1,0 e suínos, 0,2 mg/g gordura). O experimento 2 estudou os efeitos da suplementação de CLA na produção e composição do leite em 30 vacas cruzadas pastejando estrela africana (Cynodon nlenfuensis var. nlenfuensis). O suplemento (4kg/dia) foi formulado para prover $115 \%$ das exigências de proteína metabolizável, sendo fornecidos 150g/cab/dia de Megalac ${ }^{\circledR}$ (Controle) ou 150g/cab/dia de sais de cálcio de CLA (CLA60, Church \& Dwight, Princeton, NJ) da $4^{\mathrm{a}}$ a $11^{\mathrm{a}}$ semana de lactação (período de tratamento). Os efeitos residuais foram avaliados entre a $12^{\mathrm{a}}$ e a $15^{\mathrm{a}}$ semana (período residual). $\mathrm{O}$ tratamento com CLA aumentou a produção de leite $(\mathrm{P}=0.056)$ e reduziu o teor de gordura de 2,86 para 2,05\% $(\mathrm{P}<0,01)$ e a produção de gordura de 437 para 349 $\mathrm{g} /$ dia $(\mathrm{P}<0,01)$. Houve aumento de $10 \%$ no teor de proteína $(2,78$ para $3,05 \% ; \mathrm{P}<0,01)$ e de $19 \%$ na produção (422 para $504 \mathrm{~g} / \mathrm{dia} ; \mathrm{P}<0.01$ ). A densidade energética do leite foi reduzida $(\mathrm{P}<0.01)$ pelo CLA, sendo que o volume de leite aumentou, consequentemente as exigências de energia líquida de lactação foram reduzidas por unidade de leite produzido. A produção do leite e o teor e produção de proteína do leite dos animais tratados mantiveram-se mais elevados no período residual. O CLA reduziu os teores de ácidos graxos (AG) de cadeia curta e a proporção de AG saturados. O tratamento com CLA aumentou o teor de CLA em 30\% ( $\mathrm{P}<0.01)$ e do isômero t10,c12, em 88\%. Os resultados do experimento. 1 demonstram que, se o CLA tem efeito protetivo contra câncer sugerido pelos estudos epidemiológicos disponíveis, o enriquecimento de CLA na dieta seria desejável. A suplementação com CLA aumentou a produção de leite, alterou sua composição, e reduziu as exigências nutricionais por unidade de leite, permitindo aumentos de volume de leite e de quantidade de proteína, particularmente em ambientes onde o aporte de energia é restrito. 


\section{CONJUGATED LINOLEIC ACID: CONTENT IN FOOD AND THE USE TO INCREASE MILK PRODUCTION, TO INCREASE MILK PROTEIN CONTENT AND TO MODIFY THE FATTY ACIDS PROFILE}

\section{SUMMARY}

Conjugated linoleic acids (CLA) are potent anticarcinogenics in animal models and inhibitors of fatty acid synthesis in mammary gland, kidney and adipose tissue. In experiment 1, CLA content of some foods and total intake in Brazilian diets were determined. Milk samples were collected from Holstein herds (B. taurus) and Gir (B. indicus) herds in two seasons (Rainy x Dry). Beef samples were collected from animals finished on: 1) Pasture plus supplement; 2) High roughage feedlot diets 3) High concentrate feedlot diets. Pork and broiler samples were purchased in Piracicaba-SP. Human diets were collected at the university restaurant (ESALQ). Holstein milk at the Rainy season presented the highest values $(15.8 \pm 2.9 \mathrm{mg} / \mathrm{g}$ fat $)$. At the dry season 
values were much lower averaging $5.1 \mathrm{mg} / \mathrm{g}$ fat. For $B$. indicus there was less variation between seasons, (Rainy, 9,7 and Dry, 8,0 mg/g fat). Beef samples CLA content were affected by the production system and values were $2.8 \pm 0.5 ; 4.7 \pm 1.5$ e $9.9 \pm 2.4 \mathrm{mg} / \mathrm{g}$ fat, respectively, for pasture animals, the high roughage and high concentrate. Monogastrics had the lowest values (broiler, 1,0 and pork, 0,2 mg/g fat). Experiment 2 studied the CLA supplementation effects on milk production and composition using 30 crossbred cows grazing stargrass (Cynodon nlenfuensis var. nlenfuensis). The supplement $(4 \mathrm{~kg} / \mathrm{dia})$ was formulated to provide $115 \%$ of the metabolizable protein requirements. The control treatment was $150 \mathrm{~g} / \mathrm{cab} / \mathrm{dia}$ de Megalac ${ }^{\circledR}$ (Control) and the treatment were 150g/cab/day CLA calcium salts (CLA-60, Church \& Dwight, Princeton, NJ) from week 4 to week 11 (treatment period). Residual effects were evaluated between week 12 and week 15 (residual period). CLA treatment increased milk production $(\mathrm{P}=0.056)$ and reduced fat content from 2.86 to $2.05 \%(\mathrm{P}<0,01)$ and fat production from 437 to $349 \mathrm{~g} /$ day $(\mathrm{P}<0,01)$. Milk protein increased by $10 \%(2 ., 78$ to $3.05 \% ; \mathrm{P}<0.01$ ) and $19 \%$ in production (422 to $504 \mathrm{~g} /$ day; $\mathrm{P}<0.01$ ). Milk energy concentration was decreased $(\mathrm{P}<0.01)$ by $\mathrm{CLA}$, while milk volume increased, consequently the net energy of lactation was reduced by kilos of milk produced. Milk production and protein production and content, for the treated cows, kept higher in the residual period. CLA reduced short chain fatty acids (FA) and the proportion of saturated FA. CLA treatment increased CLA content by $30 \%(\mathrm{P}<0.01)$ and for $\mathrm{t} 10, \mathrm{c} 12$, by $88 \%$. Experiment 1 results showed that, if CLA has protective against cancer suggested by the available epidemiological studies, than CLA enrichment should be desirable. CLA supplementation with CLA increased milk volume production, altered it's composition, and reduced the energy requirements in relation to milk unity produced, allowing higher milk volumes, higher protein produced, particularly in environments where energy is restricted.. 


\section{INTRODUÇÃO}

Como os ácidos graxos constituem cerca de 90\% dos triglicerídeos e, estes, quase a totalidade dos lipídeos do leite e dos tecidos adiposos dos animais, o perfil de ácidos graxos é determinante nas propriedades físicas, químicas e organolépticas dos alimentos. A associação entre a ingestão de gordura e problemas de saúde colocoura no foco das atenções. Em especial, relacionourse a gordura de origem animal, mais saturada, e problemas de coração. Apesar do assunto ter sido, desde o início, polêmico, a condenação a gordura foi adotada com vigor. Isso foi facilitado pelo ímpeto de, através de uma medida simples combater um grave problema de saúde. A objetividade da proposta ("coma menos gordura para não morrer cedo") facilitou a aceitação pela população. Novos estudos têm demonstrado falhas nesta concepção simplista. Em especial, há a clara noção que tirar conclusões a respeito de gordura de maneira agregada implica em altas probabilidades de incorreções. Um bom exemplo é o caso dos ácidos graxos trans, que são associados epidemiologicamente a aumento de doenças coronarianas. Um estudo epidemiológico mostrou que há essa relação para fontes vegetais, mas não para gorduras de fonte animal. Fica claro que é necessário caminhar para um grau de desagregação maior, até chegar aos ácidos graxos isoladamente. Neste particular, nenhum exemplo é mais eloqüente do que o do ácido linoléico conjugado (CLA). Na verdade, existem diversos isômeros de CLA. Dois deles, todavia, tomaram nos últimos dez anos, lugar de destaque nas pesquisas de várias áreas. 
Um deles é o C18:2 Cis-9,Trans-11 (c9,t11), normalmente o mais abundante na natureza, e que tem forte efeito anti-carcinogênico e de modulação do sistema imune, como já comprovado em vários modelos animais. O outro isômero em destaque, é o C18:2 Trans-10, Cis-12 (t10,c12) que é um potente repartidor de nutrientes. Portanto são duas moléculas com pequenas diferenças de posição e geometria de ligação, mas com ações diversas e intensas no metabolismo animal, mesmo em quantidades reduzidas na dieta (0,1-1\% da MS). Isso ocorre pois estas moléculas interferem com processos básicos de metabolismo, como a inibição de substâncias que agem na região promotora de genes. Ainda para ilustrar a necessidade do estudo individual dos ácidos graxos vale a pena citar que, entre a proposta que a depressão da gordura do leite (DGL) seria devida aos ácidos graxos trans que inibiriam diretamente a síntese de gordura na glândula mamária até a identificação do t10,c12 (e ácidos graxos trans-10) como os agentes causais, passaram-se quase 30 anos. Prevaleceu durante esse tempo a teoria que DGL envolvia apenas o efeito da insulina na repartição de nutrientes. Apenas quando o perfil de ácidos graxos foi detalhadamente estudado, pode-se confirmar que a maior parte da DGL é fruto da inibição direta na glândula mamária.

Como CLA é um produto da biohidrogenação incompleta, alimentos de origem de ruminantes são as principais fontes de CLA na dieta humana. Assim, após anos de condenação a produtos bovinos e lácteos, a existência de um componente potencialmente tão benéfico pode ser a chance para uma nova percepção por parte dos consumidores e pela comunidade médica dos alimentos de origem animal. Suplementação de animais com CLA pode aumentar sua concentração no leite para produzir um "nutracêutico" (alimento com propriedades medicinais) que pode ser recompensado com um maior valor de mercado. A atividade metabólica do isômero t10,c12 pode ser utilizada para alterar a composição do leite. Como a composição do leite determina as necessidades de nutrientes e energia, as próprias exigências dos animais também podem ser influenciadas pela suplementação com CLA. Há, portanto, há uma gama de oportunidades oferecidas pelo uso das atividades metabólicas dos ácidos graxos que começa a ser explorada com o CLA. 
Os objetivos da primeira fase deste trabalho foram estabelecer as concentrações dos principais isômeros de CLA nas suas principais fontes e na dieta humana completa, ainda observando efeitos de diferentes raças e épocas de produção para leite e diferentes sistemas de produção e raça para carne bovina. Na segunda fase, procurourse estabelecer o efeito da suplementação de uma mistura de CLA, como sais de cálcio, na produção, composição e qualidade do leite, com ênfase para os teores de gordura e proteína e o perfil de ácidos graxos, incluindo o teor de CLA. 


\section{REVISÃO DE LITERATURA}

\subsection{Lipídeos nos alimentos para animais}

Nos vegetais, os triglicerídeos estão presentes principalmente nas sementes, enquanto que, nas folhas, os lipídeos se apresentam principalmente na forma de galactolipídeos, compostos de galactose, glicerol e ácidos graxos insaturados. Os galactolipídeos são típicos de folhas metabolicamente ativas, e diminuem com a idade da folha e com a redução da relação folha:caule. (Van Soest, 1994). Há grande falta de valores de ácidos graxos para forragens na literatura, especialmente no caso de tropicais. Bauchart et al. (1984) demonstraram que gramíneas temperadas continham de 1 a 3\% de ácidos graxos, sendo que os valores mais elevados foram observados na primavera e outono. O alfa-linolênico (C 18:3) representa entre 55-65\% do total de ácidos graxos. O’Kelly \& Reich (1976) mostraram que as forrageiras tropicais têm um perfil de ácidos graxos bastante diferente das de clima temperado. Esses autores demonstraram que algumas gramíneas tropicais, como o Panicum maximum cv. Tricoglume, têm como principal ácido graxo o C16:0 (30\%), ainda que as concentrações de C18:2 (28\%) e C18:3 $(23 \%)$ sejam também altas. Outras gramíneas (Paspalum distichum; Chloris gayana; Cenchrus ciliaris, Dichantium sericeum) têm valores elevados de C18:3 (34-36\%), mas também apresentam valores entre 24-25\% para C18:2 e C16:0. Por fim, esses autores apresentam valores para uma leguminosa (Macroptilium atropurpureum) que têm os maiores valores de C18:3 (42\%) e cerca de 19-20\% para C18:2 e C16:0. As forrageiras tropicais teriam também, segundo O’Kelly \& Reich (1976), valores de ácidos graxos totais significativamente mais elevados no verão do que no inverno, mas as diferenças são menores que as apresentadas por Bauchart et al. (1984) para temperadas. 
Valores para os ácidos graxos dos principais alimentos usados na nutrição de ruminantes podem ser observados na Tabela 1.

Tabela 1. Composição de ácidos graxos de alguns alimentos utilizados na nutrição de ruminantes.

\begin{tabular}{|c|c|c|c|c|c|c|c|c|}
\hline $\begin{array}{l}\text { Tipo de } \\
\text { Gordura }\end{array}$ & C14:0 & $\mathrm{C} 16: 0$ & C16:1 & C18:0 & C18:1 & C18:2 & C18:3 & $\begin{array}{l}\text { Outros } \\
\text { Ácidos } \\
\text { Graxos } \\
\end{array}$ \\
\hline Sais de cálcio ${ }^{4}$ & 1,3 & 48,7 & 1,1 & 4,1 & 36,5 & 7,8 & 0,3 & 0,2 \\
\hline $\begin{array}{c}\text { Sebo } \\
\text { hidrolisado }\end{array}$ & 2,4 & 39,7 & 0,7 & 42,7 & 10,9 & 1,0 & - & 2,6 \\
\hline Sebo & 3,0 & 24,5 & 3,7 & 19,3 & 40,9 & 3,2 & 0,7 & 4,9 \\
\hline Aves & 1,0 & 22,1 & 7,2 & 6,5 & 43,0 & 18,5 & 0,9 & 0,7 \\
\hline Óleo de Peixe ${ }^{1}$ & 8,0 & 15,1 & 10,5 & 3,8 & 14,5 & 2,2 & 1,5 & 44,5 \\
\hline Óleo de Peixe ${ }^{2}$ & 7,2 & 11,7 & 9,6 & 0,8 & 12,0 & 1,1 & 0,8 & 56,8 \\
\hline Peixe $^{5}$ & 4,3 & 25,4 & 16,3 & 5,2 & 15,3 & 2,5 & 0,3 & 30,7 \\
\hline Canola & - & 4,8 & 0,5 & 1,6 & 53,8 & 22,1 & 11,1 & 6,1 \\
\hline Milho & 0,0 & 10,9 & - & 1,8 & 24,2 & 58,0 & 0,7 & 4,4 \\
\hline Algodão & 0,8 & 22,7 & 0,8 & 2,3 & 17,0 & 51,5 & 0,2 & 4,7 \\
\hline Linhaça & - & 5,3 & - & 4,1 & 20,2 & 12,7 & 53,3 & 4,4 \\
\hline Palma & 1,0 & 43,5 & 0,3 & 4,3 & 36,6 & 9,1 & 0,2 & 5,0 \\
\hline Amendoim & 0,1 & 9,5 & 0,1 & 2,2 & 44,8 & 32,0 & - & 11,3 \\
\hline Cártamo ${ }^{3}$ & 0,1 & 6,2 & 0,4 & 2,2 & 11,7 & 74,1 & 0,4 & 4,9 \\
\hline Gergelim & - & 8,9 & 0,2 & 4,8 & 39,3 & 41,3 & 0,3 & 5,2 \\
\hline Soja & 0,1 & 10,3 & 0,2 & 3,8 & 22,8 & 51,0 & 6,8 & 5,0 \\
\hline Girassol & - & 5,4 & 0,2 & 3,5 & 45,3 & 39,8 & 0,2 & 5,6 \\
\hline Trevo & 1,5 & 6,5 & 2,5 & 0,5 & 6,6 & 18,5 & 60,7 & - \\
\hline $\begin{array}{l}\text { Gramínea } \\
\text { temperada }\end{array}$ & 1,1 & 16,0 & 2,5 & 2,0 & 3,4 & 13,2 & 61,3 & $<1$ \\
\hline $\begin{array}{c}\text { Dactylis } \\
\text { glomerata }\end{array}$ & 1.4 & 11,2 & 6,4 & 2,6 & - & 76,5 & - & \\
\hline
\end{tabular}

Fonte: NRC 2001; Van Soest, 1994; Maia et al., 1994.

1 Brevoortia tyrannus; 2 Salmão, 3 Carthamus tinctorius, 4 Óleo de palma, 5 Prochilodus scrofa (Curimbatá)

Pode-se observar um forte contraste entre as fontes animais, mais saturadas, e as vegetais, mais insaturadas. No caso das fontes vegetais, elas se destacam pelo conteúdo de ácidos graxos poliinsaturados, sendo que há grande variação entre as fontes na composição deste grupo de ácidos graxos. As fontes mais comuns de gordura em dietas de ruminantes no Brasil, os grãos de soja, de algodão e de milho, têm como principal ácido graxo o ácido 
linoléico, com a soja tendo ainda um dos valores mais elevados de ácido linolênico, cuja principal fonte é o óleo de linhaça.

\subsection{Composição em ácidos graxos no leite e nos tecidos animais}

\subsubsection{Leite bovino}

O perfil de ácidos graxos do leite caracteriza-se por conter desde ácido graxos com 4 carbonos até ácidos graxos de cadeia muito longa, com 26 carbonos, incluindo ácidos graxos de cadeia ramificada e diversos isômeros dos insaturados, alguns em concentrações bastante diminutas (Kramer et al., 1997). Há diferenças no perfil de ácidos graxos ao longo da lactação (Christie, 1981), especialmente afetado pela necessidade de mobilização de reservas lipídicas no início da lactação. Com relação ao efeito de raça, não há grande diferença entre os perfis de ácidos graxos (De Peters et al., 1995).

Na glândula mamária há intensa atividade lipogênica. A síntese de novo é feita a partir de acetato e do beta-hidroxibutirato (BHBA), sendo que este último contribuiria com cerca de $15 \%$ do carbono fixado como gordura (Chilliard et al., 2000). As enzimas chaves desta rota metabólica são duas: a acetil-CoA-carboxilase (ACC) e a sintetase de ácidos graxos (FAS). A primeira é responsável por transformar acetato em malonil-CoA e a FAS, por sua vez, catalisa os ciclos de condensação do malonil-CoA com acetil-CoA ou butiril-CoA, originados do metabolismo do acetato ou do BHBA. Os ácidos graxos com mais de 16 carbonos não são sintetizados pela glândula mamária de ruminantes, pois o sistema enzimático (Tioesterase I) de terminação dos ciclos de condensação da sintetase de ácidos graxos produz C14:0 e, predominantemente, C16:0 e a glândula mamária lactante, ao contrário de outros tecidos do ruminante, não é capaz de elongar de C16:0 para C18:0 (Chilliard et al., 2000).

É comum assumir que todo conteúdo de ácidos graxos com menos de 10 carbonos seja resultado da lipogênese mamária, através da síntese de novo, e que essa 
seria a mesma origem de metade dos ácidos graxos de 12 carbonos a 16 carbonos. A outra metade destes, e os ácidos graxos com mais de 18 carbonos, teriam origem exógena, oriundos da mobilização das reservas corporais ou de ácidos graxos absorvidos da dieta (Demeyer \& Doreau, 1999).

Segundo Hansen \& Knudsen (1987), a incorporação dos ácidos graxos sintetizados nos triglicerídeos (TGA) na glândula mamária é afetada pelo tipo e quantidade de ácidos graxos exógenos, sendo que ácido palmítico estimula a síntese e incorporação, enquanto esteárico e linoléico seriam inibitórios. Os efeitos de ácidos de cadeia longa na redução da lipogênese já estão bem estabelecidos, mas há grande diferença na intensidade de ação entre os ácidos graxos na inibição da lipogênese da glândula mamária.

$\mathrm{O}$ aspecto preponderante que afeta a composição de ácidos graxos exógenos disponíveis para a glândula mamária é a biohidrogenação promovida por algumas bactérias ruminais. Um resumo do processo de biohidrogenação no rúmen foi descrito por Harfoot \& Hazelwood (1988), no qual o ácido linoléico presente na dieta (C18:2 cis9, cis12) é isomerisado a cis9, trans11 (CLA) e, posteriormente, reduzido em duas etapas a C18:1 trans-11 e então a ácido esteárico (18:0). Todas essas conversões seriam realizadas, segundo esses autores, pelos grupos de bactérias A e B, mas apenas as do último grupo fariam a conversão de vaccênico (ou oléico) para esteárico. Embora seja essa a via principal de biohidrogenação, há outras que formam diferentes tipos de CLA e outros ácidos graxos monoinsaturados. A biohidrogenação é um obstáculo ao fornecimento de ácidos graxos insaturados para a deposição no tecido adiposo ou incorporação pela glândula mamária pois, em dietas convencionais, quase todo C18:2 e C18:3 são biohidrogenados A biohidrogenação ruminal, definida como o desaparecimento de linoléico e linolênico, costuma ser extensa. Em média, 80\% do linoléico e $92 \%$ do linolênico são saturados, valores próximos aos encontrados por Fellner et al. (1995) e Ferlay et al. (1993), respectivamente. O fato de o linoléico ser menos biohidrogenado pode ser devido a uma via metabólica diferente daquela usada para o linolênico, mas também por ele ser preferencialmente incorporado aos 
microrganismos (Harfoot \& Hazelwood, 1988). Fellner et al. (1995), todavia, comentam que parte do desaparecimento dos ácidos graxos poliinsaturados (AGPI), algumas vezes atribuídos a biohidrogenação, também pode ser devido à incorporação preferencial destes por microrganismos ruminais, portanto mostrando que a incorporação de ácidos graxos nos microrganismos é um complicador para a correta determinação da taxa de biohidrogenação dos ácidos graxos. A extensão da biohidroge nação também depende da natureza das dietas: com concentrado maior que $70 \%$, ela cai para $50 \%$ e $65 \%$, respectivamente para linoléico e linolênico. A queda no $\mathrm{pH}$ normalmente associada com este tipo de dieta reduz a lipólise, passo essencial para que ocorra a biohidrogenação (Chouinard et al., 1999). Beam et al. (2000) não observaram efeito na taxa de biohidrogenação na dieta oferecida a uma vaca ou o tempo após o fornecimento do alimento, mas sim para a fonte de lipídeos e a quantidade destes. Apesar disto ser não só devido ao efeito da biohidrogenação em si, mas da necessidade de lipólise anteriormente à biohidrogenação no caso dos lipídeos neutros, Beam et al. (2000) demonstraram uma forte relação $(\mathrm{R}=0.94)$ entre teor de linoléico in vitro e redução biohidrogenação, colocando-o como um importante fator que altera a chegada de lipídeos insaturados no duodeno.

Para evitar a biohidrogenação de ácidos graxos insaturados, são usados métodos de proteção dos ácidos graxos no rúmen. A saponificação dos ácidos graxos para formar sais de cálcio tem sido a maneira mais comum de proteção e funciona bastante satisfatoriamente com óleo de palma, com menos de $1 \%$ de dissociação em $\mathrm{pH}$ 6,5, e chegando a menos de $10 \%$ em pH 5,5 in vitro, baseado no pKa das fontes e calculada pela equação de Hendersom-Haselbach (Sukhija \& Palmquist, 1990). Neste mesmo trabalho, o sal de cálcio produzido com óleo de soja apresentou valores de $80 \%$ de dissociação, em função do menor pKa dos ácidos graxos insaturados. Outra forma de proteção, mais recente, é a reação de ácidos graxos com aminas primárias para produzir amino-acil graxos que resistem à biohidrogenação e aumentam a quantidade de AGPI na gordura do leite (Jenkins et al., 1996). Uma maneira de tentar fazer os ácidos graxos serem menos expostos à biohidrogenação no rúmen seria através da própria proteção 
pela planta (ou parte da planta) que os contêm (Chilliard et al., 2000). Independente de haver ou não proteção, um fato que ajuda no enriquecimento de AGPI é a inibição na taxa de biohidrogenação com o aumento na concentração de ácidos graxos na dieta (Beam et al., 2000). O uso de ionóforos e a redução do pH ruminal também reduzem a biohidrogenação (Demeyer \& Doreau, 1999).

Os ácidos graxos pré-formados advêm de ácidos graxos não esterificados (AGNE) ou de lipoproteínas ricas em TGA (quilomicron e lipoproteínas de muito baixa densidade, VLDL). A retirada de AGNE do sangue depende basicamente de sua concentração que, por sua vez, reflete a disponibilização de gordura corporal (Pethick \& Dunshea, 1993). Já no caso dos TGA, há necessidade da ação da lipoproteína lipase (LPL). Essa enzima se apresenta em alta atividade na glândula mamária e a absorção de TGA é bem correlacionada com sua concentração plasmática (Barber et al., 1997). A absorção de ácidos graxos de lipoproteínas de alta densidade (HDL) plasmáticas pela glândula mamária é baixa, o que ajuda a explicar o baixo conteúdo de AGPI no leite (Demeyer \& Doreau, 1999). Para compensar esse fato e não comprometer a fluidez do leite, a atividade da Delta-9-dessaturase é elevada na glândula mamária (Kinsela et al., 1972), particularmente transformando o C18:0 em C18:1, sendo que outros ácidos graxos de cadeia média podem também ser insaturados (Demeyer \& Doreau, 1999). Todavia, a Delta-9-dessaturase tem pouca atividade sobre ácidos com menos de 18 carbonos, motivo pela qual a maioria dos ácidos graxos de cadeia curta (AGCC) são saturados (Chilliard et al., 2000). Já no caso do esteárico, cerca de $40 \%$ do que é absorvido pela glândula mamária é reduzido para oléico, portanto mais de $50 \%$ do oléico podendo ser originado por atividade desta enzima (Enjalbert et al., 1998). Uma elevada presença de ácidos graxos trans C18:1 é típico da gordura do leite. Além de gerados pela ação da Delta-9-dessaturase, eles provêm da biohidrogenação parcial dos AGPI e, como são mais difíceis de hidrogenar, os isômeros trans acabam acumulando no rúmen (Van Soest, 1994). O isômero de posição preponderante no leite é o C18:1 trans-11 (Precht \& Molkentien, 1997) representando mais de $80 \%$ dos transmonoenos no rúmen, mas apenas 40-60\% destes na gordura do leite (Griinari et al., 1997a), resultado de sua 
metabolização na glândula mamária, especialmente na produção do CLA c9,t11. Há trabalhos mostrando relação entre o c9,t11 e o C18:1 trans-11 (Lin et al., 1995; Jiang et al., 1996, Kaulscher et al., 1998).

Tabela 2. Perfis de ácidos graxos selecionados do leite de alguns experimentos com variados tratamentos.

\begin{tabular}{|c|c|c|c|c|c|c|c|c|c|c|}
\hline & $\begin{array}{l}\text { Conv. } \\
\text { Brasil }^{1}\end{array}$ & $\begin{array}{l}\text { Grão } \\
\text { Soja }{ }^{1}\end{array}$ & $\begin{array}{l}\text { Óleo de } \\
\text { Soja }^{1}\end{array}$ & Pasto $^{2}$ & $\begin{array}{c}\text { Ração+ } \\
\text { Pasto }^{2}\end{array}$ & $\begin{array}{l}\text { Pasto + } \\
\text { Ração }^{3}\end{array}$ & $\begin{array}{c}\text { Alta } \\
\text { Fibra }^{4}\end{array}$ & $\begin{array}{l}\text { Baixa } \\
\text { Fibra }^{4}\end{array}$ & $\begin{array}{l}\text { Conv. } \\
\text { EUA }^{5}\end{array}$ & $\begin{array}{l}\text { Óleo de } \\
\text { Peixe }^{5}\end{array}$ \\
\hline$\overline{\mathrm{C} 4: 0}$ & 5.8 & 5.2 & 4.8 & $\mathrm{ND}^{6}$ & ND & ND & ND & ND & 3.2 & 2.9 \\
\hline C6:0 & 3.6 & 3 & 2.7 & ND & ND & ND & ND & ND & 2.0 & 1.5 \\
\hline C8:0 & 1.5 & 1.2 & 1.1 & ND & ND & ND & ND & ND & 1.3 & 0.8 \\
\hline C10:0 & 2.9 & 2.2 & 1.2 & 1.8 & 2.1 & 2.5 & ND & ND & 3.1 & 1.9 \\
\hline C12:0 & 2.9 & 2.2 & 1.8 & 2.3 & 2.6 & 3.2 & ND & ND & 3.7 & 2.3 \\
\hline C14:0 & 8.5 & 7 & 6.1 & 9.1 & 9.4 & 11.3 & 12.4 & 12.8 & 11.3 & 9.3 \\
\hline C16:0 & 22.1 & 19.4 & 16.1 & 25.1 & 24.7 & 29.0 & 32.2 & 29.1 & 27.1 & 26.6 \\
\hline C16:1 & 1 & 0.9 & 0.9 & 1.8 & 1.2 & 2.1 & 2.1 & 2.2 & 1.4 & 3.3 \\
\hline C18:0 & 8.2 & 11.8 & 11.1 & 12.1 & 15.2 & 10.8 & 12 & 10 & 9.4 & 4.0 \\
\hline $\begin{array}{l}\text { C18:1 } \\
\text { total }\end{array}$ & 26 & 32.1 & 31.5 & 32.6 & 31.4 & 24.9 & 23.6 & 22.4 & 22.5 & 29.0 \\
\hline $\begin{array}{l}\mathrm{C} 18: 2 \\
\mathrm{c} 9 \mathrm{c} 12\end{array}$ & 1.6 & 2.1 & 1.3 & 1.4 & 4.3 & 2.3 & 4.1 & 5.2 & 3.1 & 2.4 \\
\hline C18:3 & 0.1 & 0.1 & 0.1 & 2.0 & 0.8 & 0.7 & 0.7 & 0.61 & 0.5 & 0.6 \\
\hline CLA & 0.2 & 0.2 & 0.4 & 2.2 & 0.4 & 0.2 & ND & ND & 0.7 & 2.1 \\
\hline
\end{tabular}

Na Tabela 2 , são apresentados valores do perfil de ácidos graxos para diferentes situações. A maioria dos valores é para vacas holandesas puras, exceto para os dados do Brasil (Santos et al., 2000), que são de vacas 7/8 Holandês X Nelore. A inclusão de soja integral ou óleo de soja, que representou um aumento de 3\% para 7\% na gordura na MS da dieta, aumentou os ácidos graxos de cadeia longa (AGCL), mas com diminuição discreta dos ácidos graxos de cadeia curta (AGCC). O tratamento com grão é mais insaturado, o que está de acordo com a maior quantidade de lipídeos e a menor exposição dos ácidos graxos ingeridos ao meio ruminal. Comparando os resultados do pasto exclusivo com o tratamento com $1 / 3$ de pastagem e $2 / 3$ de ração, ambos de 
Dhiman et al., (1999), pode-se observar uma redução no C18:0 e grande aumento dos AGPI com a inclusão de concentrado devido à menor biohidrogenação ruminal em dietas com mais concentrado. Esse mesmo efeito pode ser observado na comparação dos perfis de ácido graxo de alta e baixa fibra (Kalscheur et al., 1997). Nas duas últimas colunas, há perfis de ácidos graxos de uma típica dieta americana para vacas de alta produção (controle) e o tratamento com $3 \%$ de óleo de peixe extraído de Donovan et al. (2000), que mostra como o óleo de peixe altera radicalmente a composição em ácidos graxos do leite.

\subsubsection{Bovinos de corte}

Normalmente, os lipídeos no músculo se apresentam na maioria como triglicerídeos (80-90\%), até $20 \%$ como fosfolipídios e menos de 3\% como éster de colesterol e ácidos graxos não esterificados (Rule et al., 1995). No tecido adiposo, há menor participação dos fosfolipídios (Lawrence \& Fowler, 1997). A composição em ácidos graxos componentes nos tecidos de bovinos sofre, da mesma maneira que o leite, grande influência da ação da biohidrogenação ruminal nos ácidos graxos da dieta, razão da menor presença de ácidos graxos insaturados nos ruminantes (Christie, 1981). Todavia, quando a ingestão de ácidos graxos insaturados é muito grande, a capacidade dos microrganismos do rúmen em biohidrogenar pode ser excedida, ocorrendo uma maior absorção intestinal de ácidos graxos insaturados. Essa seria a explicação para a sazonalidade encontrada na relação ácidos graxos saturados:insaturados (AGS:AGI) no tecido adiposo de bovinos e ovinos em países de clima temperado (Lawrence \& Fowler, 1997), uma vez que as pastagens jovens temperadas têm quantidades muito grandes de ácidos graxos poliinsaturados (Bauchart et al., 1984). De maneira semelhante ao leite, o principal isômero da série C18:1 trans é o trans-11 (Dermeyer \& Doreau, 1999).

A composição de cada depósito de gordura vai depender da dieta do animal e da necessidade de uso das reservas em cada momento de sua vida. Isso é afetado, também, por alterações nas intensidades das taxas de deposição de gordura que mudam de 
depósitos de gordura interna (perirenal, omental e de descarte) para a externa (Ingle et al., 1972) com o tempo. Em geral, todavia, acredita-se que os efeitos da dieta na alteração do perfil lipídico são maiores na gordura subcutânea do que na intramuscular (De Smet et al., 2000), como demonstrada pela maior atividade da lipoproteína lipase do tecido subcutâneo em novilhos de cruzamentos compostos em relação à atividade desta enzima em depósitos omental e perirenal, internos (Sprinkle et al., 1998). A atividade da lipoproteína lipase serve mais como indicadora de atividade lipogênica, mas a síntese de novo no tecido adiposo de bovinos é que seria mais determinante na composição em ácidos graxos (Rule et al., 1995). Na lipogênese do tecido adiposo, normalmente o palmitato (C16:0) é sintetizado, podendo ser elongado a estearato (C18:0) e este dessaturado a oléico (C18:1), mas elongações e dessaturações adicionais não ocorrem por falta dos sistemas enzimáticos necessários em vertebrados (Christie, 1981). Para mostrar a importância da lipogênese endógena, é ilustrativo o fato do perfil de ácidos graxos recém produzido em incubações de curto período do tecido adiposo se aproximar do perfil do tecido adiposo em dietas usuais de ruminantes, com baixos ( 3\% MS) teores de gordura (Pothoven et al., 1974).

É comum considerar que o nível de saturação aumenta dos locais mais externos (depósito subcutâneo) para os mais internos para animais de vários genótipos (Webb et al., 1998). Uma das hipóteses para explicar esse fato estaria ligada às diferenças de temperatura nos diferentes sítios e à necessidade dos depósitos subcutâneos terem um ponto de fusão menor dos lipídeos, uma vez que eles são expostos à temperaturas mais baixas que os demais (Lawrence \& Fowler, 1997). Isso talvez não ocorra desta maneira em países tropicais. Uma análise da Tabela 3 demonstra que essa generalização se aplica bem à comparação do depósito subcutâneo com o perirenal, mas que haveria pouca diferença entre subcutâneo e intramuscular com relação à insaturação. 
Tabela 3. Comparação da composição dos principais ácidos graxos dos vários depósitos lipídicos em bovinos.

\begin{tabular}{ccccc}
\hline Depósito & \multicolumn{4}{c}{ Ácido Graxo $(\mathrm{g} / 100 \mathrm{~g})$} \\
\hline & $\mathrm{C} 16: 0$ & $\mathrm{C} 18: 0$ & $\mathrm{C} 18: 1$ & $\mathrm{C} 18: 2$ \\
Subcutâneo & $25-28$ & $10-14$ & $38-52$ & $2-3$ \\
Perirenal & $25-31$ & $18-26$ & $34-36$ & $2-4$ \\
Intramuscular & $24-27$ & $13-14$ & $38-47$ & $3-4$ \\
\hline \multicolumn{2}{l}{ Fonte: Adaptado de Rule et al., 1995}
\end{tabular}

Essa análise está de acordo com a comparação dos valores dos ácidos graxos obtidos por Webb et al. (1998) para gordura intramuscular e subcutânea são semelhantes.

Em amostras compradas no varejo no Reino Unido, o valor de gordura intramuscular para amostras de carne bovina foi de 3,8\% (Enser et al., 1996). Já bovinos Belgian Blue com musculatura dupla apresentaram menos de $1 \%$ de gordura intramuscular (7,6 a 9,9 mg gordura/grama) e uma elevada relação AGPI:AGS para ruminantes de 0,39 em amostras de Longissimus dorsi (De Smet et al., 2000). Apesar dos baixos valores para gordura intramuscular, o grupo de animais submetidos a um nível inferior de energia apresentou significativamente mais gordura neste local. Os valores médios para AGS, AGMI e AGPI foram 46\%, 36\% e 18\%, portanto a composição do Longissimus dorsi de touros bastante magros (13\% de gordura corporal) é altamente insaturado e se aproxima daquela encontrada para porcos. Nas dietas com mais energia, houve aumento de MUFA em detrimento de AGPI, mas isso deve ter ocorrido, em parte, pela presença de sebo animal na dieta alta em energia.

Há diferença para diferentes cortes (Webb et al., 1998) quanto ao perfil de ácidos graxos. Enser et al., (1998) observaram que o Longissimus dorsi apresentava valores menores de AGPI, tanto para teor como quantidade, em relação a triceps brachi, gluteobiceps e glutes medius.

Animais Bos indicus apresentaram perfil de ácidos graxos subcutâneo menos saturados que animais da raça Bos taurus (Huerta-Leidenz et al., 1993). Essa diferença repete-se para bezerros nascidos de touros ou mães Bos indicus em comparação a 
bezerros de touros ou mães Bos taurus (Huerta-Leidenz et al., 1996). Há, também, grande diferença entre raças quanto à localização da gordura corporal. Animais com menores exigências de mantença podem ter uma maior partição da energia metabolizável para deposição de gordura subcutânea, conforme determinado por Sprinkle et al. (1998). Segundo esses autores, os animais com maiores exigências de mantença costumam ter, relativamente, maiores depósitos internos de gordura, que são mais fáceis de serem mobilizados. Hornick et al. (1998) observaram aumento na proporção de gordura subcutânea em detrimento da intramuscular em animais em ganho compensatório e os animais com os períodos mais longos teriam o perfil de ácidos graxos com menos AGS, mas o que pode ser um efeito de idade e não da compensação de ganho.

De acordo com Rule et al. (1995), forragens teriam maiores proporções de C16:0 e C18:3 e proporções menores de C18:1 e C18:2 em relação a concentrados. Animais alimentados com forragens tinham maiores concentrações de AGS e AGPI devido a maiores concentrações de ácido esteárico, linoléico e linolênico (Williams et al., 1983; Mandell et al., 1997; Marmer et al., 1984). Também Duckett et al. (1993), comparando diversos sistemas de produção, encontraram valores de esteárico mais elevado para animais que pastejaram por 10 meses em pastagens nativas antes de serem confinados em relação à desmama antecipada (3,5 meses), normal (7,9 meses), pastejo de trigo por cerca de 3 meses após desmama normal e pastejo nativo por 68 dias. Animais alimentados com pasto tem maior relação n-3/n-6 do que aqueles que consomem grão, pois as pastagens temperadas possuem maiores teores de alfa-linolênico (n-3) e, os grãos, de linoléico (n-6) (Enser et al., 1998; Nurnberg et al., 1998). Dietas com concentrado ajudam a diminuir o pH ruminal, o que reduz a lipólise e a biohidrogenação (Demeyer \& Doreau, 1999). Portanto, deve-se esperar que dietas com grãos produzam animais com perfil lipídico mais insaturado. A alimentação com grão aumentou o teor de ácido oléico e AGMI da gordura intramuscular (Williams et al., 1983; Mandell et al., 1997). Contrário a isso, Enser et al., (1998), comparando novilhos terminados a pasto com touros terminados com dietas à base de feno de cevada e concentrado peletizado de 
cevada e farelo de soja (4:1), obtiveram para Longissimus dorsi maior teor de oléico nos animais que pastejaram (35\% X 30\%). Os dados para AGPI estão mais de acordo com dados de literatura: para linoléico que foi maior nos confinados $(0,05 \%$ X 0,02\%) e os alfa-linolênico, da série Omega-3 foram maiores para os animais a pasto $(1,23 \% \mathrm{X}$ 0,52). Os novilhos a pasto apresentaram relação poliinsaturados:saturados quase 3 vezes menor do que os touros alimentados com concentrado. As diferenças nas porcentagens entre Longissimus dorsi, triceps brachi, gluteobiceps e glutes medius foram relativamente pequenas e os efeitos dos sistemas de produção foram bastante consistentes entre eles. Nurnberg et al. (1998) apresentam dados que mostram o dobro da concentração dos ácidos graxos n-3 para animais totalmente produzidos a pasto ou só terminados confinados contra aqueles totalmente confinados, apesar de que estes últimos tinham maiores teores de oléico (43\% x 38\%), o oposto ao obtido por Enser et al. (1998). Outro dado conflitante com a literatura é o valor de linoléico, menor para os animais totalmente confinados $(0,5 \times 1,1 \%)$.

Pelas supostas implicações positivas dos ácidos graxos n 3 na saúde humana, a maior concentração normalmente encontrada seria uma vantagem da produção de animais a pasto. A transferência dessa conclusão para os animais a pasto em países tropicais, em função da grande diferença de perfil de ácidos graxos entre forrageiras tropicais e temperadas, é prematura. Ainda que se repita isso nos países tropicais, devese, todavia, levar em conta que o aumento de poliinsaturados pode resultar em eventuais problemas de "flavour" e maior predisposição para rancificação desta carne. (Rule et al., 1995; Nurnberg et al., 1998).

A idade dos animais está relacionada com o perfil de ácidos graxos pois, com o tempo, os adipócitos diminuem a velocidade de aumento de diâmetro, aumentando a importância relativa da gota lipídica em relação à membrana, onde se concentram os ácidos graxos mais insaturados. Como os AGPI estão principalmente relacionados com a fração de fosfolipídios e a proporção destes declina com o avançar do tempo de confinamento, o perfil de ácidos graxos vai ficando menos insaturado (Duckett et al., 1993). Aumento nos AGS e diminuição dos AGPI com o tempo foi demonstrado em 
carneiros que, de 50 a 180 dias, tiveram uma grande redução de 18:2 e um aumento de ácidos graxos saturados que compensou essa diminuição (Nurnberg et al., 1998). Em um primeiro momento, todavia, há grandes aumentos dos insaturados e redução de saturados como demonstrado no trabalho de Huerta-Leidenz et al. (1996), em que à medida que os bezerros ficavam mais velhos houve aumento de ácidos graxos insaturados, principalmente pelo aumento dos monoinsaturados.

O tempo que o animal é colocado sob alimentação de produção, como em um confinamento, normalmente, faz haver um aumento de ácidos graxos monoinsaturados (AGMI), devido ao depósito de oléico na fração dos triglicerídeos, o que indicaria alterações na biohidrogenação ruminal ou na atividade da dessaturase com o tempo de alimentação, como observado por Duckett et al. (2000).

A alteração no perfil dos ácidos graxos dos animais também está relacionada com o aumento de conteúdo de gordura corporal, ou seja, quanto maior a gordura corporal maior a relação AGS:AGI (Marmer et al., 1984, De Smet et al., 2000, Webb et al., 1998). Essa seria a razão pela qual fêmeas teriam mais gordura corporal e portando um relação saturado:insaturado mais elevada (MalautAduli et al., 1998). Esses efeitos são explicados da mesma maneira que o fator idade.

\subsubsection{Suínos e Frango}

A composição em ácidos graxos de monogástricos reflete fortemente aquela da dieta, uma vez que eles são ingeridos e passam pelo trato-gastrintestinal destes animais praticamente inalterados (Rule et al., 1995). Dessa forma, alterações no perfil lipídico destes animais são possíveis através da alimentação enriquecida com os ácidos graxos de nosso interesse (Lawrence \& Fowler, 1997). Entretanto, há limites na inclusão de ácidos graxos na dieta, como no caso de suínos, em que o valor crítico de inclusão de ácido linoléico na dieta é de 0,035 MJ/MJ de energia digestível (Prescott \& Wood, 1988). Valores superiores a estes podem alterar o ponto de fusão da gordura subcutânea, interferindo negativamente na qualidade da carcaça. 
O tecido adiposo das aves não sintetiza quantias substanciais de gordura, sendo, em última análise, dependente dos ácidos graxos de origem da digestão ou da síntese no fígado, o que justifica o tecido adiposo das aves raramente ocorrer longe de capilares sanguiíneos e ser bastante vascularizado.

Pode haver outros fatores dietéticos que interfiram na relação ácidos graxos saturados:insaturados, como a concentração de cobre na dieta. O cobre, por aumentar a atividade das desaturases dos tecidos, pode diminuir essa relação (Lawrence \& Fowler, 1997)

Em suínos a meia vida de ácidos graxos é de cerca de 180 dias, portanto, há cerca de 50\% de chance de encontrarmos ácidos graxos depositados no início de sua vida (Enser et al., 1996)

Abaixo (Tabela 4) seguem alguns exemplos de perfis de ácidos graxos da gordura de alguns locais de ocorrência em suínos e frangos:

Tabela 4. Perfis de ácidos graxos de suínos na gordura sub-cutânea, de carne magra, do músculo latissimus e da gordura de abdominal, da coxa e do peito de frangos.

\begin{tabular}{ccccccccc}
\hline Ácido & \multicolumn{3}{c}{ Suíno } & \multicolumn{4}{c}{ Frango } \\
Graxo & Sub-cutânea & Longissimus & Latissimus & Abdominal & Coxa & Peito \\
\hline C14:0 & 1.8 & 1.3 & 1.0 & 1.0 & & 0.4 & 0.3 & 0.3 \\
C16:0 & 30.6 & 25.7 & 21.8 & 20.5 & 15.8 & 15.0 & 14.6 & 14.7 \\
C16:1 & 1.9 & 5.7 & 2.7 & 2.0 & 1.6 & NR & NR & NR \\
C18:0 & 12.9 & 13.2 & 12.4 & 12.8 & 6.1 & 5.2 & 7.7 & 7.6 \\
C18:1 & 25.8 & 42.2 & 35.9 & 36.0 & 33.4 & 24.9 & 19.4 & 17.4 \\
C18:2 & 16.7 & 10.1 & 12.0 & 22.3 & 39.0 & 26.9 & 31.4 & 27.0 \\
C18:3 & NR & 1.5 & NR & 1.3 & 0.8 & 0.4 & 0.5 & 0.4 \\
C 20:4 & 0.2 & 0.3 & 1.5 & NR & 0.4 & 0.1 & 3.5 & 4.9 \\
Referências & 1 & 3 & 1 & 2 & 4 & 5 & 5 & 5 \\
\hline Referências: 1. Thiel-Cooper et al., 2001; 2. Ramsay et al., 2001; 3. Smith et al., 1996; 4. Sanz et al., \\
2000; 5. Crespo \& Esteve-Garcia, 2001.
\end{tabular}

Com relação às informações sobre a origem dos dados de suínos, temos que os valores de ThielCooper et al. (2001) são do tratamento controle com dietas à base de milho e farelo de soja de porcos castrados (Yorkshire $\mathrm{X}$ Landrace $\mathrm{X}$ Duroc $\mathrm{X}$ Hampshire), abatidos com $116 \mathrm{~kg}$ de Peso Vivo. Também foi usado o tratamento 
controle do experimento de Ramsay et al. (2001) em que foram usados porcos de cruzamento Yorkshire X Landrace, metade fêmeas e metade machos. Os animais foram abatidos com $55 \mathrm{~kg}$ de Peso Vivo após receberem, desde os $20 \mathrm{~kg} \mathrm{PV}$, dieta à base de milho, farelo de soja, soro de leite seco $(2,0 \%)$ e óleo de milho $(2,0 \%)$. Por fim, o último perfil de suínos apresentado foi extraído do trabalho de Smith et al. (1996), que foi determinado em porcos que recebiam dieta de sorgo, farelo de soja e amido de milho (dieta controle), e que tiveram amostras da gordura sub-cutânea extraída no abate da área sobre a primeira vértebra cranial. No caso dos dados de frango, foram usados dados dos trabalhos de Crespo \& Esteve-Garcia (2001) e Sanz et al. (2000). No primeiro, Sanz et al. (2000) usaram frangos fêmeas, da linhagem Hybro G que, a partir de 21 dias, receberam dietas basais com trigo, milho, farelo de soja e o tratamento mostrado na

tabela, com óleo de girassol. No trabalho de Crespo \& Esteve-Garcia (2001), frangos da linhagem Ross receberam de 21-42 e 21-49 dias, para machos e fêmeas, respectivamente, dietas experimentais à base de trigo, glutenose e farelo de soja e, no caso, foi escolhido o tratamento complementado pelo óleo de girassol (10\% da MS).

\subsection{O ácido linoléico conjugado}

Apesar de referido como uma única molécula, o ácido linoléico conjugado (CLA) é um grupo de isômeros de posição e geométricos com duplas ligações conjugadas (separadas apenas por uma ligação simples carbono-carbono). Há 56 possíveis isômeros geométricos e de posição do CLA (Yurawecz et al., 2001). Um isômero de CLA foi identificado como um potente anticarcinogênico natural (Pariza \& Ha, 1990; Ip et al., 1991; Ip et al., 1994;), enquanto outro como um agente repartidor de nutrientes muito efetivo (McGuire et al., 1997, Park et al., 1997; Dunshea et al., 1998). O isômero mais relacionado à atividade anticarcinogênica é o C18:2 Cis-9, Trans-11 (c9, t11) e o implicado no metabolismo de gordura é o C18:2 Trans-10, Cis-12 (t10, c12). Estudos usando diferentes modelos animais relacionaram o CLA a vários outros efeitos positivos que poderiam favorecer à saúde humana, incluindo a redução na aterosclerose, prevenção e tratamento do diabetes mellitus não-dependente da insulina, propriedades 
antitrombóticas e efeitos imuno-estimulatórios. Para maiores detalhes sobre estes efeitos, é sugerida a revisão de Sebedio et al. (1999).

\subsubsection{Produção do CLA}

O CLA é formado no rúmen pela biohidrogenação incompleta de ácidos graxos poliinsaturados da dieta, mas também endogenamente, através da dessaturação do ácido graxo C18:1 trans11 por uma enzima presente na glândula mamária e tecido adiposo (Bauman \& Grinari, 1999; Corl et al., 2000), a Delta-9-dessaturase. Como o C18:1 trans11 também é produzido através da biohidrogenação, este processo é o grande responsável pela existência de CLA e sua predominância em ruminantes explica a razão de serem seus produtos serem as maiores fontes de CLA.

\begin{tabular}{|c|c|c|}
\hline $\begin{array}{c}\text { Cis 9,Cis } 12 \text { C18:2 } \\
\text { (ácido linoléico) } \\
\downarrow \text { Isomerase } \\
\text { Cis 9,Trans } 11 \text { C18:2 } \\
\text { (CLA) } \\
\downarrow \text { Redutase } \\
\text { Trans } 11 \text { C18:1 } \\
\text { (ácido vaccênico) } \\
\downarrow \text { Redutase } \\
\text { C18:0 } \\
\text { (ácido esteárico) }\end{array}$ & $\rightarrow$ & $\begin{array}{c}\text { CIS 9,CIS 12 C18:2 } \\
\text { (ácido linoléico) } \\
\text { CIS 9,TRANS 11 C18:2 } \\
\text { (CLA) } \\
\uparrow \Delta^{9} \text { Desaturase } \\
\text { TRANS 11 C18:1 } \\
\text { (ácido vaccênico) } \\
\Delta^{9} \text { Desaturase } \\
\text { C18:0 C18:1 CIS } 9 \\
\text { (ác. esteárico) } \quad \text { (ác. oléico) }\end{array}$ \\
\hline
\end{tabular}

Figura 1 - Esquema da produção de CLA em bovinos. Os passos do quadro à esquerda, ocorrem no rúmen e os da direita, na glândula mamária ou tecido adiposo (letras das configurações em maiúsculas). Adaptado de Bauman \& Griinari (2001). 
Na biohidrogenação, descrita por Harfoot \& Hazelwood (1988), depois da ação da linoleato isomerase (EC 5.2.1.5) é formada a ligação conjugada entre os carbonos 9 e 11, sendo esta última insaturação de configuração trans. Em seguida, ocorrem as reduções das ligações cis, até C18:1 trans 11, que podem ser adicionalmente reduzidas até C18:0 (Figura 1).

Na Figura 1, no lugar do C18:2 cis-9, cis-12, poderia estar o C18:3 cis-9, cis-12, cis-15 (alfa-linolênico) ou cis6, cis9, cis12 (gama-linolênico). Nas etapas de redução, todas as ligações cis (cis-9 para 18:2 e cis-9 ou cis-6 para alfa-linolênico e gamalinolênico) são biohidrogenadas, portanto, o C18:1 trans-11 é intermediário comum entre esses ácidos graxos. A redução do C18:1 trans 11 para C18:0 parece ser o passo limitante da biohidrogenação e, portanto, este ácido graxo costuma acumular no rúmen (Van Soest, 1994). Ele pode ser absorvido no intestino e levado para o tecido adiposo ou glândula mamária, onde pode tornar-se c9,t11.

Corl et al. (2000) demonstraram que a infusão de 12,5 g/dia do ácido graxo C18:1 trans11 no abomaso de vacas em lactação resultou em um aumento de $40 \%$ do conteúdo de CLA na gordura do leite, indicando que as vacas foram capazes de sintetizar endogenamente o CLA. Eles estimaram que cerca de 78\% do CLA na gordura do leite teria como origem a ação da Delta-9-dessaturase. Esse valor é menor, mas próximo ao encontrado por Lock \& Garnsworthy (2001), cuja média entre 4 tratamentos, com todas as combinações de concentrações de C18:2 e C18:3 alta e baixa, foi de $85 \%$ do CLA de origem endógena. Este trabalho revelou que o tratamento em que as vacas recebiam altas doses de ambos ácidos graxos, apresentaram valores significativamente mais elevados de c9,t11 $(1,1 \%)$ do que os demais tratamentos que ficaram entre 0,8 a 0,9\%. Portanto, ambos afetam a quantidade de CLA que pode ser sintetizado, através da ação de bactérias no rúmen, biohidrogenando-os, e da glândula mamária, pela ação da Delta-9-dessaturase.

A produção de CLA é maior em animais pastejando, mas dificilmente ultrapassa os $20 \mathrm{mg} / \mathrm{g}$ gordura, mas dietas à base de feno e grãos podem ter o valor de CLA, ultrapassando esse valor por suplementos contendo ácido linoléico (vide item 2.3.2). 
Segundo Kim et al. (2000), que avaliaram a produção de CLA por Butyrivibrio fibrisolvens A38 em cultura, essas observações são consistentes com o fato de $B$. fibrisolvens ser uma bactéria digestora de hemicelulose encontrada em grande número quando os animais são alimentados com forragens ou feno. Além disso, o ácido linoléico provoca a inibição da biohidrogenação e o aumento de produção de CLA pela Butyrivibrio fibrisolvens A38. Os resultados de Kim et al. (2000) indicaram que a isomerase é uma enzima ligada à membrana e, como as membranas mantiveram a capacidade de converter ácido linoléico em CLA no meio de cultura, há grandes possibilidades disto ocorrer também no rúmen, pois esta bactéria apresenta lise quando chega à fase estacionária. Assim sendo, segundo estes autores, o fluxo de CLA do rúmen pode ser dependente de inativação bacteriana, morte ou lise decorrente da concentração de ácido linoléico. Há condições que podem reduzir ainda mais os passos da biohidrogenação. LeDoux et al. (2002) comentam que teores de fibra baixos reduziriam o útlimo passo da biohidrogenação com consequente acumulação de C18:1 trans11.

Outras bactérias são capazes de produzir CLA mais eficientemente que $B$. fibrisolvens. Stanton et al. (2001) obtiveram conversão de ácido linoléico em CLA de até $65 \%$ com Bifidobacterium (sendo B. breve e B. dentium as mais eficientes) quando o ácido linoléico variou de $200-1000 \mu \mathrm{g} / \mathrm{ml}$ no meio de cultura.

Há produção de CLA em humanos por ação da Delta-9 dessaturase em 18:1 t7 e 18:1 t 11 (Salminen et al., 1998). Neste caso, o isômero de interesse é o C18:2 cis9, trans11, que é o CLA encontrado em maior proporção na gordura do leite e carne de ruminantes.

O CLA também pode ser sinteticamente produzido e métodos diferentes de produção levam a produtos com diferentes composições em seus isômeros (Chouirnad et al., 2000). Há aqueles feitos a partir da desidratação do óleo de rícino, de tratamentos com álcalis fortes de óleo de girassol à altas pressões e de óleo de cártamo com solução concentrada de hidróxido de potássio em propileno glicol. Este último apresenta a maior concentração de CLA (90\%), com proporções de c/t 9,11 e c/t 10,12 em uma relação quase 1:1 e foram usados nos experimentos do grupo de Wisconsin, os precursores do 
estudo do CLA. Os dois primeiros, com 60\% de CLA, com a composição variando entre 24\%-40\% de c/t 9,11, de 14\%-37\% de c/t 8,10 e de até 28\% de c/t 10,12 foram usados pelos grupos de Cornell, Idaho e do LNCA/ESALQ.

\subsubsection{Variação da concentração do CLA no leite e tecidos}

Como todos os ácidos graxos poliinsaturados, o CLA tende a ser menos direcionado para tecidos de depósito e mais para fosfolipídeos de membranas (Christie, 1981). No caso dos isômeros de CLA, há diferença entre os isômeros c9,t11 e t10,c12, sendo que o segundo é mais metabolizado e, portanto, encontrado em menores concentrações nos tecidos. Todavia, a forma na qual o CLA irá se acumular (lipídeos neutros ou fosfolipídeos) depende, também, do estado fisiológico do animal quando exposto ao CLA (Bauman, comunicação pessoal).

Tabela 5. Valores médios encotrados em alguns alimentos

\begin{tabular}{lll}
\hline Alimento & Média (mg/g gordura) & Erro Padrão da Média \\
\hline Leite & 5,5 & 0,30 \\
Iogurte & 4,8 & 0,26 \\
Carne Bovina & 4,3 & 0,13 \\
Carne Ovina & 5,6 & 0,29 \\
Carne Suína & 0,6 & 0,06 \\
Carne de Frango & 0,9 & 0.02 \\
Carne Peixe & 0,3 & 0,05 \\
\hline
\end{tabular}

Fonte: Chin et al, 1992

É possível aumentar o teor de CLA no leite através manipulação da dieta (Griinari et al., 1998). Há diferentes estratégias para aumento da concentração do CLA no leite, incluindo o uso de certas fontes de gordura poliinsaturadas (óleos vegetais) e suplementação da dieta com CLA para as vacas. Os limites para essa estratégia não são conhecidos, mas a grande variação determinada para vacas consumindo diferentes dietas (Jahreis et al., 1997; Dhiman et al., 1999) indica haver grande potencial. Isso parece verdadeiro, ainda que cerca de $80 \%$ do CLA na gordura do leite sejam derivados da 
atividade da Delta-9-dessaturase na glândula mamária (Corl et al., 2000; Lock e Garnsworthy, 2001). Kelsey et al., (2001) observaram um comportamento bastante consistente de animal para produção de CLA, com algumas vacas produzindo sempre mais CLA que outras e a relação C14:0/C14:1 mostrou variação de 2 até 3 vezes entre indivíduos dentro de dietas para alta ou baixa produção de CLA. Essa foi a mesma faixa observada para os valores de CLA. Estes dados são corroborados por Kelly et al. (1998) e Lock \& Garnsworthy (2001). Certamente, o controle da atividade desta enzima é outro ponto que pode ser explorado para aumentar a produção do CLA.

Dhiman et al. (1998) observou aumento na produção de CLA comparando com dietas com dois terços ou um terço forragem. Demostraram que animais em $100 \%$ de pastejo podem atingir valores médios de $21,1 \mathrm{mg} / \mathrm{g}$. Esse valore é bem mais elevado do que os valores encontrados para animais consumindo forragem conservada e concentrados. Jiang et al. (1996) demonstraram que, com ingestão constante de linoléico, valores de CLA podiam ser alterados com a variação da relação concentrado:volumoso. Beaulieu \& Drackley (2001) mediram o conteúdo médio e a variação de CLA em amostras de carne e leite obtidas no comércio (Illinois, EUA) durante o período de um ano. Os valores mais elevados de CLA na carne foram para pastejo exclusivo, mas mesmo o pastejo parcial aumentou o valor de CLA. Para leite, ao contrário de carne, não foi observado efeito da estação do ano. Também não houve efeito para raça e fonte de gordura suplementar.

Huang et al. (2001) obtiveram aumentos no teor de CLA de $4 \mathrm{mg} / \mathrm{g}$ gordura para $7 \mathrm{mg} / \mathrm{g}$ gordura com o oferecimento de $1 \%$ de CLA na dieta e para $13 \mathrm{mg} / \mathrm{g}$ gordura com $1 \%$ de CLA mais 4\% de óleo de soja. Com o CLA protegido como sais de cálcio, maiores teores de CLA no leite foram obtidos, sendo respectivamente $9 \mathrm{mg} / \mathrm{g}$ gordura e $14 \mathrm{mg} / \mathrm{g}$ gordura em situações análogas ao do CLA livre, descritos acima. O maior enriquecimento em CLA com a proteção em sais de cálcio foi também observado por Hawley et al. (2001)

Palmquist \& Griinari (2001) conseguiram uma combinação de óleo de girassol e óleo de peixe que maximizou a conversão do ácido linoléico em CLA, medido como 
c9,t11. Os valores mais elevados ocorreram quando os 3\% de óleo na MS da dieta tinham composição entre 33-67\% de óleo de peixe ou de óleo de girassol. Eles foram cerca de 50 a $70 \%$ superiores a $100 \%$ de óleo de girassol ou $100 \%$ óleo de peixe, respectivamente. $\mathrm{O}$ valor numérico mais elevado foi $61 \mathrm{mg} / \mathrm{g}$ gordura, valor mais de 10 vezes a média usual encontrada no leite americano. Em um experimento semelhante, Whitlock et al. (2002), comparando dietas com $2 \%$ de gordura suplementar com metade desta vindo de óleo de peixe ou grão de soja extrusado, apenas de cada uma destas fontes, observaram valores de CLA, em mg/g de gordura, de 1,82, 2,03 e 1,16, respectivamente, para o tratamento com as duas fontes, só com o óleo de peixe ou só com a soja extrusada. Esses autores defendem que o fato do teor da dieta com ambas as fontes ter sido maior que a média entre as outras duas, evidenciaria o efeito do óleo de peixe em aumentar a conversão dos precursores do CLA provenientes de outros alimentos.

Kelly et al. (1998), com dietas com óleos ricos em linoléico (girassol), aumentaram a concentração de CLA para $19,1 \mathrm{mg} / \mathrm{g}$ da gordura do leite comparado a valores de 13,3 e 16,7 mg/g de dietas ricas em oléico e linolênico, respectivamente . Um dado aind a mais relevante foi a variação de 9 a $51,7 \mathrm{mg} / \mathrm{g}$ para vacas de mesmo estágio de lactação que consumiam a mesma dieta e com mesmo manejo. Chouinard et al. (2001) mostraram que, além da fonte de lipídeos ter grande influência, processamentos como a extrusão, tostagem e micronização, bem como a temperatura de extrusão, causam diferenças no teor de CLA do leite. Com fontes vegetais protegidas como sais de cálcio, esses autores conseguiram aumentos de três a cinco vezes e, com a inclusão de óleo de peixe (200-400 mg/dia), o aumento no teor de CLA foi cerca de 3 vezes o valor do controle. Donovan et al. (2000) demonstraram haver um aumento de 3,7 vezes na concentração de CLA em vacas que foram suplementadas com $2 \%$ de óleo de peixe.

Um aspecto muito interessante no enriquecimento do CLA é que, independentemente de ser através da nutrição, manipulação ruminal ou suplementação direta ao animal, tem o apelo de ser um processo mais natural do que, por exemplo, a incorporação de óleo ao leite, como no caso do leite enriquecido com Omega-3. 
Recentemente, trabalhos com suínos e frangos suplementados com CLA (Thiel Cooper et al., 2001; Ramsay et al., 2001; Du et al., 2002) apresentaram valores bastante altos de CLA em animais que foram suplementados.

\subsubsection{Efeitos do CLA}

Uma gama de efeitos benéficos à saúde atribuídos ao CLA podem ser explicados através de alterações sistêmicas que este provoca em lipídeos mediadores de processos inflamatórios, como prostaglandinas e leucotrienos (Cook et al., 2001). Segundo estes autores, prostaglandinas e leucotrienos estariam na rota central dos efeitos do CLA no sistema imune. A redução da PGE2 $\alpha$ deve ser causado pelo isômero t10,c12 (Cook et al., 2001). Todavia, esses autores comentam que os efeitos do CLA relacionados com prostaglandinas ocorrem apenas quando estas se encontram em níveis alterados, isto é, acima dos níveis em que exercem importantes atividades no metabolismo.

O efeito de aumento de desempenho obtido com o c9, t11 seria devido a uma redução nos efeitos catabólicos induzidos pelo sistema imune (Cook et al., 2001, Chin et al., 1992). Dunshea et al. (1998) obtiveram drásticas reduções nas espessuras de gordura sub-cutânea de suínos com a suplementação de CLA. Ostrowska et al. (1999) examinaram, em suínos em crescimento, os efeitos de dietas suplementadas com CLA na composição da carcaça e nas taxas de acréscimo de gordura, proteína, água e matéria mineral. Estes autores observaram que o CLA aumentava a deposição de tecido magro e reduzia a deposição de gordura em aproximadamente 31\%. Trabalhos com ratos demonstraram reduções significativas no peso de todos os depósitos de gordura de animais recebendo dietas com CLA (DeLany, 2000). Comparando relações 50:50 e 80:20 do c9,t11:t10,c12, Mohede et al. (2001), obtiveram melhores resultados de resposta imune, medida através da taxa de seroproteção, apenas com as proporções iguais entre os isômeros, indicando que o t10,c12 deve ser aquele ligado a este efeito. 


\subsubsection{Efeito anticancerígeno}

Os tumores na glândula mamária são particularmente sensíveis aos efeitos do CLA, o que pode ser explicado, em parte, pela acumulação preferencial do CLA em lipídeos neutros de adipócitos que é o tipo de célula predominante no tecido mamário (Ip, 2001). Segundo Ip, o CLA depositado nos adipócitos pode teoricamente servir como "efeito parácrino" na regulação de crescimento das células epiteliais e os dois principais isômeros (c9,t11 e t10,c12) estariam envolvidos. Ip et al. (2001b) descobriram que, além dos efeitos diretos do CLA no epitélio mamário, ele também age reduzindo a diferenciação das células do estroma mamário e na redução na capacidade do estroma mamário em formar redes microcapilares (angiogênese). Estes efeitos contribuiriam para a inibição da carcinogênese mamária. Já Ip (2001a) observa que o ácido vaccênico pode ter o mesmo efeito anticarcinogênico que o CLA, mas enquanto este precisaria cerca de 100 nanomoles/mg lipídeo, o equivalente em ácido vaccênico para o mesmo efeito seria $2 \%$.

O estudo, através de "differential display", mostrou que o tratamento com CLA leva à modulação de uma gama de biomarcadores que sugerem tanto um decréscimo em proliferação celular, como um aumento de apoptose (Ip, 2001). Resultados semelhantes são reportados por Whale et al. (2001), cujos estudos usando linhagens celulares de glândula mamária e próstata, nas quais foram usadas misturas de CLA e uso dos isômeros c9,t11 e t10,c12 separadamente, evidenciaram efeitos em mecanismos de sinalização celular associados com inibição de gênese de tumores e proliferação celular que incluem: indução do redox de enzimas, atenuação da ativação do fator de transcrição induzida pela citoquinina, ativação de isoformas de proteína $\mathrm{C}$ quinases específicas envolvidas em eventos proliferativos ou apoptose, modulação da produção de eicosanóides (da expressão genética à formação do produto). Há claramente uma interação nutriente-gene para os efeitos anticancerígenos deste ácido graxo.

Apesar de bem estabelecido para modelos animais e culturas de células e tecidos, ainda faltam trabalhos mostrando efeito anticancerígeno em humanos. Bognoux 
et al. (2001) compararam o teor de CLA em mulheres que tinham carcinoma invasivo localizado na mama $(n=213)$ com mulheres com tumores benignos $(n=84)$ e não encontraram relação entre o teor de CLA e agressividade e/ou a recorrência de câncer (que normalmente ocorre em 1/3 das pacientes). Em parte esse resultado pode ser devido às pequenas concentrações encontradas (média de 0,44\%, variando de 0,19 a 0,85\%). Há, todavia, evidências epidemiológicas que populações com maiores consumos de leite e produtos lácteos teriam menor incidência de câncer mamário (Knekt et al., 1996). Dados destes autores permitem inferir que a redução de risco de câncer deve ocorrer com uma ingestão de cerca de $350 \mathrm{mg}$ CLA por dia. Considerando $5 \mathrm{mg}$ CLA/g de gordura o teor médio no leite, seria necessários aproximadamente 2 litros de leite por dia. Se estes números estiverem certos, parece interessante um aumento no teor de CLA no leite. Evidentemente, mais dados precisam ser gerados para determinar mais precisamente o valor de teor de CLA no leite que deve ser objetivado e uma melhor contabilidade de CLA, considerando outras fontes também é necessário.

\subsubsection{Efeito do CLA na mudança da composição do leite}

Os processos metabólicos que regulam a composição do leite e sua produção são controlados pela quantidade e perfil dos nutrientes absorvidos e a competição pelos diferentes tecidos, mediados por um grande número de hormônios de maneira complexa e interativa. Conseqüentemente, mudanças na composição do leite são usualmente menos óbvias do que esperadas. A nutrição tem, ainda, o maior impacto na composição do leite. Dos sólidos do leite, a gordura é a mais facilmente alterada. Há condições das dietas que podem predispor à depressão da gordura do leite (DGL), como: tamanho de partícula reduzido, baixo teor de volumoso, uso de ionóforos e gordura ativa no rúmen (Sutton, 1989; Van Soest, 1994). Classicamente, explicava-se a DGL que ocorre com dietas de alto concentrado baseando-se na teoria glicogênica/insulínica. De acordo com esta teoria, um aumento na ingestão de concentrado aumentaria a concentração da insulina circulante, a qual aumentaria a partição de nutrientes para deposição no tecido adiposo, diminuindo a quantidade de precursores para síntese de gordura na glândula 
mamária que seria irresponsiva à insulina (Van Soest, 1994). Entretanto, diferentes autores não observaram a DGL quando o teor de insulina circulante foi cronicamente elevado (McGuire et al., 1995; Griinari et al., 1997a). Isto reforçou a idéia que a DGL poderia também ser causada pela inibição direta da glândula mamária em algum nível das rotas bioquímicas de síntese de gordura por alguma substância produzida pelo rúmen recebendo dietas de alto concentrado. Ação direta dos ácidos graxos trans 18:1 na DGL foram propostas primeiramente por Davis \& Brown (1970). Pennington \& Davis (1975) também associaram os trans-18:1, produzidos pela hidrogenação parcial de ácidos graxos poliinsaturados, com DGL. Astrup et al. (1976) e Selner \& Schultz (1980) forneceram suplementos contendo ácidos graxos poliinsaturados de óleos vegetais e observaram um decréscimo na gordura do leite, também atribuído a formação de trans18:1 no rúmen. Wonsil et al. (1994) confirmaram a relação entre DGL e ácidos octadecadienóicos baseado na saída de trans-18:1 do rúmen. Gaynor et al. (1994) estudaram o efeito da infusão abomasal de uma mistura de ácidos graxos cis ou trans sobre a produção e composição do leite de vacas da raça Holandês de alto potencial (50 $\mathrm{kg} / \mathrm{d}$ ) com aproximadamente 55 dias de lactação. Os resultados demonstraram que os ácidos graxos trans reduziram o percentual de gordura mais intensamente que os ácidos graxos de configuração cis, em relação ao grupo controle (25\% e 5\%, respectivamente). Gaynor et al. (1995), estudando o efeito do fornecimento de dietas com $40 \%$ (controle) ou $80 \%$ de concentrados sobre parâmetros metabólicos e produtivos de vacas com cerca de 110 dias de lactação, encontraram uma redução da percentagem de gordura no leite dos animais recebendo dieta com alto teor de concentrados. Estes autores observaram uma correlação negativa entre a concentração de ácidos graxos trans-C18:1 no leite e a concentração de gordura no leite.

Os ácidos graxos trans têm origem na biohidrogenação parcial de ácidos graxos poliinsaturados no rúmen. Piperova et al. (1998) usaram dietas que maximizavam a concentração de ácidos graxos trans $(15,6 \%$ da gordura do leite ) para demonstrar que estes ácidos graxos diminuíram a atividade da acetil CoA carboxilase em $61 \%$ e a atividade da Sintetase de ácidos graxos em 54\% comparados ao grupo controle para os 
quais foi oferecida dieta com 1,88\% de ácidos graxos trans na gordura do leite. Essas duas enzimas seriam os pontos chaves de regulação da síntese de novo na glândula mamária.

Griinari et al. (1998) testaram a hipótese de que duas condições são necessárias para a produção de ácidos graxos "trans" e a ocorrência da depressão da gordura do leite: 1) a presença de substrato ruminal na forma de ácidos graxos insaturados e 2) um ambiente ruminal modificado, o qual leva à incompleta biohidrogenação. Para tal, fizeram um experimento fatorial $2 \times 2$ associando dietas de alta e baixa relação volumoso:concentrado (50:50 x 20:80) com suplementação de gorduras saturada e insaturada. A quantidade de fibra na dieta e o tipo de gordura tiveram efeitos significativos sobre a percentagem e produção de gordura do leite, sendo que os efeitos foram mais pronunciados quando gordura insaturada foi adicionada à dieta de baixo teor de fibra (20:80). Neste caso, a percentagem e produção de gordura foram 30 e $35 \%$ menores, respectivamente, em relação as vacas recebendo dieta de alto teor de fibra (50:50). A adição de gordura insaturada aumentou a percentagem de ácidos graxos transC18:1 na gordura do leite. Esse efeito não foi observado pela variação do nível de fibra, também não havendo interação entre tipo de gordura e quantidade de fibra da dieta. A análise do perfil de isômeros destes ácidos graxos trans-C18:1 revelou um aumento altamente significativo do isômero C18:1 trans-10 na gordura do leite dos animais recebendo dieta baixa em fibra adicionada de gordura insaturada, os quais também haviam apresentado maior depressão de gordura (-27\%). Com base nestes resultados, os autores concluíram que a depressão da gordura do leite está associada com o aumento da concentração do isômero trans-10 (C18:1) na gordura do leite, favorecida pela presença de ácidos graxos insaturados e alto teor de concentrados na dieta dos animais. Chouinard et al. (1998) examinaram o efeito direto do CLA na composição do leite através da infusão abomasal de uma mistura comercial do isômero de CLAs para vacas leiteiras. Essa mistura continha aproximadamente 60\% de CLA com a predominância dos isômeros 9,11 e 10,12. Depois de 5 dias de infusão (0, 50, 100 e 150 g/d), houve uma dramática redução no teor de gordura do leite (Figura 2). 


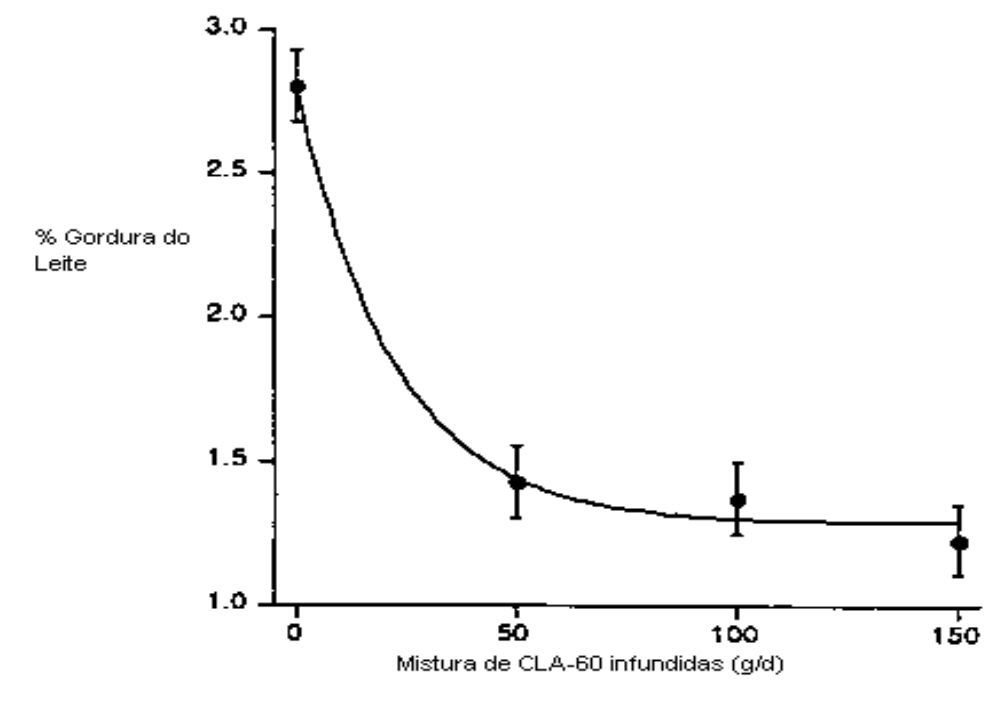

Figura 2 - Efeito da infusão abomasal of CLA-60 no teor de gordura do leite

Posteriormente, Griinari et al. (1999) encontraram uma correlação negativa entre concentração ruminal do isômero trans10, cis12 e percentagem de gordura do leite.

A biohidrogenação de ácidos graxos poliinsaturados no rúmen para 18:2 trans10, cis-12 parece ser favorecida em alguns tipos específicos de dietas. Além da presença de gordura poliinsaturada, baixos valores de $\mathrm{pH}$ ruminal parecem ser determinantes para a formação de isômeros de CLA com ligações duplas do tipo trans na posição 10 da cadeia de ácido graxo. Dietas com alto teor de concentrados, baixo teor de forragens, presença de forragens finamente picadas e adição de ionóforos têm resultado em valores mais elevados de 18:2 trans10, cis12 (Baumgard et al., 2000). Estas são as mesmas condições dietéticas nas quais são observadas depressão da gordura do leite (Van Soest, 1994).

Baumgard et al., (2000) demonstraram que é um isômero específico que inibe a síntese de gordura na glândula mamária e que a infusão de menos de $10 \mathrm{~g}$ do ácido linoléico com duas duplas ligações conjugadas nas posições 10 (configuração trans) e 12 
(configuração cis) foi capaz de reduzir em 50\% a síntese de gordura na glândula mamária de vacas em lactação. Já havia sido demonstrado que o t10,c12 é o responsável por crescimento mais magro em camundongos (Park et al., 1999).

Na glândula mamária, o isômero t10, c12 inibe a síntese de novo de ácidos graxos e assim diminui a proporção de ácidos graxos de cadeia curta. Isso é uma vantagem, pois a gordura com mais baixo teor de ácidos graxos de cadeia curta é relacionada com menores riscos de doenças cardiovasculares. A redução, em base molar, de cerca de $80 \%$ da lipogênese, pode ser atribuída à redução dos ácidos graxos provenientes da síntese de novo (Chouinard et al., 1999, Baumgard et al., 2000).

Há uma correlação positiva entre o teor ácidos graxos trans C18:1 e CLA (Jiang et al., 1996, Akerlind, 1999). De uma forma geral, parece que isômeros de CLA ou seus metabólitos que contenham uma dupla ligação de configuração do tipo trans na posição 10 da cadeia de ácido graxo parececem ter um efeito inibitório sobre a síntese de gordura do leite (NRC, 2001).

\subsubsection{Possíveis mecanismos de ação do CLA}

O mecanismo exato pelo qual o CLA atua no metabolismo de lipídeos não está totalmente elucidado. No caso da síntese de gordura do leite, evidências indicam que a inibição se dá pela da redução da síntese de novo (Loor \& Herbein, 1998; Chouinard et al., 1999; Giesy et al., 1999a), através da inibição da atividade da ACC e da FAS na glândula mamária (Loor et al., 1998; Piperova et al., 1998; Piperova et al., 2000). Piperova et al. (2000) observaram uma redução de 44\% na atividade enzimática da FAS e de $61 \%$ na atividade da ACC na glândula mamária de vacas lactantes que receberam dietas suplementadas com 5\% de óleo de soja. A análise do perfil de isômeros no leite demonstraram maior concentração de trans10, cis12 na dieta onde houve redução da atividade enzimática, o que é compatível com a redução na síntese de gordura no leite,

uma vez que há aumento na relação AGCL/ACCC. A síntese de novo resulta na formação de ácidos graxos de cadeias curta e média (<16C), dentre os quais estão os 
ácidos mirístico $\left(\mathrm{C}_{14}\right)$ e palmítico $\left(\mathrm{C}_{16}\right)$, relacionados com uma maior incidência de aterosclerose (Williams, 2000). Portanto, a redução da quantidade de gordura do leite pela ação do CLA trans10, cis12 é acompanhada de uma mudança favorável no perfil desta gordura, conferindo ao produto maior qualidade nutricional.

Trabalhos recentes têm procurado estudar o efeito do CLA na concentração de RNAm das enzimas limitantes. Entretanto, é difícil estabelecer uma relação causal e identificar o mecanismo envolvido unicamente a partir da abundância da enzima limitante. A inibição da síntese de gordura, por muitos e diferentes mecanismos, pode eventualmente se traduzir em redução da expressão das enzimas reguladoras.

Além da redução da síntese de novo na glândula mamária, outros mecanismos podem também estar atuando para que haja depressão da gordura do leite por ação do CLA. Esses mecanismos podem incluir efeitos físicos da alteração do perfil de ácidos graxos produzidos. Chilliard et al. (2000) citam, por exemplo, que o fato dos ácidos graxos trans terem ponto de fusão mais elevado que seus isômeros correspondentes cis, e uma menor fluidez nas estruturas celulares, poderiam limitar o seu empacotamento e/ou secreção. Esses mesmos autores comentam que é provável que diferentes perfis de ácidos graxos, bem como a posição destes na molécula de glicerol, contribuam juntos, através da fluidez da gordura do leite, para um sistema geral de regulação, assim integrando os efeitos complexos de numerosos fatores fisiológicos e ambientais que podem modificar a composição da gordura do leite.

Outros mecanismos que podem estar envolvidos na regulação do metabolismo de lipídios pelo CLA seriam: aumento na lipólise, aumento na oxidação de ácidos graxos e diminuição na absorção de ácidos graxos. No caso do aumento da lipólise, há relatos de aumento da atividade da HSL e da lipólise induzida por catecolaminas em adipócitos de ratos que foram tratados com CLA (Pariza et al., 1997). Park et al., (1997), observam que uma mistura de CLAs (sem especificar os isômeros) reduziu a atividade da lipoproteína lipase e aumentou a liberação do glicerol no meio de cultura de células 3T3L1. Esses mesmos efeitos foram comprovados por este mesmo grupo (Park et al., 1999) apenas para o isômero trans10, cis12, sendo que o cis9, trans11 não teve efeito. Estes 
autores ainda observaram efeito da suplementação CLA na atividade de carnitinapalmitoiltransferase (CPT) em ratos, enzima esta limitante para a beta-oxidação. O efeito foi significativo para tecido adiposo epididimal de ratos alimentados, e no músculo esquelético para os ratos em jejum. Não houve efeito para a CPT hepática. Portanto, o CLA aumentaria a beta-oxidação no músculo esquelético e tecido adiposo, mas não no fígado. Em geral, estes efeitos são consistentes com o menor teor de gordura na carcaça de ratos e suínos encontrados por alguns autores. Park et al. (1997) observaram uma redução na deposição de gordura na carcaça e sugeriram um efeito anti-obesidade do CLA. West et al. (2000) não observaram redução na lipogênese de novo no tecido adiposo de ratos recebendo dietas com CLA trans10, cis12. Entretanto, estes resultados sugerem que alterações possam estar ocorrendo no fígado ou no processo de captura e reesterificação de ácidos graxos provenientes da circulação.

Banni (2001) listou algumas maneiras pelas quais o CLA interfere com o metabolismo de lipídeos: 1) incorporação em tecidos ricos em lipídeos neutros; 2) metabolizado, como ácido linoléico e, dessa forma, competindo e influenciando a dessaturação e elongação do ácido linoléico. 3) $\beta$-oxidado nos peroxissomos. Essas atividades são maiores em tecidos que o CLA acumula (tecido mamário e adiposo), o que explica sua ação sem afetar o organismo como um todo. A beta-oxidação no perixossomo pode ativar os receptores ativados do proliferador de peróxissomo (PPAR) o que poderia explicar o aumento de retinol livre causado pelo CLA e a influência na expressão gênica. 


\section{MATERIAL E MÉTODOS}

\subsection{Fase I - Determinação do teor de CLA em vários alimentos}

\subsubsection{Amostras de carne bovina}

O corte selecionado para todas as amostras foi o Longissumus dorsi. As amostras foram coletadas e estocadas. Foram coletadas amostras de carne bovina de 3 sistemas de produção: 1) pastejo suplementado com ração; 2) confinamento convencional e 3) confinamento com alto concentrado.

As amostras de carne bovina proveniente de animais terminados em pastagem foram coletadas da estação experimental do Instituto de Zootecnia localizada em BrotasSP. Os animais pertenciam a um experimento com os animais sendo suplementados com $1,5 \mathrm{~kg}$ de suplemento à base de milho e farelo de soja. Esses animais foram abatidos com 3 anos e a suplementação durou 58 dias levando os animais de um peso médio inicial de 485 $\pm 33 \mathrm{~kg}$ até o abate com $524 \pm 44 \mathrm{~kg}$ (Glândula mamária =0,655 kg/cab). Anteriormente a esta fase de suplementação, esses animais receberam apenas pastagem e sal mineral.

A amostragem feita para animais confinados com dietas convencionais foi realizada no Centro de Pesquisa da Pecuária do Sudeste, da EMBRAPA, na cidade de São Carlos-SP. Foram amostrados 5 animais Nelore X Canchim e um Nelore. Antes do confinamento os animais amostrados permaneceram, após a desmama, 4 meses em pastejo rotacionado de Coast-cross (Cynodon dactylon), sendo que metade deles receberam ração suplementar (3 kg/dia) e, a outra metade, apenas pasto e sal mineral. O confinamento propriamente durou 147 dias. A dieta consistia, na MS, de 60\% silagem de milho e 40\% concentrado a base de milho, farelo de soja e farelo de trigo. Na dieta havia monensina 
sódica (30 mg/kg MS). O ganho médio diário dos 15 animais do experimento foi 1,44 $\pm 0,05 \mathrm{~kg} / \mathrm{dia}$, não havendo efeito para o tratamento prévio, isto é, com ração e sem ração a pasto (Cruz et al., 2000). O elevado ganho no confinamento, em parte, deveu-se a crescimento compensatório. O ponto de abate foi determinado através da espessura de gordura mínima de $4 \mathrm{~mm}$. Para os 6 animais amostrados, a espessura média de gordura foi de $8 \pm 2 \mathrm{~mm}$ e o peso $468 \pm 61 \mathrm{~kg}$.

As amostras de carne bovina provenientes de animais em confinamento com alto concentrado foram coletadas de animais terminados nas instalações de confinamento experimental da Faculdade de Zootecnia e Engenharia de Alimentos da Universidade de São Paulo, em Pirassununga-SP (Bulle, 2000; Ribeiro, 2000). Os seis animais amostrados eram bovinos resultantes de cruzamento de touros de raça Continental $(n=2)$ ou Britânica (n =4) com vacas Caracu X Nelore e receberam uma dieta entre $79 \%$ a $85 \%$ de concentrado (milho, polpa cítrica, farelo de soja e grão de soja extrusado) e, como volumoso, bagaço in natura de cana de açúcar. Na dieta destas animais havia ainda $30 \mathrm{mg} / \mathrm{kg}$ de MS de monesina sódica. Esses 6 animais foram abatidos com 12 meses, pesando $394 \pm 41 \mathrm{~kg}$, após 112 dias confinamento, com ganho médio diário de 1,35 \pm 0,33 kg/cabeça. Previamente ao confinamento, esses animais foram desmamados após receberem "creepfeeding" e receberam uma dieta de adaptação com $25 \%$ de concentrado e $75 \%$ milho por 42 dias.

\subsubsection{Amostras de Leite}

As amostras de leite foram coletadas em 6 diferentes propriedades, metade das quais de rebanho da raça Holandesas (Bos taurus) e, a outra metade, vacas da raça Gir (Bos indicus). Ambos os sistemas de produção eram baseados em pastagem e suplementados com concentrados em função da produção das vacas.Foram realizados dois períodos de coleta. O primeiro, compreendido entre Dezembro e Março de 1999, época de altas temperaturas e alta umidade (Águas). O segundo em Julho de 1999, caracterizado por temperaturas mais baixas e baixa umidade (Seca). Foram realizadas coletas das ordenhas 
compreendidas em um período de $24 \mathrm{~h}$. Após a coleta, as amostras foram imediatamente resfriadas até serem trazidas para o LNCA.

\subsubsection{Amostras Suínos e Aves}

As amostras de carne suína e de frango foram adquiridas em locais de varejo. O corte cárneo escolhido no caso dos suínos, foi a bisteca (corte entre a 5a-6a e a 13a vértebra torácica). No caso dos frangos, as carcaças, sem penas e vísceras, foram totalmente desintegradas e homogeneizadas, sendo, em seguida, separada cerca de $200 \mathrm{~g}$ de amostra para as análises.

\subsubsection{Amostras de dieta humana completa}

A refeição completa humana foi coletada no restaurante universitário da ESALQ. Amostras foram retiradas de 6 refeições completas que foram selecionadas nas quantidades desejadas por um usuário comum do restaurante (Homem, 33 anos, $75 \mathrm{~kg}$ de Peso) como se fosse para seu próprio consumo. A carne foi pesada separadamente e, depois, com os demais alimentos. Os alimentos foram desintegrados em um processador e estocados. De cada amostra, além da extração de gordura, foi feito a determinação da gordura total por extração com éter conforme AOAC (1995).

\subsubsection{Determinação dos perfis de ácidos graxos das amostras}

Para a extração de gordura, as amostras de leite, eram centrifugadas (17.800 G) por 30 minutos à $8^{\circ} \mathrm{C}$. Da nata sobrenadante, retiravam-se $400 \mathrm{mg}$ que eram usadas para a extração de gordura (Hara \& Radim, 1978). No caso das demais amostras, elas foram liofilizadas e cerca de 1,5 g era pesado para a extração pelo mesmo método. A metilação foi feita através do uso de uma solução metanólica de metóxido de sódio de acordo com Christie, (1982). O perfil de ácidos graxos foi determinado através de cromatografia gasosa 
utilizando uma coluna capilar de sílica fundida, SP-2560 (100m X 0.25 mm X 0.2mm; Supelco) e detector de ionização de chama (FID) . Utilizou-se um programa de gradiente de temperatura. O total de tempo da corrida era de 70 minutos. Usou-se como temperatura do injetor 250o C, e o detetor a 300o C. A injeção foi no modo "split", com relação 21:1. O gás de arraste foi o Hidrogênio com fluxo de $40 \mathrm{ml} /$ minuto e 18 psi de pressão na cabeça da coluna.

O perfil de ácidos graxos é expresso em porcentagem do total de ácidos graxos. Como padrão, foi usado o CRM-164 (Commission of the European Communities, Comunity Bureau of Reference, Brussels, Belgium), que tem valores certificados para 11 ácidos graxos, usados para estabelecer os fatores de correção para cada um dos ácidos graxos certificados que foram usados para transformar o pico em porcentagem em área para peso (mg/g ácidos graxos totais).

\subsubsection{Análise Estatística}

Foi feita análise de variância (SAS, 2000), como amostras inteiramente casualizadas, para todos os dados separados por categoria (leite, carne bovina, carne de monogástricos) e por origem e também todas as amostras juntas. Foram feitas regressões para relacionar o teor de gordura do leite com o CLA e seus isômeros e do ácido vaccênico e so valores de ácido rumênico e o vaccênico.

\subsection{Fase II - Suplementação de vacas lactantes em pastejo com sais de cálcio de CLA}

\subsubsection{Animais, manejo e tratamentos}

Foram utilizadas 30 vacas mestiças Holandês X Zebu em pastejo rotacionado de Estrela-Africana (Cynodon nlenfuensis var. Nlemfuensis) na Estação Experimental Santa Mônica, na cidade de Valença-RJ, pertencente a EMBRAPA Gado 
de Leite. Os animais foram mantidos em 14 piquetes de 0,5 ha, com dois dias de ocupação e 28 dias de período de pastejo.

Os tratamentos foram designados ao acaso para cada um dos animais que compunham os 15 blocos (2 vacas por bloco). Os critérios para formação dos blocos foram: produção prévia de leite, paridade, condição corporal e peso.

Todos animais receberam 4,0 kg de um concentrado cuja composição pode ser vista na Tabela 6, abaixo:

Tabela 6. Composição do concentrados oferecido às vacas em pastejo e composição química determinada.

\begin{tabular}{|c|c|c|}
\hline Ingredientes & $\mathrm{kg} / \mathrm{dia}, \mathrm{MO}$ & $\%, \mathrm{MS}$ \\
\hline Milho, grão moído & 2,35 & 58,5 \\
\hline Farinha de Peixe & 1,00 & 24,9 \\
\hline Farelo de Trigo & 0,23 & 5,5 \\
\hline Farelo de Soja & 0,22 & 5,5 \\
\hline Núcleo Vitamínico-Mineral ${ }^{1}$ & 0,20 & 5,5 \\
\hline Total & 4,00 & 100,0 \\
\hline Composição Química & & $\% \mathrm{MS}$ \\
\hline Matéria Seca & & 89,92 \\
\hline Proteína Bruta & & 23,61 \\
\hline Extrato Etéreo & & 5,62 \\
\hline Matéria Mineral & & 11,82 \\
\hline \multicolumn{3}{|c|}{$\begin{array}{l}\text { Composição: Cálcio: } 37,5 \mathrm{~g} / \mathrm{kg} \text {; Fósforo: 19,5 g/kg; Magnésio: } 4,5 \mathrm{~g} / \mathrm{kg} \text {; Enxofre: } 1,5 \mathrm{~g} / \mathrm{kg} \text {; } \\
\text { Sódio: } 27 \mathrm{~g} / \mathrm{kg} \text { Cobre: } 240 \mathrm{mg} / \mathrm{kg} \text {; Ferro: } 300 \mathrm{mg} / \mathrm{kg} \text {; Manganés: } 300 \mathrm{mg} / \mathrm{kg} \text {; Cobre: } 240 \mathrm{mg} / \mathrm{kg} \text {; } \\
\text { Zinco: } 450 \mathrm{mg} / \mathrm{kg} \text {; Cobalto: } 9 \mathrm{mg} / \mathrm{kg} \text {; Cobre: } 240 \mathrm{mg} / \mathrm{kg} \text {; Selênio: } 8 \mathrm{mg} / \mathrm{kg} \text {; Vitamina A: } 20000\end{array}$} \\
\hline
\end{tabular}

O concentrado do período experimental foi formulado para complementar a forragem ingerida a pasto e que a dieta completa fornecesse $115 \%$ das exigências de proteína metabolizável, bem como pelo menos $20 \%$ a mais das exigências de vitaminas, 
macro e micro-minerias, determinadas pelo sistema de formulação de Cornell (CNCPS 3.1). Dois quilos de matéria original de concentrado foram oferecidos 2 vezes ao dia, após a ordenha da manhã e da ordenha da tarde

Os animais foram separados em 2 grupos e receberam, do dia 28 ao dia $84 \mathrm{em}$ lactação (DEL), os seguintes tratamentos: 1)150 g de sais de cálcio de ácidos graxos (Megalac; Controle) ou 2) 150 g de sais de cálcio de CLA-60.

Os ácidos graxos dos 2 suplementos eram saponificados, como forma de protegê-los ao menos parcialmente de fermentação ruminal, minizando a biohidrogenação e, portanto, a diminuição do teor de CLA que chega aos intestinos.

O CLA-60 contém 60\% de isômeros de CLA na seguinte proporção: 24\% do c/t $9, \mathrm{t} 11,35 \%$ do c/t 10,c12, $15 \%$ do c/t 8,10, 17\% t11,t13 e 9\% outros. Portanto, considerando que os sais de CLA-60 produzidos para este experimento (Church \& Dwight, Princeton, NJ) continham 20\% de cinzas e $80 \%$ de ácidos graxos. Portanto, houve um consumo equivalente a $72 \mathrm{~g}$ de CLA ou $25 \mathrm{~g}$ do c/t 10,12.

Foi estudado também o efeito residual pós-tratamento. Assim, em seguida ao período de tratamento descrito acima, a suplementação com os sais de cálcio (Megalac e CLA-60) foi suspensa e os concentrados substituídos por concentrados convencionais do $85^{\circ}$ ao $112^{\circ}$ DEL.

Convencionou-se chamar o período da $4^{\mathrm{a}}$ a $11^{\mathrm{a}}$ semana (28-84 DEL), de Período de Tratamento e da $12^{\mathrm{a}}$ a 15 a semana (85-112 DEL) de Período Residual.

$\mathrm{Na}$ Tabela 7, abaixo são apresentados os resultados das análises bromatológicas. O concentrado utilizado durante o período residual foi uma ração comercial à base de farelo de trigo.

O extrato etéreo do concentrado do período de tratamento reportado na Tabela 7 não inclui a contribuição das gorduras protegidas que eram misturadas em cada refeição no momento do consumo. O valor de extrato etéreo considerando os sais de cálcio do concentrado é $5,4 \%$ da MS. 
Tabela 7. Resultados das análises bromatológicas dos concentrados oferecidos.

\begin{tabular}{ccc}
\hline & \multicolumn{2}{c}{ Concentrado } \\
\hline Análises & Período Tratamento & Período Residual \\
\hline Matéria Seca, \% & 89,6 & 88,16 \\
Proteína Bruta, \% MS & 24,1 & 17,91 \\
Extrato Etéreo, \% MS & 2,9 & 2,55 \\
Matéria Mineral, \% MS & 14,4 & 14,11 \\
\hline
\end{tabular}

1 - MS - Matéria Seca

\subsubsection{Avaliação da Produção e Composição do Leite}

A determinação da produção de leite foi feita diariamente e individualmente, nas duas ordenhas, realizadas às $6 \mathrm{~h} 00 \mathrm{e}$ às $14 \mathrm{~h} 00$. Em 3 dias da semana (Segunda-feira, Quinta-feira e Sábado) eram coletadas amostras de leite para determinação da composição do leite tomando-se o cuidado de agitar o leite total nos balões coletores na razão de 1 segundo para cada litro de leite produzido, com no mínimo 10 segundos para volumes abaixo de 10 litros. Foram analisados os teores de gordura, proteína, lactose e sólidos totais através de equipamento automático (Laboratório de análises de leite, EMBRAPA Gado de Leite, Juiz de Fora, MG) através de um analisador computadorizado (Bentley 2000) baseado na absorção de ondas na faixa do infravermelho.

\subsubsection{Avaliação do teor do nitrogênio uréico do leite}

Para avaliação do teor do nitrogênio na forma de uréia do leite (MUN), foram coletadas amostras de leite uma vez por semana de todas as vacas do experimento. As análises foram feitas no semanalmente utilizando um método enzimático (Uréia EnzColor, Laborclin, Curitiba-PR) e as leituras feitas em espectrofotômetro à $630 \mathrm{~nm}$. Foi 
feito um "pool” de amostras pré-experimentais que serviram como amostra controle para comparações inter-rodadas.

\subsubsection{Parâmetros plasmáticos}

O sangue foi coletado semanalmente por punção da veia coccígea, e o plasma obtido por centrifugação estocado a $-20^{\circ} \mathrm{C}$ até o momento da análise. Foram analisados: ácidos graxos livres (AGNE), triglicerídeos (TGA), colesterol total e glucose. Para as analises de AGNE foi usado um metódo enzimático-colorimétricos (NEFA C, Wako Chemicals) com as leituras feitas em espectrofotômetro. Foram analisadas todas as amostras para AGNE (n=360). Os dados de TGA e glucose foram analisados para as semanas 4, 6, 8 e 10 do perído de tratamento e todas as 4 semanas do período residual As análises de colesterol foram feitas para as mesmas amostras utilizadas para TGA e glucose, no período de tratamento, e apenas para as amostras das semanas 13 e 15, através de um metódo enzimático-colorimétricos (Colesterol Enz-Color, Biodiagnóstica) com leituras feitas em espectrofotômetro.

A determinação de glucose foi realizada por leitura direta (enzima glicose oxidase imobilizada em membrana) em autoanalisador YSI 2700 Select (Biochemistry Analyser, Yellow Spring, OH, EUA).

\subsubsection{Análise Estatística}

Para os dados de produção, composição do leite, peso vivo, condicão corporal e parâmetros metabólicos (MUN, AGNE, TGA, colesterol e glucose) foram feitas análises de variância utilizando-se PROC GLM do SAS (2000) para o período de tratamento e para o período residual. Quando houve interação tempo (semana) versus tratamento, procedeu-se uma análise de variância em cada tempo. Os dados de perfil de ácidos graxos foram analisados como parcelas sub-divididas, também com o SAS (2000). 
A persistência da produção de leite foi comparada através das inclinações das curvas pelo teste de intervalo de confiança da diferença das inclinações, conforme Neter e Waserman (1974).

Os efeitos foram considerado altamente significativos quando $\mathrm{P}<0,01$, significativo quando com $\mathrm{P}<0,05$ e que houve uma tendência quando $\mathrm{P}<0,10$. 


\section{RESULTADOS E DISCUSSÃO}

\subsection{Perfis de ácidos graxos das amostras de leite coletadas em 6 diferentes fazendas, com diferentes rebanhos (Bos taurus vs. Bos indicus) e em duas épocas do ano}

A caracterização de cada uma das fazendas amostradas, para as duas épocas em que foram realizadas as coletas, pode ser observada no Apêndice 1 onde há dados médios de paridade, dias em lactação, produção de leite e teores de gordura e proteína dos animais amostrados. Um resumo da alimentação fornecida nestes mesmos locais, em cada época de coleta, é apresentado no Apêndice 2. As duas raças têm níves de produção bastante contrastantes. De forma esperada, os valores para gordura para os animais Gir (4,1-4,6\%) é bem maior que para os Holandêses (3,4-3,7\%), o que não se repete para o teor de proteína, cujos valores são semelhantes.

Os perfis de ácidos graxos determinados nas amostras de leite são apresentados na Tabela 8. Os valores representam o perfil de animais em pastagem recebendo concentrados encontrado na literatura (Christie, 1981, Chilliard et al., 2001; Lawless et al., 1998). Entretanto os valores encontrados neste trabalho se referem a animais consumindo pastagem tropical (C4) enquanto a literatura contém basicamente dados para animais recebendo forragem temperada. De forma geral as composições do leite foram bastante semelhantes (Tabela 8), especialmente entre as raças dentro na Seca.

As maiores diferenças para os ácidos graxos ficaram por conta dos valores encontrados para as vacas holandesas nas águas em relação aos demais. Na comparação Águas $\mathrm{x}$ Seca, dentro da raça holandesa, as principais diferenças ocorreram no aumento de C18:3 (+150\%), C18:2 total (+44\%), C18:1 total (+25\%) nas Águas. Compensando esse aumentos, os diversos ácidos graxos de cadeia curta (C4:0 a $\mathrm{C} 15: 0)$ foram reduzidos em cerca de 10 a $20 \%$, sendo estas reduções um pouco menores que as 
observadas para o C16:0 (-17\%). Os aumentos dos poliinsaturados está de acordo com o comportamento do perfil de ácidos graxos das gramíneas tropicais (O’Kelly \& Reich; 1976) nas quais há nas Águas um forte aumento de C18:3, e os valores mais baixos na Seca seriam função do maior uso de forragem conservada. As forragens conservadas costumam ter gorduras mais saturadas, pois processamentos de secagem ou fermentação metabolizam preferencialmente os poliinsaturados. Isso talvez ajude a explicar a maior porcentagem de gordura saturada para Holandês na Seca (Tabela 9), já que em sistemas de produção com animais desta raça há um maior uso de forragem conservada.

Tabela 8. Médias dos perfis de ácidos graxos das fazendas amostradas separadas por raça e época. $(\mathrm{g} / 100 \mathrm{~g})$

\begin{tabular}{lcccc}
\hline & \multicolumn{2}{c}{ Holandês } & \multicolumn{2}{c}{ Gir } \\
& Águas & Seca & Águas & Seca \\
\hline Amostras, & 18 & 18 & 18 & 18 \\
C 4:0 & $3.7 \pm 0.4$ & $4.1 \pm 0.7$ & $3.6 \pm 0.4$ & $3.7 \pm 0.6$ \\
C 6:0 & $2.2 \pm 0.3$ & $2.5 \pm 0.3$ & $2.3 \pm 0.4$ & $2.3 \pm 0.4$ \\
C 8:0 & $1.0 \pm 0.2^{\mathrm{b}}$ & $1.2 \pm 0.2^{\mathrm{a}}$ & $1.2 \pm 0.2^{\mathrm{a}}$ & $1.2 \pm 0.2^{\mathrm{a}}$ \\
C10:0 & $2.1 \pm 0.4$ & $2.6 \pm 0.6$ & $2.7 \pm 1.0$ & $2.5 \pm 0.6$ \\
C12:0 & $2.4 \pm 0.5$ & $3.0 \pm 0.8$ & $3.0 \pm 0.6$ & $3.0 \pm 0.6$ \\
C14:0 & $9.2 \pm 1.1^{\mathrm{b}}$ & $10.4 \pm 1.8^{\mathrm{a}}$ & $10.1 \pm 1.3^{\mathrm{a}}$ & $10.5 \pm 1.0^{\mathrm{a}}$ \\
C14:1 & $0.8 \pm 0.3^{\mathrm{b}}$ & $0.8 \pm 0.3^{\mathrm{a}}$ & $1.5 \pm 0.5^{\mathrm{a}}$ & $1.6 \pm 0.5^{\mathrm{a}}$ \\
C15:0 & $1.1 \pm 0.2$ & $1.2 \pm 0.3$ & $1.2 \pm 0.1$ & $1.3 \pm 0.3$ \\
C16:0 & $26.8 \pm 2.2^{\mathrm{b}}$ & $32.1 \pm 3.9^{\mathrm{a}}$ & $30.6 \pm 3.6^{\mathrm{a}}$ & $32.7 \pm 2.9^{\mathrm{a}}$ \\
C16:1 & $1.7 \pm 0.3^{\mathrm{b}}$ & $1.5 \pm 0.3^{\mathrm{b}}$ & $2.2 \pm 0.5^{\mathrm{a}}$ & $2.6 \pm 0.8^{\mathrm{a}}$ \\
C18:0 & $12.1 \pm 1.9^{\mathrm{a}}$ & $12.0 \pm 3.5^{\mathrm{a}}$ & $9.5 \pm 2.6^{\mathrm{b}}$ & $8.6 \pm 1.9^{\mathrm{b}}$ \\
C18:1 Total & $27.2 \pm 2.7^{\mathrm{a}}$ & $21.8 \pm 3.8^{\mathrm{a}}$ & $23.7 \pm 4.3^{\mathrm{b}}$ & $22.9 \pm 3.7^{\mathrm{b}}$ \\
C18:2 cis9,cis12 & $1.9 \pm 0.5^{\mathrm{a}}$ & $1.8 \pm 0.5^{\mathrm{a}}$ & $1.4 \pm 0.4^{\mathrm{b}}$ & $1.1 \pm 0.3^{\mathrm{b}}$ \\
C18:3 & $0.5 \pm 0.1^{\mathrm{a}}$ & $0.2 \pm 0.1^{\mathrm{b}}$ & $0.3 \pm 0.1^{\mathrm{b}}$ & $0.3 \pm 0.1^{\mathrm{b}}$ \\
C18:2 Total & $3.6 \pm 0.7^{\mathrm{a}}$ & $2.5 \pm 0.5^{\mathrm{bc}}$ & $2.6 \pm 0.6^{\mathrm{b}}$ & $2.1 \pm 0.4^{\mathrm{c}}$ \\
\hline Letras diferentes numa mesma linha indica
\end{tabular}

Letras diferentes numa mesma linha indica diferença significativa $(\mathrm{P}<0.05)$

Diferenças também foram observadas para C16:1 e C18:0. Este último com valores, nas duas épocas, próximos de 12\% para Holandês e de 9\% para Gir. No caso do C16:1 houve uma maior concentração nos animais $B$. indicus. Os maiores teores para os animais holandeses de ácido esteárico e de ácidos graxos de cadeia longa de forma geral estariam de acordo com os maiores níveis de produção e, portanto, de uma provável maior necessidade de mobilização dos tecidos de reserva. 
Na Tabela 9, podemos observar que o leite de vacas Holandesas têm menor proporção de ácidos de cadeia curta e média no verão. Um teor maior de ácidos graxos de cadeia longa indica uma maior mobilização das reservas de gordura da vaca algo que ocorre quando o consumo de energia é inferior ao necessário para manter a produção de leite. Aparentemente, no Holandês, isto pode ter ocorrido mais nas águas do que nas secas porque os animais recebem mais forragem conservada de boa qualidade e mais concentrados durante o período seco. $\mathrm{O}$ aumento de forragens conservadas pode ser o motivo do maior teor de saturados para Holandês na seca.

Tabela 9. Teores (\% dos ácidos graxos totais) de àcidos graxos de diferentes tamanhos de cadeia e saturação e relações entre ácidos graxos de diferentes saturações do leite $(\mathrm{g} / 100 \mathrm{~g})$

\begin{tabular}{|c|c|c|c|c|}
\hline & \multicolumn{2}{|c|}{ Holandês } & \multicolumn{2}{|c|}{ Gir } \\
\hline & Águas & Seca & Águas & Seca \\
\hline & \multicolumn{4}{|c|}{$\%$} \\
\hline Saturados & $59.5 \pm 3.2^{\mathrm{c}}$ & $68.0 \pm 3.5^{\mathrm{a}}$ & $63.2 \pm 4.5^{\mathrm{b}}$ & $64.4 \pm 4.1^{\mathrm{b}}$ \\
\hline Monoinsaturados & $29.7 \pm 2.6^{\mathrm{a}}$ & $24.1 \pm 3.7^{b}$ & $27.5 \pm 4.4^{\mathrm{b}}$ & $27.0 \pm 3.9^{\mathrm{ab}}$ \\
\hline \multirow[t]{2}{*}{ Poliinsaturados } & $4.1 \pm 0.9^{\mathrm{a}}$ & $2.7 \pm 0.5^{b}$ & $2.9 \pm 0.7^{b}$ & $2.3 \pm 0.4^{b}$ \\
\hline & \multicolumn{4}{|c|}{ Relações, g/g } \\
\hline C14:0/ C14:1 & $12.5 \pm 3.9^{\mathrm{a}}$ & $14.6 \pm 4.9^{\mathrm{a}}$ & $7.3 \pm 2.23^{b}$ & $7.3 \pm 2.2^{b}$ \\
\hline C16:0/ C16:1 & $16.5 \pm 2.7^{b}$ & $22.3 \pm 5.1^{\mathrm{a}}$ & $14.1 \pm 3.2^{\mathrm{b}}$ & $13.5 \pm 3.0^{\mathrm{b}}$ \\
\hline C18:0/ C18:1 & $0.4 \pm 0.1^{b}$ & $0.5 \pm 0.1^{\mathrm{a}}$ & $0.4 \pm 0.1^{b}$ & $0.4 \pm 0.1^{\mathrm{b}}$ \\
\hline Tamanho da Cadeia, $\%$ & \multicolumn{4}{|c|}{ Tamanho da Cadeia, $\%$} \\
\hline Cadeia Média $^{2}$ & $11.3 \pm 1.4^{\mathrm{b}}$ & $13.4 \pm 1.7^{\mathrm{a}}$ & $13.0 \pm 2.3^{\mathrm{ab}}$ & $12.6 \pm 2.2^{\mathrm{ab}}$ \\
\hline \multirow[t]{2}{*}{ Cadeia Longa $^{3}$} & $38.5 \pm 3.5^{\mathrm{b}}$ & $44.8 \pm 5.6^{\mathrm{a}}$ & $44.5 \pm 5.2^{\mathrm{a}}$ & $47.3 \pm 3.8^{\mathrm{a}}$ \\
\hline & $43.4 \pm 4.3^{\mathrm{a}}$ & $36.4 \pm 7.0^{\mathrm{b}}$ & $36.1 \pm 6.7^{\mathrm{b}}$ & $33.8 \pm 5.1^{\mathrm{b}}$ \\
\hline
\end{tabular}

Uma diferença entre raças ocorreu para C14:1 que foi, praticamente o dobro para 
os animais da raça Gir. O C16:1 também foi mais elevado para Gir alterando a relação 16:0/16:1. Entretanto a relação 18:0/18:1 foi semelhante entre as raças, exceto pelo valor da seca. Aparentemente a delta-9 dessaturase parece ser menos ativa para C14:0 e C16:0 em animais da raça Gir, capazes de produzir leite com maior teor de gordura, embora não apresente diferença para teor de C18:1.

Os dados para concentração dos principais isômeros de CLA, o ácido rumênico (c9.t11) e o t10,c12, para o principal precursor do ácido rumênico, o ácido vaccênico (C18:1 trans-11) e para o teor de CLA total, como a soma dos dois isômeros citados podem ser vizualisados na Tabela 10, na qual os dados são apresentados para cada uma das fazendas amostradas.

Tabela 10. Porcentagem dos ácidos graxos Vaccênico (C18:t1), Rumênico (C18:c9,t11), 18:t10,c12 e CLA total nos sistemas de produção em 2 épocas do ano ${ }^{3}$. $(\mathrm{g} / 100 \mathrm{~g})$

\begin{tabular}{|c|c|c|c|c|c|c|}
\hline & Fonte $^{1}$ & $\operatorname{Raça}^{2}$ & $\begin{array}{c}\text { Vaccênico (t11) } \\
\text { Média } \pm \text { dp }\end{array}$ & $\begin{array}{c}\text { Rumênico (c9,t11) } \\
\text { Média } \pm \text { dp }\end{array}$ & $\begin{array}{c}\text { t10,c12 } \\
\text { Média } \pm \text { dp }\end{array}$ & $\begin{array}{l}\text { CLA total } \\
\text { Média } \pm \text { dp }\end{array}$ \\
\hline Leite $1^{\mathrm{A}}$ & Águas & $\mathrm{G}$ & $30,4 \pm 6,7^{\text {abc }}$ & $12.8 \pm 4.0^{\mathrm{ab}}$ & $1.4 \pm 0.5^{\mathrm{abc}}$ & $14.2 \pm 4.0^{\mathrm{ab}}$ \\
\hline Leite $2^{\mathrm{A}}$ & & G & $18.0 \pm 7.6^{\mathrm{cd}}$ & $6.0 \pm 1.0^{\mathrm{cd}}$ & $1.3 \pm 0.5^{\mathrm{abc}}$ & $7.3 \pm 1.4^{\mathrm{def}}$ \\
\hline Leite $3^{\mathrm{A}}$ & & G & $25.2 \pm 9.2^{\mathrm{bcd}}$ & $10.5 \pm 2.0^{\mathrm{abc}}$ & $0.8 \pm 0.4^{\text {cde }}$ & $11.3 \pm 2.0^{\mathrm{abcde}}$ \\
\hline Leite $4^{\mathrm{A}}$ & & $\mathrm{H}$ & $38.0 \pm 3.5^{\mathrm{a}}$ & $10.7 \pm 5.0^{\mathrm{abc}}$ & $2.0 \pm 0.6^{\mathrm{a}}$ & $12.8 \pm 4.9^{\mathrm{abc}}$ \\
\hline Leite $5^{\mathrm{A}}$ & & $\mathrm{H}$ & $40.0 \pm 4.9^{\mathrm{a}}$ & $14.2 \pm 3.0^{\mathrm{a}}$ & $1.8 \pm 0.5^{\mathrm{ab}}$ & $15.8 \pm 2.9^{\mathrm{a}}$ \\
\hline Leite $6^{\mathrm{A}}$ & & $\mathrm{H}$ & $36.5 \pm 3.0^{\mathrm{ab}}$ & $11.3 \pm 3.0^{\mathrm{abc}}$ & $1.0 \pm 0.0^{\mathrm{bcd}}$ & $12.3 \pm 2.7^{\mathrm{abcd}}$ \\
\hline Leite 1S & Secas & G & $21.8 \pm 4.7^{\mathrm{cd}}$ & $8.7 \pm 2.0^{\mathrm{bcd}}$ & $0.3 \pm 0.5^{\mathrm{de}}$ & $8.8 \pm 2.0^{\text {bcdef }}$ \\
\hline Leite $2 \mathrm{~S}$ & & G & $17.8 \pm 4.1^{\mathrm{d}}$ & $8.6 \pm 2.0^{\mathrm{bcd}}$ & $0.0 \pm 0.0^{\mathrm{e}}$ & $8.6 \pm 2.3^{\text {cdef }}$ \\
\hline Leite $3 \mathrm{~S}$ & & G & $16.0 \pm 4.4^{\mathrm{d}}$ & $6.8 \pm 2.0^{\mathrm{cd}}$ & $0.8 \pm 0.4^{\text {cde }}$ & $7.6 \pm 1.8^{\text {cdef }}$ \\
\hline Leite $4 \mathrm{~S}$ & & $\mathrm{H}$ & $13.8 \pm 9.5^{\mathrm{d}}$ & $3.8 \pm 3.0^{\mathrm{d}}$ & $0.8 \pm 0.4^{\text {cde }}$ & $4.2 \pm 2.8^{\mathrm{f}}$ \\
\hline Leite $5 \mathrm{~S}$ & & $\mathrm{H}$ & $20.8 \pm 6.4^{\mathrm{cd}}$ & $4.3 \pm 1.0^{\mathrm{d}}$ & $1.0 \pm 0.6^{\mathrm{bcd}}$ & $5.2 \pm 0.7^{\mathrm{f}}$ \\
\hline Leite $6 \mathrm{~S}$ & & $\mathrm{H}$ & $17.7 \pm 3.1^{\mathrm{d}}$ & $6.0 \pm 1.0^{\mathrm{cd}}$ & $0.0 \pm 0.0^{\mathrm{e}}$ & $6.0 \pm 1.4^{\text {ef }}$ \\
\hline
\end{tabular}

${ }^{1}$ De $1 \mathrm{~A}$ a $6 \mathrm{~A}$, amostras coletadas nas águas, de $1 \mathrm{~S}$ a $6 \mathrm{~S}$, as mesmas fazendas mas coletadas na seca.

${ }^{2}$ Raça G é Gir (Bos indicus) e Raça H é Holandês (Bos taurus)

${ }^{3}$ Letras diferentes numa mesma coluna diferem significativamente $(\mathrm{P}<0,05)$

As concentrações de Vaccênico mais elevadas ocorreram nas Águas para ambas as raças, particularmente para o Holandês. Estes resultados demonstram que a gama de fatores capazes de alterar os teores de ácido vaccênico, que incluem o teor de ácidos graxos poliinsaturados da dieta, o teor de volumoso, a grau de maturidade da pastagem, 
o teor de concentrado da dieta, entre outros (Griinari et al., 1998b) são capazes de interagir para gerar uma variação muito significativa nas proporções relativas dos diferentes isômeros de ácidos graxos de 18 carbonos e do seu nível de biohidrogenação. A elevada queda no teor de Vaccêncio para Holandês, quando passamos das Águas para a Seca, deve estar ligada, além de um menor aporte de poliinsaturados, a uma menor biohidrogenação no rúmen de animais recebendo mais concentrado.

$\mathrm{O}$ ácido Rumênico, importante pelo seu efeito anticarcinogênico, é produzido a partir do ácido Vaccênico, pela ação da delta-9-dessaturase (Corl et al., 2000). Este processo ocorre em sua maior parte nos tecidos do animal após a absorção do Vaccênico, sendo que uma parte menor é produzida no interior do trato gastrintestinal. As regressões entre esses dois ácidos graxos foi significativa $(P<0.05)$ como pode ser observado na Figura 3.

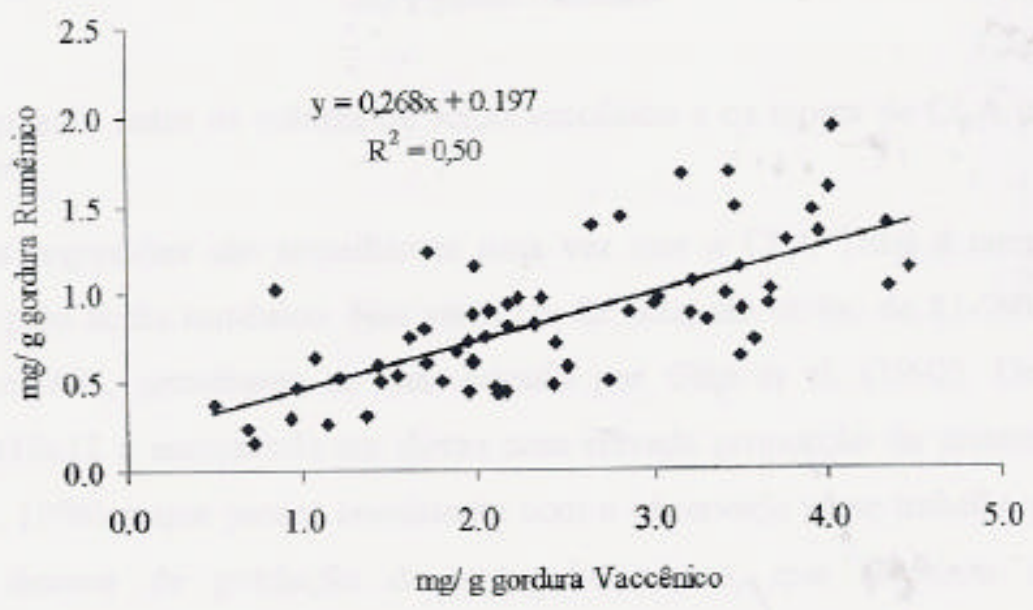

Figura 3 - Regressão entre os teores de ácido vaccênico e de ácido rumênico no leite. 
$\mathrm{Na}$ Figura 4, pode ver a regressão do Vaccêncio com o CLA total, bastante semelhante a anterior.

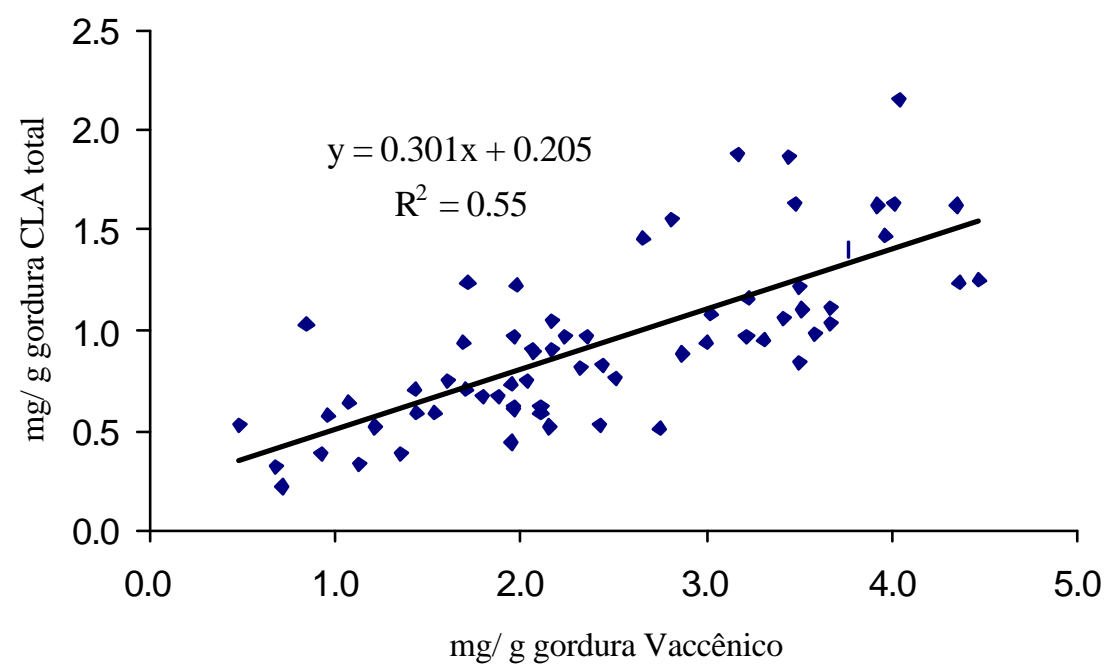

Figura 4 - Regressão entre os valores de ácido vaccênico e os teores de CLA total no leite.

As duas regressões são semelhantes uma vez que o CLA Total é constituído principalmente pelo ácido rumênico. Nas amostras de leite, ele variou de 81-99\%, com valor médio de 90\%, semelhante ao determinado por Chin et al. (1992). Uma alta proporção de t10c12 é encontrada em dietas com elevada proporção de concentrados (Griinari et al., 1998) o que parece consistente com o observado neste trabalho para as amostras do sistema de produção de vacas holandesas, que recebiam maiores quantidades de concentrados. Também consistentes são os menores valores de t10c12 encontrados para os sistemas de produção com Gir a pasto, que recebiam as menores quantidades de concentrado.

Diversos trabalhos tem demonstrado que não há mudanças significativas na concentração total de CLA ao longo da cadeia de recepção, armazenamento e processamento do leite em seus diversos derivados (Lin et al., 1992; Shanta et al., 1995, Lin et al., 1998). Portanto o conteúdo de CLA de queijos, iogurtes e sorvetes são um reflexo das características do leite que lhes deu origem. Consequentemente, a elevada variação nos teores de CLA encontradas entre sistemas de produção, raças e 
particularmente entre épocas do ano é importante (Tabela 10). Isto indica que uma melhor compreensão das causas destas variações, que ocorrem quase exclusivamente no próprio sistema de produção, permitiriam produzir derivados com teores maiores ou diferentes proporções dos diferentes isômeros de CLA. Como exemplo, a menor diferença entre as estações para os animais Gir deve estar ligada à menor suplementação com concentrados e uma maior ingestão de pastagem. Como referido anteriormente a porcentagem de forragem fresca na dieta é um dos fatores que mais influenciam o teor de CLA (Stene et al., 2001; Dhiman et al., 1999; Jahreis et al., 1997).

\subsection{Perfis de ácidos graxos das amostras de carne bovina coletdas de 3 sistemas de produção}

Os valores para os perfis de ácidos graxos das amostras de carne estão na Tabela 11, onde são apresentados os valores para os animais alimentados a pasto com suplementação, os confinados com dietas convencionais a base de volumosos, e os confinados com dietas com altas proporções de concentrado.

Houve diferença entre os animais a pasto e os animais confinados para 11 ácidos graxos analisados $(\mathrm{P}<0.05)$. Alguns ácidos graxos apresentaram teores semelhantes para as duas dietas utilizadas em confinamento e maiores para animais alimentados a pasto, entre eles o C16:0 total, o C18:0 total e o C18:3. Já para linoléico e C18:2 total, os valores mais elevados são os dos animais na dieta de alto concentrado e inferiores para os outros 2 sistemas. Um dado interessante é que o valor do Vaccêncio é semelhante entre animais confinados com alto volumoso e animais alimentados a pasto, mas é muito mais elevado para animais alimentados com grandes quantidades de concentrado. Há diferença quanto ao teor de C18:1 cis-9 (oléico) com teores mais elevados para animais confinados com dietas de alta proporção de volumosos. Isto estaria de acordo com um maior aporte dietético de oléico na dieta e uma menor biohidrogenação em dietas com, proporcionalmente, mais concentrado do que a dieta dos animais a pasto, composta quase exclusivamente de forragem. Todavia, esse raciocínio não se aplica a dieta com alto concentrado que tem teor de Vaccênico significativamente mais elevado que os outros 2 sistemas. Isso parece mostrar que há 
uma interação entre o perfil de ácidos graxos ingerido pelo animal e o ambiente ruminal para determinar maior ou menor biohidrogenação e produção de CLA. Estudos detalhados das modificações nas populações de microorganismos e nas vias de metabolização dos ácidos graxos no rúmen, em função de alterações na dieta, devem ser conduzidos.

Tabela 11. Perfil de ácidos graxos na carne bovina de diferentes sistemas de produção $(\mathrm{g} / 100 \mathrm{~g})^{1}$.

\begin{tabular}{lccc}
\hline & Pasto & & Confinado \\
& Média \pm dp & $\begin{array}{c}\text { Alto Volumoso } \\
\text { Média } \pm d p\end{array}$ & $\begin{array}{c}\text { Alto Concentrado } \\
\text { Média } \pm d p\end{array}$ \\
\hline C14:0 & $3.7 \pm 0.3$ & $3.4 \pm 0.6$ & $3.2 \pm 0.2$ \\
C14:1 & $0.3 \pm 0.2^{\mathrm{c}}$ & $1.1 \pm 0.3^{\mathrm{a}}$ & $0.6 \pm 0.1^{\mathrm{b}}$ \\
C15:0 & $0.5 \pm 0.1$ & $0.3 \pm 0.1$ & $0.4 \pm 0.1$ \\
C16:0 Total & $28.8 \pm 0.7^{\mathrm{a}}$ & $23.8 \pm 2.0^{\mathrm{b}}$ & $23.1 \pm 0.9^{\mathrm{b}}$ \\
C16:1 cis -9 & $2.3 \pm 0.3^{\mathrm{c}}$ & $4.5 \pm 0.6^{\mathrm{a}}$ & $3.6 \pm 0.4^{\mathrm{b}}$ \\
C17:0 & $1.1 \pm 0.1^{\mathrm{a}}$ & $0.8 \pm 0.0^{\mathrm{b}}$ & $0.8 \pm 0.1^{\mathrm{b}}$ \\
C17:1 & $0.4 \pm 0.0^{\mathrm{b}}$ & $0.6 \pm 0.1$ & $0.6 \pm 0.0$ \\
C18:0 & $23.1 \pm 2.4^{\mathrm{a}}$ & $14.4 \pm 2.3^{\mathrm{b}}$ & $14.7 \pm 1.3^{\mathrm{b}}$ \\
C18:1 trans-11 & $2.2 \pm 0.7^{\mathrm{b}}$ & $1.8 \pm 0.3^{\mathrm{b}}$ & $6.6 \pm 1.2^{\mathrm{a}}$ \\
C18:1 cis -9 & $30.7 \pm 3.8^{\mathrm{c}}$ & $42.7 \pm 1.8^{\mathrm{a}}$ & $36.7 \pm 2.5^{\mathrm{b}}$ \\
C18:1 Total & $34.5 \pm 3.5^{\mathrm{b}}$ & $47.4 \pm 2.3^{\mathrm{a}}$ & $45.7 \pm 1.6^{\mathrm{a}}$ \\
C18:2 cis -9,cis -12 & $2.2 \pm 0.5^{\mathrm{b}}$ & $2.1 \pm 0.8^{\mathrm{b}}$ & $3.3 \pm 0.5^{\mathrm{a}}$ \\
C18:2 Total & $2.5 \pm 0.5^{\mathrm{b}}$ & $2.6 \pm 0.8^{\mathrm{b}}$ & $4.3 \pm 0.6^{\mathrm{a}}$ \\
C18:3 & $0.5 \pm 0.0^{\mathrm{a}}$ & $0.3 \pm 0.1^{\mathrm{b}}$ & $0.3 \pm 0.0^{\mathrm{b}}$ \\
\hline Valores com letras diferentes dentro de uma mesma coluna diferem significativamente $(\mathrm{P}<0.05)$
\end{tabular}

Na Tabela 12 estão os efeitos da dieta sobre a composição de ácidos graxos saturados (AGS), monoinsaturados (AGMI) e Poliinsaturados (AGPI). Os teores de ácidos graxos saturados foi mais elevado para os animais a pasto, sugerindo que as dietas dos animais em confinamento, com maior teor de ácidos graxos monoinsaturados estaria mais próxima do perfil ideal de ingestão de ácidos graxos para humanos (Dermeyer \& Doreau,1999). 
Um indicativo da atividade da delta-9-dessaturase, responsável pela produção de palmitoléico e oléico, a partir, respectivamente do palmítico e do esteárico pode ser inferida pelos dados da Tabela 12. Essa estimativa foi feita através de cálculo sugerido por Malau-Aduli et al. (1997). A relação entre esses ácidos também é apresentada. Animais a pasto apresentaram menor atividade da Delta-9 dessaturase, o que não era esperado em função das dietas fornecidas.

Tabela 12. Teores de ácidos graxos na carne bovina das diferentes sistemas de produção

$$
(g / 100 g)
$$

\begin{tabular}{|c|c|c|c|}
\hline & \multirow{3}{*}{$\begin{array}{c}\text { Pasto } \\
\text { Média } \pm d p\end{array}$} & \multicolumn{2}{|c|}{ Confinamento } \\
\hline & & Convencional & Alto Concentrado \\
\hline & & Média \pm dp & Média $\pm d p$ \\
\hline Saturados & $56.8 \pm 3.4^{\prime \prime}$ & $42.4 \pm 4.1^{b}$ & $41.8 \pm 1.8^{b}$ \\
\hline Monoinsaturados & $35.9 \pm 3.6^{b}$ & $50.7 \pm 2.6^{*}$ & $47.8 \pm 1.7^{\prime \prime}$ \\
\hline Poliinsaturados & $3.0 \pm 0.6^{b}$ & $2.9 \pm 0.9^{b}$ & $4.6 \pm 0.6^{\circ}$ \\
\hline$\Delta-9$ dessaturase em C16:0 $0^{I}$ & $7.4 \% \pm 1.0 \%{ }^{b}$ & $16.1 \% \pm 2.7 \%^{*}$ & $13.6 \% \pm 1.7 \%{ }^{\mathrm{a}}$ \\
\hline$\Delta-9$ dessaturase em C18: $0^{2}$ & $56.9 \% \pm 5.4 \%^{b}$ & $74.8 \% \pm 3.7 \%$ & $71.3 \% \pm 2.8 \%$ \\
\hline Relação C16:0/C16:1 & $12.75 \pm 1.86^{\circ}$ & $5.37 \pm 1.00^{b}$ & $6.45 \pm 0.81^{b}$ \\
\hline Relação C18:0/C18:1 & $0.77 \pm 0.16^{b}$ & $0.34 \pm 0.06^{b}$ & $0.40 \pm 0.06^{b}$ \\
\hline
\end{tabular}

C16:1/(C16:1+C16:0) $\times 100 ;{ }^{2} \mathrm{C} 18: 1 /(\mathrm{C} 18: 1+\mathrm{C} 18: 0) \times 100$

Duas condições ocorrem para explicar a maior percentagem de insaturados nos animais que receberam concentrado em confinamento: 1) A maior produção de propiônico aumenta a proporção de ácidos graxos insaturados nos depósitos corporais (Lawrence \& Fowler, 1997) e 2) O pH ruminal mais baixo observados nestas dietas diminuem a lipólise e a biohidrogenação ruminal de ácidos graxos (Sukhija e Palmquist, 1990; Dermeyer \& Doreau, 1999). Isso pode explicar, não somente a maior proporção de insaturados para animais confinados, mas também a maior quantidade de poliinsaturados nos animais de confinamento com alta proporçāo de concentrados em relação a dietas com maior proporção de volumosos. 
Tabela 13. Teores de ácido linoléico conjugado cis9, trans 11 na carne bovina de diferentes sistemas de produção (mg/g gordura).

\begin{tabular}{lccc}
\hline & \multicolumn{2}{c}{ Confinamento } \\
& Pasto & Convencional & Alto Concentrado \\
& Média $\pm \mathrm{dp}$ & Média $\pm \mathrm{dp}$ & Média $\pm \mathrm{dp}$ \\
\hline CLA 18:2 c9,t11 & $2.8 \pm 0.45^{\mathrm{b}}$ & $4.7 \pm 1.5^{\mathrm{b}}$ & $9.9 \pm 2.4^{\mathrm{a}}$ \\
\hline
\end{tabular}

Os teores de CLA observados são próximos dos obtidos por Chin et al. (1992) e por Bealieu e Drackley (2001). Não foi detectado, em nenhuma das amostras de carne, o isômero t10, c12. Todo o CLA determinado nestas amostras foi, portanto, ácido rumênico. Os valores obtidos foram surpreendentes, uma vez que os animais que apresentaram as maiores concentrações foram aqueles submetidos aos maiores teores de concentrado e os menores valores de CLA ficaram com os animais em pastejo. Os animais a pasto receberam um suplementação com concentrado, ainda sim, seria, das situações coletadas, aquela com maior relação volumoso:concentrado. Trabalhos na literatura mostram aumento de concentração de CLA com aumento de ingestão de forragem. Moloney \& Prench, (2001) alimentando novilhos com Lolium perene por 85 dias antes do abate, obtiveram aumento linear nos teores de CLA intra-muscular com a redução da proporção de concentrado na dieta, com consequente aumento de ingestão de pastagem. Naquele trabalho o valor mais baixo de CLA $(3,7 \mathrm{mg} / \mathrm{g}$ de gordura), foi obtido quando a relação volumoso:concentrado era 1:8 e o tratamento com pastejo e sem concentrado apresentou o valor mais alto $(10,8 \mathrm{mg} / \mathrm{g}$ gordura). Consistente com estes resultados, Sundquist et al. (2001) observaram menor teor de CLA no músculo do pescoço de novilhos alimentados por 3 meses com concentrados e pastagem cultivada, comparado ao grupo que se alimentou apenas de pastagem natural da região sudoeste da Suécia por 6 meses. Os animais alimentados exclusivamente com pastagem apresentaram teores mais elevados de CLA na fração fosfolipídica, com média de 7,6\% (faixa: 6,3 - 9,1\%) contra 4,42\% (faixa: 0 - 7,86\%), bem como na gordura total com média de 15,8 mg/g gordura (faixa 5,8 a $37 \mathrm{mg} / \mathrm{g}$ gordura) contra $3,9 \mathrm{mg} / \mathrm{g}$ gordura (faixa: 2 a 4,8 mg/g gordura) para o grupo com suplemento. Portanto o suplmento pode reduzir o teor de CLA. 
Outra possível explicação para os teores mais baixos de CLA nos animais alimentados a pasto no presente experimento poderiam ser duas outras diferenças que são a forragem tropical (Brachiaria decumbens) e a raça do animal (Nelore, B. indicus). Consistente com a hipótese de que estes fatores podem afetar negativamente o teor de CLA, os menores valores de CLA para leite nas Águas foram para animais Gir pastejando Braquiaria spp. Forragens tropicais, em geral, apresentam menores teores de C18:3 do que forragens temperadas e concentrações maiores de C16:0 (O’Kelly \& Reich, 1976; Bauchart et al., 1984). Este perfil de ácidos graxos das forragens torpicais, com menor proporção de ácidos de 18 carbonos e menor insaturação seria menos favorável à produção de CLA. Ainda sim, faltam dados do perfil de ácidos graxos de Braquiárias spp.

\subsection{Perfis de ácidos graxos da carne de monogástricos (Aves e Suínos)}

Para comparar os dados obtidos com os animais ruminantes, foram obtidos os perfis de ácidos graxos da carne de aves e suínos (Tabela 14).

A análise do perfil lipídico das amostras do l. Longissimus dorsi de suínos são similares a outros dados da literatura (Thiel-Cooper et al., 2001; Ramsay et al., 2001; Smith et al., 1996), exceto por uma quantidade bastante baixa de linoléico.

O perfil da gordura de frangos foi semelhante ao ao de Sanz et al. (2001) da gordura abdominal de frangos recebendo 3\% de óleo de girassol e $8 \%$ de sebo. Já Crespo e Esteve-Garcia (2001), analisando a gordura abdominal de animais recebendo sebo na dieta, observaram menores teores de linoléico $(8,35 \%)$. 
Tabela 14. Perfis de ácidos graxos da carne de Aves e Suínos (g/100g)

\begin{tabular}{lcc}
\hline & Suíno & Frango \\
& Média \pm dp & Média \pm dp \\
\hline C14:0 & $1.3 \pm 0.1$ & $0.7 \pm 0.1$ \\
C14:1 & ND & $0.3 \pm 0.0$ \\
C15:0 & ND & $0.1 \pm 0.0$ \\
C16:0 Total & $24.8 \pm 1.0$ & $22.5 \pm 1.5$ \\
C16:1 cis-9 & $2.2 \pm 0.6$ & $7.2 \pm 1.1$ \\
C17:0 & $0.4 \pm 0.1$ & $0.1 \pm 0.0$ \\
C17:1 & $0.3 \pm 0.0$ & $0.1 \pm 0.1$ \\
C18:0 & $15.6 \pm 1.7$ & $5.6 \pm 0.4$ \\
C18:1 trans- 11 & $0.0 \pm 0.0$ & $0.1 \pm 0.1$ \\
C18:1 cis-9 & $42.0 \pm 1.1$ & $38.2 \pm 1.3$ \\
C18:1 Total & $45.6 \pm 1.4$ & $40.7 \pm 1.3$ \\
C18:2 cis-9,cis- 12 & $6.4 \pm 0.5$ & $20.0 \pm 3.7$ \\
C18:2 Total & $6.5 \pm 0.5$ & $20.2 \pm 3.8$ \\
C18:3 & $0.7 \pm 0.1$ & $1.1 \pm 0.4$ \\
\hline
\end{tabular}

Tabela 15. Teores de ácido linoléico conjugado (CLA) da carne de aves e da carne de suínos (mg/g gordura).

\begin{tabular}{lcc}
\hline & $\begin{array}{c}\text { Suíno } \\
\text { Média } \pm \mathrm{dp}\end{array}$ & $\begin{array}{c}\text { Frango } \\
\text { Média } \pm \mathrm{dp}\end{array}$ \\
\hline CLA total, $\mathrm{mg} /$ g gordura & $0.22 \pm 0.2$ & $0.98 \pm 0.5$ \\
\hline
\end{tabular}

O teor de CLA em suínos é bem inferior aos de Bealieu \& Drackley (2001) para costelas de porco $(1,4 \mathrm{mg} / \mathrm{g}$ gordura) e os $0,6 \pm 0.06 \mathrm{mg} / \mathrm{g}$ gordura encontrado por Chin et al. (1992). Esses últimos não especificam o corte usado, mas relatam que o c9,t11 representou $82 \%$ do total de CLA. O teor de t10,c12 no presente trabalho foi menor que o limite de detecção. Thiel-Cooper et al. (2001) estudaram os efeitos da suplementação com CLA de dietas de milho e farelo de soja em porcos castrados (Yorkshire X Landrace X Duroc X Hampshire) abatidos com $116 \mathrm{~kg}$ de Peso Foram usadas doses crescentes de $0 ; 0.12$.; 0.25; 0.50 e 1,0\% na matéria seca de CLA-60 (12\% c9,t11 e 14\% t10,c12). Houve um aumento do teor de c9,t11, dependente da dose de CLA, com 
concentrações máximas de 21,6 mg/g de gordura e 3,7 mg/g de gordura, respectivamente para gordura subcutânea e gordura do tecido magro (músculo lombar). No tratamento controle, não foi detectado o c9,t11 para gordura subcutânea e um teor de 0,3 mg/g de gordura para a gordura extraída do tecido magro, valor este próximo ao obtido no presente trabalho. O t10,c12 não foi detectado para nenhum dos dois tecidos no tratamento controle, mas para a máxima dosagem resultou em $18,7 \mathrm{mg} / \mathrm{g}$ de gordura no tecido subcutâneo e 3,2 mg/ g de gordura para o lombo. A suplementação com CLA elevou os teores de CLA total na gordura a níveis muito mais elevados que os normalmente encontrados em suínos. Ramsay et al. (2001) trabalhou com uma mistura de CLA com composição diferente (25\% c9,t11 e 35\% c10,t12), mas níveis de inclusão na dieta semelhantes $(0 ; 0.25 ; 0.50 ; 1.0$ e $2.0 \%$ da matéria seca). Os porcos Yorkshire $X$ Landrace foram abatidos com $55 \mathrm{~kg}$ de Peso Vivo após recebererem, desde os $20 \mathrm{~kg}$ PV, dieta basal que incluía milho, farelo de soja, soro de leite seco $(2,0 \%)$ e óleo de milho (2,0\%), com os diferentes níveis de CLA. Para a dieta com 1\% de CLA as concentrações foram de 15 e $36 \mathrm{mg} / \mathrm{g}$ gordura, respectivamente para c9,t11 e c10,t12 e, para esses mesmos isômeros, a concentração máxima, observada para a dieta com $2 \%$ de CLA, foi de 36 e $61 \mathrm{mg} / \mathrm{g}$ gordura. Estes trabalhos demonstram que a suplementação com CLA na dieta é uma forma bastante eficiente de aumentar o teor de CLA na gordura de suínos.

O teor de CLA total em frango ficou bem próximo de Chin et al. (1992), que foi de $0.9 \pm 0.02 \mathrm{mg} / \mathrm{g}$ gordura. Naquele trabalho $84 \%$ do CLA era representado pelo isômero c9,t11. Os resultados deste trabalho são inferiores aos de Beaulieu \& Drackley (2001) que foi de $1,5 \mathrm{mg} / \mathrm{g}$ gordura. Du et al. (2002) reportam como zero o valor de concentração de CLA em amostras de filé de peito de frango consumindo uma dieta controle, sendo que estes teores foram para $33 \mathrm{mg} / \mathrm{g}$ gordura nos animais recebendo suplementação de $1 \%$ de CLA na dieta. 


\subsection{Comparação de todos os valores de CLA total}

$\mathrm{Na}$ Figura 5, são apresentados os teores de CLA total para os alimentos estudados, em ordem decrescente do teor deste, indicando a posição que cada uma das diferentes fontes ocupa como potenciais fornecedoras de CLA.

Pode ser observado, para CLA total, que as fontes de ruminantes foram as com concentrações mais elevadas, com apenas um teor inesperadamente baixo para carne bovina produzida a pasto (Barra 15) que, ainda sim, é numericamente superior às carnes de monogástricos. A média para as amostras de frango é cerca de $65 \%$ inferior ao menor valor de concentração para ruminantes, o valor para animais a pasto. Os valores encontrados para animais confinados com dietas de alto concentrado foram elevados. A gordura do leite, entretanto, é o alimento com teores mais elevados de CLA total. A média para suínos é a mais baixa de todos.

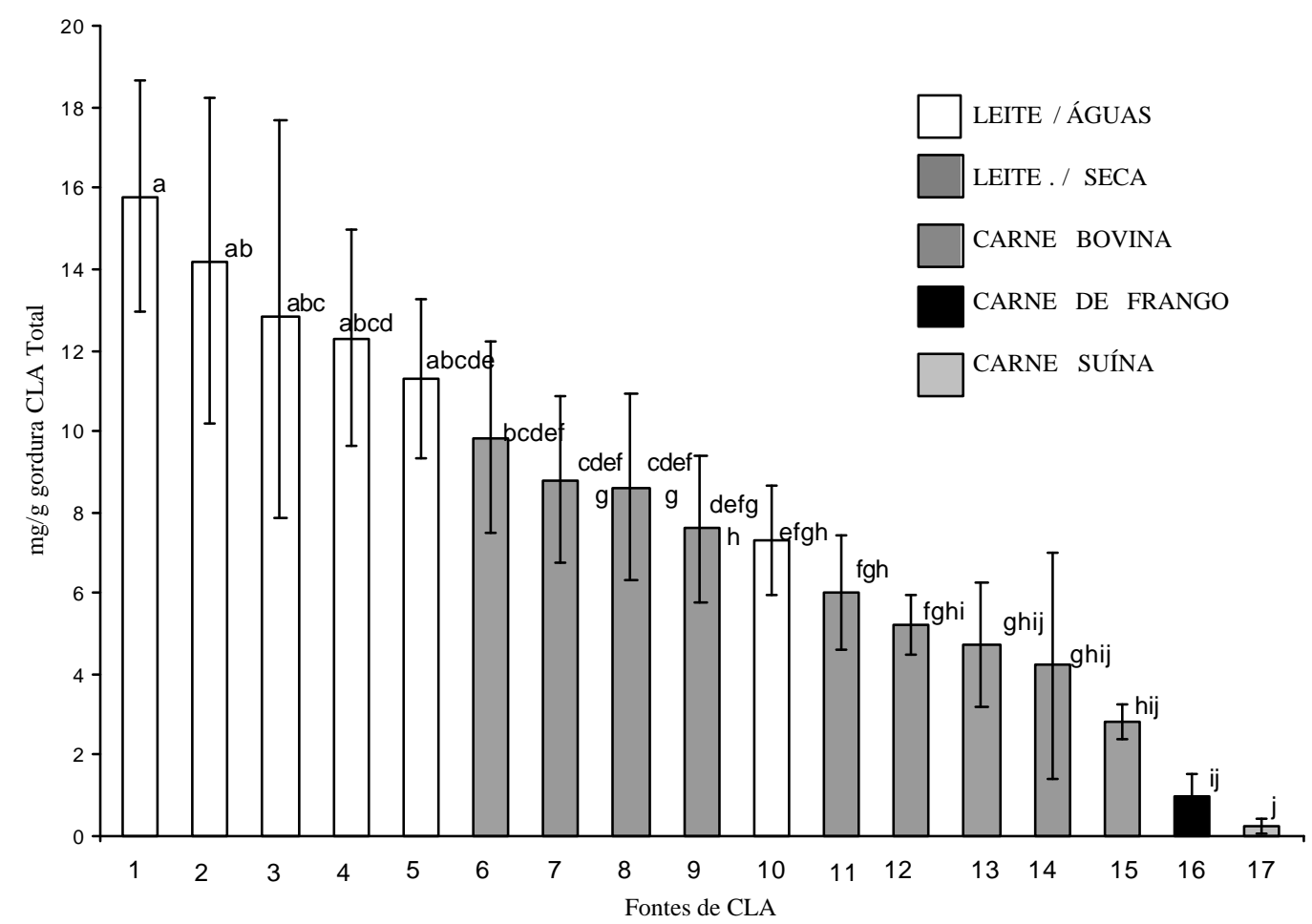

Figura 5 - Concentrações de ácido linoléico conjugado (CLA) total para todas as amostras de origem animal. Os números da barra correspondem a: 1=Leite 5; 2 
=Leite 1, 3=Leite 4; 4=Leite 6; 5=Leite 3; 6=Confinamento Alto Concentrado; 7=Leite 7; $8=$ Leite $8 ; 9=$ Leite $9 ; 10=$ Leite $2 ; 11=$ Leite 12;12=Leite 11;13=Confinamento Baixo Concentrado; 14=Leite 10;15=Carne de Frango e 16=Carne Suína. Para maiores detalhes sobre as fazendas de leite, ver Apêndice 1.

\subsection{A refeição total e os valores de CLA}

Na Tabela 16 estão os teores de CLA total em refeições típicas consumidas no Brasil. As dietas que apresentaram concentração de CLA detectáveis por nossa metodologia foram aquelas maiores que $0,3 \mathrm{mg} / \mathrm{g}$ de gordura:

Tabela 16. Descrição das dietas coletadas, tipo e peso das carnes (em matéria original) e valor de CLA total.

\begin{tabular}{|c|c|c|c|c|c|}
\hline Descrição & Carne & $\begin{array}{l}\text { Peso } \\
(\mathrm{g})\end{array}$ & Acompanhamento & $\begin{array}{l}\text { Peso } \\
\text { Total }^{1} \\
(\mathrm{~g})\end{array}$ & $\begin{array}{l}\text { CLA } \\
\text { TOTAL } \\
\text { (mg/g } \\
\text { gordura) }\end{array}$ \\
\hline Dieta 1 & Bife & 95 & $\begin{array}{l}\text { Arroz, feijão, chuchu } \\
\text { sauteé, alface }\end{array}$ & 326 & 3.1 \\
\hline Dieta 2 & $\begin{array}{l}\text { Peito de } \\
\text { frango com } \\
\text { osso }\end{array}$ & 230 & $\begin{array}{l}\text { Arroz, feijão, repolho, } \\
\text { rúcula, tomate, } \\
\text { berinjela }\end{array}$ & 465 & - \\
\hline Dieta 3 & Bife & 80 & $\begin{array}{c}\text { Arroz, feijão, couve, } \\
\text { pepino, beterraba, } \\
\text { couve }\end{array}$ & 410 & 4.9 \\
\hline Dieta 4 & Filé peixe & 100 & $\begin{array}{l}\text { Arroz, feijão, vagem } \\
\text { refogada,pepino, } \\
\text { alface, tomate }\end{array}$ & 580 & ND \\
\hline Dieta 5 & Lombo & 60 & $\begin{array}{l}\text { Arroz, feijão, farofa c/ } \\
\text { frutas, abobrinha ref., } \\
\text { repolho, rúcula, tomate }\end{array}$ & 405 & 0.9 \\
\hline
\end{tabular}

\footnotetext{
Peso Total $=$ Carne + Acompanhamento
}

ND - não detectado

Na dieta com peito de frango, não houve a quantidade mínima para detecção de CLA. As dietas que continham a carne bovina como fonte protéica apresentaram valores elevados de concentração de CLA, próximos àqueles reportados para carne in natura em 
países do hemisfério norte. Na Dieta 5, o valor de CLA total da dieta é bem mais alto que os valores encontrados neste trabalho.

$\mathrm{Na}$ Tabela 17, temos os teores de MS, a gordura total (como EE) das dietas, o valor de gordura, em gramas da die ta e o valor estimado de CLA que seria ingerido com consumo total desta refeição.

Tabela 17. Valores de MS, teor de gorduraDescrição das dietas coletadas, peso das carnes e do acompanhamento (em matéria original) e consumo diário de CLA total

\begin{tabular}{lcccc}
\hline & \% MS & \%Gordura & $\begin{array}{c}\text { Gordura } \\
(\mathrm{g})\end{array}$ & $\begin{array}{c}\text { CLA } \\
(\mathrm{mg})\end{array}$ \\
\hline Dieta 1 & 30.70 & 12.43 & 16 & 50 \\
Dieta 2 & 28.99 & 11.16 & 22 & ND \\
Dieta 3 & 27.86 & 16.23 & 22 & 109 \\
Dieta 4 & 23.89 & 10.86 & 18 & 0 \\
Dieta 5 & 28.24 & 10.37 & 14 & 12 \\
Dieta 6 & 27.96 & 7.68 & 12 & 0 \\
\hline
\end{tabular}

A estimativa de consumo total mostra que haveria consumo apreciável apenas para as dietas com carne bovina, apesar da grande diferença entre elas. Essa diferença estaria justificada pelas próprias análises de das amostras de carne. Com base no peso individual da carne e considerado que apenas ela contribui para o CLA da dieta total, estimaríamos concentrações de cerca de 3 a 6 mg/g gordura da carne da Dieta 1 e entre 7 e $13 \mathrm{mg} / \mathrm{g}$ gordura para a Dieta 2, caso a carne tivesse entre 20 e $10 \%$ de gordura total, respectivamente. Com cálculo semelhante e considerando que o lombo tivesse entre 10$15 \%$ de gordura total, o teor estimado de CLA total seria de 1,3 a 2,0 mg/ g gordura. Esses valores são mais altos do que o encontrado neste experimento, mas o valor inferior estaria próximo ao obtido para costelas de porco por Bealieu \& Drackley (2001). 


\subsection{Efeitos da suplementação com CLA de vacas lactantes em pastejo sobre a produção, composição de leite, parâmetros plasmáticos, peso e condição corporal.}

\subsubsection{Produção e composição do leite}

As vacas que consumiram o concentrado com CLA produziram maior volume de leite do que os animais do grupo Controle $(\mathrm{P}=0,056)$, como pode ser observado na Tabela 18, que contém os dados das concentrações dos componentes do leite, da energia secretada (MJ/dia) no leite e da densidade energética do leite ( $\mathrm{MJ} / \mathrm{kg}$ leite produzido).

Tabela 18. Produção e composição de leite de vacas recebendo Megalac (Controle) ou sais de cálcio de CLA-60 (CLA) dos $28^{\circ}$ aos $84^{\circ}$ dia em lactação

\begin{tabular}{|c|c|c|c|c|c|}
\hline & Controle & CLA & $\mathrm{dp}$ & Trat. & $\begin{array}{c}\text { Tempo X } \\
\text { Tratamento. }\end{array}$ \\
\hline Produção de Leite (kg/dia) & 15,2 & 16,3 & 0,2 & $\neq$ & $\mathrm{NS}$ \\
\hline Gordura, $\%$ & 2,86 & 2,05 & 0,04 & $* *$ & $* *$ \\
\hline Proteína, \% & 2,78 & 3,05 & 0,02 & $* *$ & $* *$ \\
\hline Lactose, $\%$ & 4,65 & 4,45 & 0,02 & $*$ & $*$ \\
\hline Sólidos Totais, \% & 11,02 & 10,35 & 0,05 & $* *$ & NS \\
\hline Gordura, kg & 0,437 & 0,349 & 0,006 & $* *$ & $* *$ \\
\hline Proteína, kg & 0,422 & 0,504 & 0,005 & $* *$ & $*$ \\
\hline Lactose, $\mathrm{kg}$ & 0,692 & 0,726 & 0,007 & NS & NS \\
\hline Sólidos Totais, kg & 1,662 & 1,716 & 0,017 & NS & NS \\
\hline $\mathrm{MJ} / \mathrm{dia}$ & 37,8 & 36,9 & 0,39 & NS & NS \\
\hline $\mathrm{MJ} / \mathrm{kg}$ & 2,500 & 2,270 & 0,02 & $* *$ & $* *$ \\
\hline
\end{tabular}

A concentração da gordura do leite foi deprimida (-28\%) nas vacas tratadas com CLA $(\mathrm{P}<0.001)$. Este efeito foi observado já com uma semana de tratamento quando as vacas tinham menos de 30 dias em lactação. O trabalho de suplementação feito com vacas de alta produção (Giesey et al., 1999), opostamente, apresentou efeito do tratamento apenas 3 semanas após o início da suplementação, cerca de 5 semanas pósparto. Isto pode estar relacionado com a maior importância relativa da síntese de gordura na glândula mamária destas vacas de baixa produção (i.e. acetato através da síntese de 
novo) em relação a vacas de alta produção, cuja lipogênse na glândula mamária utiliza em maior proporção os ácidos graxos pré-formados oriundos da dieta ou da mobilização do tecido adiposo. O período de tratamento deste experimento se iniciou com 28 DEL e o de Giesey et al. (1999) com 14 DEL. O valor de depressão da gordura neste trabalho é muito próximo do obtido por Chouinard et al. (1999), que infudiu no abomaso 28 g/dia de CLA-60. Pode-se tentar associar este valor com a quantidade que provavelmente chegou no abomaso das vacas deste experimento. Aparentemente os animais controle já apresentavam teores relativamente baixos de gordura do leite, provavelmente deprimidos por conta do uso da farinha de peixe e de um possível efeito do óleo de peixe na redução da gordura (Chilliard et al, 2001).

Houve interação tempo x tratamento para teor de gordura, aparentemente em função da primeira semana representar um transição até do tratamento (tempo zero) a até o efeito integral do tratamento (tempo zero). Todavia já a média das três determinações de gordura da primeira semana foi diferente para o CLA $(\mathrm{P}=0,03)$.

O teor de proteína do leite das vacas tratadas aumentou cerca de $10 \%$ $(\mathrm{P}=0.0065)$. De forma semelhante ao ocorrido para o teor de gordura, todas as semanas são significativamente diferentes entre os tratamentos para proteína $(\mathrm{P}<0.05)$, apenas sendo os valores das probabilidades diferentes entre as semanas. Associando este incremento no teor de proteína com a maior produção de leite das vacas suplementadas com CLA, a diferença na produção de proteína (kg/dia) para vacas tratadas foi ampliada para $19.4 \%(\mathrm{P}<0,001)$.

Os animais Controle tiveram teores de lactose significativamente mais altos que os animais com CLA, mais isso só ocorreu da terceira a oitava semana, sendo a diferença numericamente pequena. Contudo, é um resultado pouco usual, pela notória constância da lactose (Kennely et al., 1999) e talvez possa estar relacionado ao efeito osmótico do maior teor de proteína presente naquele leite. Os resultados sugerem que o efeito do CLA no metabolismo da glândula mamária pode ir além de uma mera inibição da lipogênse, mas uma alteração na regulação usual da glândula mamária em termos da concentração de macromoléculas nas secreções da glândula mamária. A drástica redução no teor de gordura nos animais tratados e esta pequena elevação no teor de lactose para os animais Controle resultou em um teor de sólidos totais maior para as vacas Controle 
$(\mathrm{P}<0,01)$. O aumento no teor de proteína compensou apenas parcialmente a queda nos sólidos das vacas tratadas com CLA ocorrida na gordura.

Os valores de produção de gordura foram significativamente diferentes entre os tratamentos e a quantidade de gordura produzida foi diminuída em $20 \%$ pela suplementação com CLA. Desdobrando o efeito dos tratamentos em cada semana, apenas a primeira semana não teve produção significativamente maior para Controle em relação ao CLA. Houve maior produção de proteína pelos animais que receberam CLA $(\mathrm{P}<0,015)$, em todas as semanas, mas enquanto a primeira o valor foi de $\mathrm{P}=0.045$, para as demais o P foi menor que 0,01 . O elevado aumento na produção de proteína pelo CLA, superior ao de Giesey et al. (1999) pode ter sido obtido em razão das quantidades adicionais de proteína metabolizável na dieta, o que compensaria o aumento nas exigências de aminoácidos.

A produção de lactose não diferiu entre os tratamentos, mas houve um aumento na produção de sólidos totais em função do aumento do teor de proteína e da maior produção de leite dos animais $(\mathrm{P}=0.056)$ com CLA. No caso da lactose, a falta de efeito foi função da compensação do menor teor de lactose pela maior produção de leite.

A concentração de energia do leite $(\mathrm{MJ} / \mathrm{kg})$ foi alterada pelo tratamento, com as vacas tratadas com CLA produzindo leite com menor concentração de energia $(\mathrm{P}<0.001)$ $\mathrm{O}$ valor de densidade energética do leite $(\mathrm{MJ} / \mathrm{kg})$, apresentou interação tempo $\mathrm{x}$ tratamento, pois apenas o valor da primeira semana não foi diferente entre os tratamentos. Este resultado é explicado pelos efeitos observados para gordura, lactose e proteína. A quantidade de energia secretada no leite não foi afetada pelo tratamento, pois, de acordo com a hipótese deste trabalho, as vacas compensaram a diminuição do teor de energia, secretando maior volume de leite, e este continha maiores teores de proteína. Os resultados sugerem que os efeitos do CLA, em vacas em ambientes desafiadores, onde o aporte de energia disponível é inferior ao necessário para as vacas atingirem seu potencial genético, é o de permitir a mesma secreção de energia. Uma vez que o leite contem menos gordura e mais proteína, mas com uma densidade energética menor, há portanto um aumento dos quilogramas de proteína e o volume de leite produzido. 
Na Tabela 19, os efeitos do tratamento com CLA são apresentados para as mesmas variáveis daos mesmos valores da Tabela 18, mas para o período residual, à partir dos $84 \mathrm{DEL}$, quando os animais deixaram de receber a gordura protegida e passaram a receber um dieta comercial convencional.

Tabela 19. Produção e composição de leite do $85^{\circ}$ ao $112^{\circ}$ dias em lactação (Período Residual) em vacas que receberam Megalac (Controle) ou sais de CLA-60 (CLA) entre os dias 28 ao 84 em lactação.

\begin{tabular}{|c|c|c|c|c|c|}
\hline & \multirow{2}{*}{$\begin{array}{c}\text { Controle } \\
\text { Média }\end{array}$} & \multicolumn{2}{|l|}{ CLA } & \multicolumn{2}{|c|}{$\mathrm{P}^{1}$} \\
\hline & & Média & $\mathrm{dp}$ & Tratamento & $\begin{array}{c}\text { Tempo X } \\
\text { Tratamento }\end{array}$ \\
\hline Produção de Leite (kg/dia) & 11,8 & 13,1 & 0,2 & $*$ & $\mathrm{NS}$ \\
\hline Gordura, $\%$ & 3,21 & 2,91 & 0,06 & $*$ & $*$ \\
\hline Proteína, \% & 2,85 & 3,06 & 0,02 & $* *$ & $*$ \\
\hline Lactose, \% & 4,52 & 4,43 & 0,03 & NS & $* *$ \\
\hline Sólidos Totais, \% & 11,21 & 11,13 & 0,08 & NS & $* *$ \\
\hline Gordura, kg & 0,387 & 0,411 & 0,008 & NS & $* *$ \\
\hline Proteína, kg & 0,335 & 0,398 & 0,006 & $* *$ & NS \\
\hline Lactose, $\mathrm{kg}$ & 0,526 & 0,574 & 0,009 & $\ddagger$ & NS \\
\hline Sólidos Totais, kg & 1,605 & 1,759 & 0,034 & $\neq$ & NS \\
\hline $\mathrm{MJ} / \mathrm{dia}$ & 31,178 & 34,317 & 0,54 & $\neq$ & $* *$ \\
\hline $\mathrm{MJ} / \mathrm{kg}$ & 2,643 & 2,634 & 0,026 & $\mathrm{NS}$ & $*$ \\
\hline
\end{tabular}

${ }^{1} \mathrm{P}<0,05=*, \mathrm{P}<0,01=* *, \mathrm{P}<0,10=\ddagger$

${ }^{2} \mathrm{dp}=$ desvio padrão

A porcentagem de gordura foi inferior, mas houve interação tratamento vs. tempo, sendo que os valores das 2 últimas semanas do experimento não foram estatisitcamente diferentes para teor de gordura entre os tratamentos. A retirada do CLA da dieta faz os valores de gordura voltarem aos níveis das vacas Controle. Os teores de proteína continuaram mais elevados após a retirada do CLA $(\mathrm{P}<0,01)$ com interação tempo vs tratamento. Apenas na última a diferença de teor de proteína desapareceu entre os tratamentos $(\mathrm{P}<0,10)$.

Para o teor de lactose, os dados não diferem entre os tratamentos. Para sólidos totais, apesar de ter havido tendência $(\mathrm{P}=0,06)$ a serem diferentes na primeira semana do período residual (semana 12), provavelmente em função da transição dos efeitos do CLA, as médias são iguais. 
Para densidade energética do leite $(\mathrm{MJ} / \mathrm{kg})$ as médias do período residual não diferem entre si. Entretanto, no tempo, a primeira semana do período residual (semana 12) é significativamente superior para os animais controle.

A secreção de energia (MJ/dia) foi afetada pelo tratamento anterior. A análise de variância, revela que houve diferença na anti-penúltima semana (semana 13) e tendência nas 2 últimas semanas a maior secreção de energia para CLA, com $\mathrm{P}=0,07$ e $\mathrm{P}=0,05$ para semanas 14 e 15. A explicação para a ausência de diferença na quantidade de energia secretada na semana 12 reside no fato da maior produção de leite dos animais com CLA ter sido compensada pela menor densidade energética do leite produzido, ainda sob o efeito residual do CLA reduzindo o teor de gordura. Nesta primeira semana pós CLA, a produção de energia pelos animais controle é maior $(\mathrm{P}=0,02)$. Entretanto, a última semana do período residual $\left(15^{\mathrm{a}}\right)$, esta secreção de energia tende a ser maior para os animais que receberam CLA $(\mathrm{P}=0,08)$, uma vez que o teor de gordura já havia voltado a níveis semelhantes aos do controle, mas a produção manteve-se maior. Para produção de proteína, houve efeito residual da suplementação de CLA, sendo que este é uma combinação de maior teor de proteína e maior volume de leite. A produção de lactose e sólidos totais tenderam a ser menores para as vacas Controle no período residual, devido a maior produção de leite dos animais que receberam CLA.

O aumento na produção de leite durante a suplementação com CLA está associado a redução na demanda de energia por unidade de leite, uma vez que um leite menos calórico foi produzido. A depressão da gordura do leite deixou de existir dentro de duas semana após o término do fornecimento de CLA. Entretanto, durante o período residual as vacas tratadas com CLA produziram 10,5\% mais leite. Essa maior produção após a remoção do CLA foi provavelmente causada por um maior pico de produção de leite obtido por este grupo de animais ainda durante o período de tratamento.

Houve uma melhora na persistência da lactação (Figura 6), com as inclinações das curvas de lactação diferentes para os animais recebendo CLA $(\mathrm{P}<0.05)$, incluindo os resultados do período de tratamento e das duas primeiras semanas do período residual. Analisando a Figura 6 percebe-se que do $98^{\circ}$ aos $112^{\circ}$ dias (duas últimas semanas do experimento) há uma aproximação das médias de produção das vacas que receberam CLA no período de tratamento em direção aos valores inferiores das vacas Controle. Há 
uma coincidência entre esses resultados e o dos teores de gordura, que foram iguais entre os tratamentos nas duas últimas semanas. Isso sugere que na medida que o leite produzido aproximava de uma mesma composição entre os tratamentos, o volume de produção tenderia a se igualar.

Estes resultados de produção e composição do leite são consistentes com as hipóteses propostas de que é possível manipular a composição do leite de forma a ter significativo efeito sobre as exigências e a produtividade da vaca de leite em ambientes desafiadores.

\subsubsection{Peso e condição corporal}

Os efeitos dos tratamentos sobre a condição corporal (CC) e peso vivo em jejum $(P V j=P V \times 0,93)$ podem ser vistos na Tabela 20. Não houve efeito da suplementação de CLA na CC das vacas. O comportamento do PVj, sem efeito do tratamento, está de acordo com a observação para a CC. Os baixos escores de condição corporal no início poderiam ter favorecido a recuperação de condição corporal. Entretanto, a ausência de recuperação está de acordo com o experimento ter sido feito no início da lactação e dos animais com CLA terem produzido mais leite. Os resultados são consistentes com os animais estarem em um ambiente onde o aporte de energia não era suficiente para permitir reposição de reservas corporais. Alguns autores sugerem que o CLA poderia inibir a síntese de gordura no tecido adiposo, entretanto a concentração de CLA necessária para afetar a lipogênese mamária é várias vezes menor daquela para inibir a lipogênese do que no tecido adiposo (Bauman, 2001). Portanto, podemos sugerir que não se esperaria efeito inibitório do CLA na síntese de gordura. Embora, apenas um outro experimento de longa duração com CLA tenha avaliado a CC, é possível sugerir o contrário, ou seja que em vacas em lactação o CLA possa permitir uma maior utilização da energia da dieta para deposição de reservas. Giesy et al. (1999) observaram um efeito do CLA (127g de um produto igual ao utilizado neste experimento) que aumentou a reposição da condição corporal e do peso em vacas produzindo 50 litros de leite por dia. 
Tabela 20. Peso Vivo em Jejum e Escore de Condição Corporal do $28^{\circ}$ ao $84^{\circ}$ dia em lactação (Período de Tratamento) dos animais recebendo Megalac (Controle) ou sais de cálcio de CLA-60 (CLA) e dos 85 aoa 112 dias em lactação (Período Residual)

\begin{tabular}{|c|c|c|c|c|}
\hline & \multicolumn{2}{|c|}{ Controle } & \multicolumn{2}{|c|}{ CLA } \\
\hline & Média & $\mathrm{dp}$ & Média & $\mathrm{dp}$ \\
\hline & \multicolumn{4}{|c|}{ Período de Tratamento } \\
\hline Escore de Condição Corporal ${ }^{1}$ & 3,7 & 0,05 & 3,9 & 0,07 \\
\hline \multirow[t]{2}{*}{ Peso Vivo, $\mathrm{kg}$} & 439,1 & 5,5 & 450,8 & 2,6 \\
\hline & \multicolumn{4}{|c|}{ Período Residual } \\
\hline Escore de Condição Corporal ${ }^{1}$ & 3,7 & 0,07 & 3,9 & 0,08 \\
\hline Peso Vivo, $\mathrm{kg}$ & 440,3 & 8,07 & 456,6 & 3,76 \\
\hline
\end{tabular}

${ }^{1}$ Escala de 1 a 9 (NRC, 1996) 


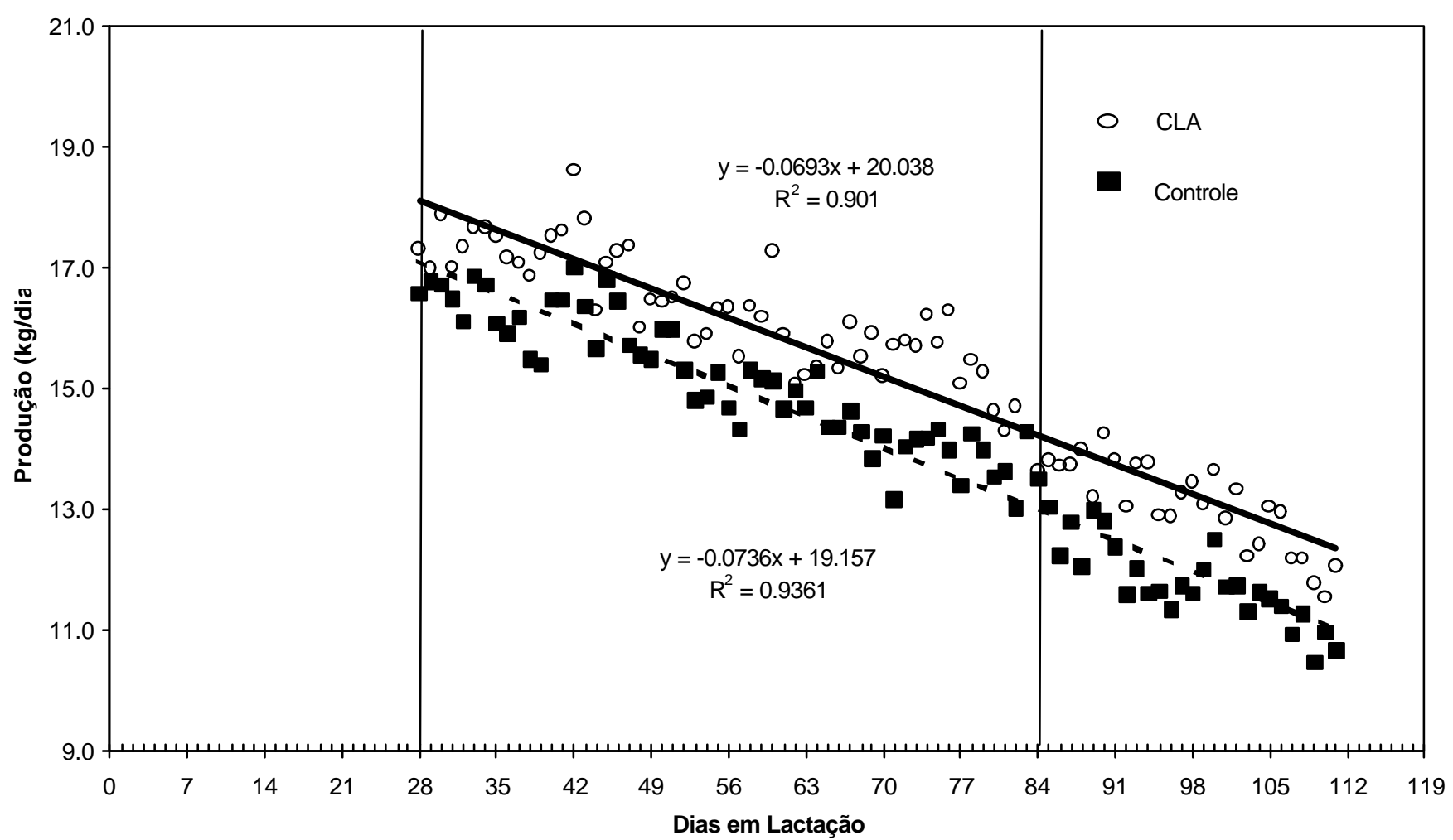

Figura 6 - Dispersão dos dados e regressões da produção de leite das vacas durtante o experimento, médias diárias. A equação de regressão superior é dos animais que receberam CLA no período de tratamento e, a outra, daqueles que receberam Megalac (Controle) 


\subsubsection{Perfil de ácidos graxos do leite}

As alterações ocorridas pela suplementação de CLA na foram de sais de cálcio no perfil de ácidos graxos (Tabela 21) foram consistentes com a ação do CLA no metabolismo de lipídeos. Foram observadas diferenças para C 4:0, C 6:0, C 8:0 e C10:0, nos dois períodos de coleta, com valores menores para os animais recebendo CLA. O C12:0 tendeu a ser menor para o CLA na primeira coleta $\left(42^{\circ}\right.$ ao $46^{\circ}$ DEL) e foi significativamente diferente na coleta entre o $70^{\circ}$ ao $74^{\circ}$ DEL. O C16:0 foi também foi menor na primeira coleta, mas não na segunda. O C16:0 no leite pode ser proveniente da dieta e da mobilização de tecidos ou síntese de novo. com o Isto pode estar ligado a menor importância relativa avançar da lactação. As diferenças encontradas sugerem um alteração na importância relativa destas vias em função do estágio de lactação e do CLA.

O C16:1 c9 foi maior para os animais do tratamento com CLA, embora no primeiro período isto não tenha sido significativo. Este resultado foi surpreendente, visto que há vários relatos de inibição da $\Delta-9$ dessaturase pela ação do CLA. Há ainda maiores teores de C18:2 t(n-6) e linolênico na primeira coleta para o tratamento com CLA, além de menores teores para C18:1. A razão para esta discrepância não está clara, mas pode envolver as condições deste experimento incluindo a presença da farinha de peixe, o nível de produção, o aporte de alimentos e a diferentes resistências a biohidrogenação dos suplementos de gordura

No período residual, só há pequenas diferenças entre o C16:0 e o C16:1. Para todos os demais, as diferenças entre os tratamentos desapareceu no período residual. Isto deixa claro que a alteração ocorreu devido aos efeitos do tratamento. 
Tabela 21. Perfil de ácidos graxos do leite de vacas recebendo Megalac (Controle) ou CLA-60 (CLA) do $28^{\circ}$ ao $84^{\circ}$ dias em lactação (Período de Tratamento) e dos 85 aos 112 dias em lactação (Período Residual).

\begin{tabular}{|c|c|c|c|c|c|c|c|c|c|c|}
\hline \multirow[t]{3}{*}{$\begin{array}{l}\text { Ácidos } \\
\text { Graxos }\end{array}$} & \multicolumn{3}{|c|}{$\begin{array}{l}\text { Período de } \\
\text { Tratamento } 1^{1}\end{array}$} & \multicolumn{3}{|c|}{$\begin{array}{c}\text { Período de } \\
\text { Tratamento } 2^{1}\end{array}$} & \multicolumn{3}{|c|}{ Período Residual } & \multirow[b]{3}{*}{$\mathrm{dp}$} \\
\hline & Controle & CLA & & Controle & CLA & & Controle & CLA & & \\
\hline & Média & Média & $\mathrm{P}^{2}$ & Média & Média & $\mathrm{P}$ & Média & Média & $\mathrm{P}$ & \\
\hline C 4:0 & 3,59 & 2,67 & $* *$ & 3,28 & 2,15 & $* *$ & 3,69 & 3,52 & NS & 0,06 \\
\hline C 6:0 & 1,93 & 1,23 & $* *$ & 1,95 & 1,15 & $* *$ & 2,07 & 1,97 & NS & 0,05 \\
\hline C 8:0 & 0,98 & 0,59 & $* *$ & 1,03 & 0,59 & $* *$ & 1,07 & 1,02 & NS & 0,03 \\
\hline C10:0 & 1,84 & 1,25 & $* *$ & 2,02 & 1,29 & $* *$ & 2,07 & 1,98 & NS & 0,56 \\
\hline $\mathrm{C} 12: 0$ & 2,10 & 1,77 & $ま$ & 2,39 & 1,87 & $*$ & 2,42 & 2,37 & NS & 0,06 \\
\hline C14:0 & 7,71 & 7,47 & NS & 8,67 & 8,40 & NS & 9,64 & 9,51 & NS & 0,17 \\
\hline C14:1 & 0,86 & 0,83 & NS & 0,96 & 0,99 & NS & 1,29 & 1,35 & NS & 0,03 \\
\hline C15:0 & 0,96 & 1,12 & $*$ & 1,07 & 1,13 & $\neq$ & 1,19 & 1,15 & NS & 0,02 \\
\hline C16:0 & 26,34 & 25,53 & $* *$ & 26,90 & 26,98 & NS & 25,65 & 26,78 & $*$ & 0,17 \\
\hline C16:1 c9 & 1,39 & 1,47 & NS & 1,26 & 1,56 & $*$ & 1,37 & 1,59 & $*$ & 0,03 \\
\hline C18:0 & 10,73 & 11,06 & NS & 12,16 & 12,32 & NS & 11,94 & 11,21 & NS & 0,18 \\
\hline C18:1 & 38,04 & 40,32 & $ま$ & 34,38 & 37,16 & $*$ & 35,40 & 35,14 & NS & 0,43 \\
\hline C18:2 t(n-6) & 0,11 & 0,14 & $* *$ & 0,10 & 0,12 & $* *$ & 0,11 & 0,32 & NS & 0,02 \\
\hline C18:2 c(n-6) & 1,73 & 1,81 & NS & 1,37 & 1,34 & NS & 1,52 & 1,58 & NS & 0,04 \\
\hline C18:3 (n-3) & 0,41 & 0,44 & $*$ & 0,41 & 0,40 & NS & 0,51 & 0,52 & NS & 0,08 \\
\hline $\mathrm{CLA}^{3}$ & 1,75 & 2,27 & $* *$ & 1,34 & 1,74 & $* *$ & 1,77 & 1,93 & NS & 0,05 \\
\hline c9,t11 & 1,45 & 1,72 & $* *$ & 1,11 & 1,25 & $\neq$ & 1,60 & 1,64 & NS & 0,04 \\
\hline $\mathrm{T} 10, \mathrm{c} 12$ & 0,04 & 0,08 & $* *$ & 0,03 & 0,05 & $* *$ & 0,03 & 0,03 & NS & 0,002 \\
\hline C 20:4 (n-6) & 0,08 & 0,06 & $*$ & 0,08 & 0,06 & $* *$ & 0,06 & 0,06 & NS & 0,002 \\
\hline C 20:1 & 0,11 & 0,14 & $ま$ & 0,21 & 0,21 & NS & 0,21 & 0,23 & NS & 0,011 \\
\hline C $20: 4(n-3)$ & 0,04 & 0,04 & NS & 0,08 & 0,09 & NS & 0,03 & 0,03 & NS & 0,003 \\
\hline C $20: 5$ (n-3) & 0,04 & 0,03 & $*$ & 0,03 & 0,02 & $*$ & 0,03 & 0,03 & NS & 0,001 \\
\hline C $22: 5(n-3)$ & 0,11 & 0,11 & NS & 0,10 & 0,10 & NS & 0,12 & 0,13 & NS & 0,011 \\
\hline C 22:6 (n-3) & 0,10 & 0,06 & $* *$ & 0,06 & 0,22 & NS & 0,05 & 0,05 & NS & 0,02 \\
\hline
\end{tabular}

${ }^{\top}$ Período de tratamento 1, leite coletado do dia 42-47; Período de Tramento 2, leite coletado do dia 7074.;

${ }^{2} \mathrm{P}<0,05=*, \mathrm{P}<0,01=* *, \mathrm{P}<0,10=\ddagger$

${ }^{3}$ Soma de $\mathrm{c} 9, \mathrm{t} 11$ e t10,c12 
Na Tabela 22, são apresentados os valores para vários isômeros dos ácidos graxos octadecenóicos (C18:1).

Tabela 22. Perfil de ácidos graxos C18:1 do leite de vacas recebendo Megalac (Controle) ou CLA-60 (CLA) do $28^{\circ}$ aos 84 dias em lactação (Período de Tratamento) e do $85^{\circ}$ aos $112^{\circ}$ dias em lactação (Período Residual).

\begin{tabular}{|c|c|c|c|c|c|c|c|c|c|c|}
\hline \multirow{2}{*}{$\begin{array}{l}\text { Ácido } \\
\text { Graxo } \\
\text { g/100g }\end{array}$} & \multicolumn{3}{|c|}{$\begin{array}{l}\text { Período de } \\
\text { Tratamento } 1\end{array}$} & \multicolumn{3}{|c|}{$\begin{array}{l}\text { Período de } \\
\text { Tratamento } 2^{1}\end{array}$} & \multicolumn{3}{|c|}{ Período Residual e } & \multirow[b]{2}{*}{$d p$} \\
\hline & Control & CLA & $\mathrm{P}$ & Controle & CLA & $\mathrm{P}$ & & CLA & $\mathrm{P}$ & \\
\hline C18:1 t9 & 2,95 & 3,11 & NS & 3,27 & 4,01 & $* *$ & 2,50 & 2,59 & $\mathrm{NS}$ & 0,08 \\
\hline C18:1 t10 & 0,61 & 0,76 & . & 0,63 & 0,64 & NS & 0,41 & 0,37 & NS & 0.08 \\
\hline C18:1 t11 & 3,58 & 4,14 & $*$ & 3,63 & 3,87 & NS & 3,54 & 3,56 & NS & 0,08 \\
\hline C18:1 c9 & 28,33 & 29,4 & NS & 24,68 & 25,91 & NS & 27,12 & 26,69 & NS & 0,34 \\
\hline $\begin{array}{c}\text { C } 18: 1 \\
\text { c11 }\end{array}$ & 1,25 & 1,38 & $T+$ & 1,10 & 1,24 & $* *$ & 0,89 & 0,86 & NS & 0,03 \\
\hline C $18: 1 \mathrm{t} 12$ & 0,28 & 0,34 & $* *$ & 0,30 & 0,37 & $* *$ & 0,27 & 0,26 & NS & 0,006 \\
\hline C $18: 1 \mathrm{t} 13$ & 0,18 & 0,21 & $* *$ & 0,18 & 0,23 & $* *$ & 0,14 & 0,14 & NS & 0,0004 \\
\hline C $18: 1 \mathrm{t} 16$ & 0,66 & 0,78 & $* *$ & 0,53 & 0,61 & $*$ & 0,46 & 0,48 & NS & 0,02 \\
\hline $\begin{array}{c}\text { C } 18: 1 \\
\text { c15 }\end{array}$ & 0,14 & 0,15 & $\neq$ & 0,14 & 0,16 & $* *$ & 0,11 & 0,10 & NS & 0,003 \\
\hline
\end{tabular}

${ }^{\top}$ Período de tratamento 1, leite coletado do $42^{\circ}$ ao $47^{\circ}$ dia da lactação; Período de Tramento 2, leite coletado do dia $70^{\circ}$ ao $74^{\circ}$ dia da lactação

${ }^{2} \mathrm{P}<0,05=*, \mathrm{P}<0,01=* *, \mathrm{P}<0,10=\neq$

Os valores para os ácidos C18:1 foram sempre mais elevados para os animais suplementados com CLA. Isso pode ser reflexo da diminuição da síntese de novo e do consequente aumento da proporção dos ácidos graxos de cadeia longa, mas a magnitude deste efeito sugere que há outros possíveis efeitos observados: 1) O perfil de ácidos graxos do CLA-60 é rico em diversos isômeros do CLA e 2) Pela natureza de poliinsaturados, deve ter havido dissociação e biohidrogenação destes no rúmen (Suhkija e Palmquist, 1990). Também é preciso notar que a dieta deste experimento continha uma proporção elevada de farinha de peixe e que praticamente inexistem resultados de pesquisa com forrageiras tropicais e sua associação com concentrados no rúmen. 
Tabela 23. Composição dos Perfis de ácidos graxos do leite das vacas recebendo Megalac (Controle) ou CLA-60 (CLA) do 28 aos 84 dias em lactação (Período de Tratamento) e do $85^{\circ}$ ao $112^{\circ}$ dia em lactação (Período Residual) separados por tipo de ligação e tamanho da cadeia.

\begin{tabular}{|c|c|c|c|c|c|c|c|c|c|c|}
\hline \multirow{2}{*}{$\begin{array}{c}\text { Ácidos Graxos } \\
\text { g/100g }\end{array}$} & \multicolumn{3}{|c|}{ Período de Tratamento } & \multicolumn{3}{|c|}{$\begin{array}{l}\text { Período de Tratamento } \\
\qquad 2^{1}\end{array}$} & \multicolumn{4}{|c|}{ Período Residual } \\
\hline & Controle & CLA & $\mathrm{P}^{2}$ & Controle & CLA & $\mathrm{P}^{2}$ & Controle & CLA & $\mathrm{P}$ & $d p$ \\
\hline Cadeia Curta & 10,44 & 7,51 & $* *$ & 10,68 & 7,05 & $* *$ & 11,33 & 10,86 & NS & 0.22 \\
\hline Cadeia Média & 37,26 & 36,41 & NS & 38,86 & 39,06 & NS & 39,14 & 40,37 & NS & 0.30 \\
\hline Cadeia Longa & 53,23 & 56,46 & $*$ & 50,29 & 53,58 & $*$ & 51,58 & 51,46 & NS & 0.43 \\
\hline Saturados & 56,18 & 52,69 & $* *$ & 59,48 & 55,87 & $* *$ & 59,75 & 59,50 & NS & 0.38 \\
\hline Insaturados & 43,36 & 46,33 & $*$ & 39,09 & 42,38 & $*$ & 40,93 & 41,71 & NS & 0.40 \\
\hline Monoinsaturados & 40,40 & 42,76 & $ま$ & 36,79 & 39,92 & $*$ & 38,25 & 38,82 & NS & 0.38 \\
\hline Poliinsaturados & 4,35 & 4,94 & $* *$ & 3,56 & 3,89 & $*$ & 4,05 & 4,36 & NS & 0.07 \\
\hline
\end{tabular}

Nas coletas, no período de tratamento, a porcentagem de AGCC foi inferior para os animais tratados (Tabela 23). Estas alterações no tamanho de cadeia dos ácidos graxos são consistentes com os efeitos do CLA na redução da lipogênese de novo, a partir de ácido acético e butírico na glândula mamária. Vários autores encontraram resultados semelhantes (Loor \& Herbein, 1998; Griinari et al, 1998; Chouinard et al, 1999). Consequência desta diminuição, a porcentagem dos AGCL, são mais elevados para os animais tratados (Tabela 23, P<0,01). Entretanto, isto não significa que o CLA não iniba a síntese de ácidos graxos de cadeia longa, como pode ser observado na Tabela 24, onde a produção de C18:0, C18:1 e C18:2c(n-6) foram reduzidas pelo CLA ( $\mathrm{P}<0,01)$, sendo que estes ácidos graxos são quase que exclusivamente secretados no leite a partir dos ácidos graxos pré-formados da dieta ou provenientes da mobilização das reservas corporais. 
Tabela 24. Produção de ácidos graxos do leite (gramas por dia) do leite das vacas recebendo Megalac (Controle) ou sais de cálcio de CLA-60 (CLA) do 28 aos $84^{\circ}$ dias em lactação (Período de Tratamento) e do $85^{\circ}$ aos $112^{\circ}$ dias em lactação (Período Residual).

\begin{tabular}{|c|c|c|c|c|c|c|c|c|c|c|}
\hline $\begin{array}{l}\text { Ácidos } \\
\text { Graxos }\end{array}$ & \multicolumn{3}{|c|}{$\begin{array}{l}\text { Período de } \\
\text { Tratamento } 1^{1}\end{array}$} & \multicolumn{3}{|c|}{$\begin{array}{l}\text { Período de } \\
\text { Tratamento } 2^{1}\end{array}$} & \multicolumn{3}{|c|}{ Período Residual } & \\
\hline didi & Controle & CLA & & Controle & CLA & & Controle & CLA & & \\
\hline & Média & Média & $\mathrm{P}^{2}$ & Média & Média & $\mathrm{P}$ & Média & Média & $\mathrm{P}$ & $\mathrm{dp}$ \\
\hline C 4:0 & 16,2 & 9,0 & $* *$ & 14,8 & 7,34 & $* *$ & 14,47 & 15,35 & NS & 3,59 \\
\hline C 6:0 & 8,7 & 4,1 & $* *$ & 8,82 & 3,88 & $* *$ & 8,13 & 8,60 & NS & 2,34 \\
\hline C 8:0 & 4,4 & 2,0 & $* *$ & 4,67 & 2,00 & $* *$ & 4,20 & 4,63 & NS & 1,36 \\
\hline C 10:0 & 8,3 & 4,2 & $* *$ & 9,13 & 4,35 & $* *$ & 8,13 & 8,63 & NS & 2,71 \\
\hline C 12:0 & 9,5 & 6,0 & $* *$ & 10,80 & 6,31 & $* *$ & 9,48 & 10,33 & NS & 2,83 \\
\hline C $14: 0$ & 34,9 & 25,3 & $* *$ & 39,19 & 28,38 & $* *$ & 37,80 & 41,45 & $*$ & 7,88 \\
\hline C $14: 1$ & 3,9 & 2,8 & $* *$ & 4,32 & 3,34 & $*$ & 5,04 & 5,87 & $*$ & 1,35 \\
\hline C 15:0 & 4,3 & 3,8 & NS & 5,01 & 3,83 & $* *$ & 4,64 & 5,01 & $* *$ & 0,74 \\
\hline C $16: 0$ & 119,1 & 86,3 & $* *$ & 121,60 & 91,19 & $* *$ & 100,55 & 116,75 & $* *$ & 15,04 \\
\hline C $16: 1$ c9 & 6,3 & 5,0 & $* *$ & 5,69 & 5,26 & NS & 5,38 & 6,91 & $* *$ & 1,27 \\
\hline C 18:0 & 48,5 & 37,4 & $* *$ & 54,97 & 41,63 & $* *$ & 46,79 & 48,85 & NS & 8,45 \\
\hline C $18: 1$ & 171,9 & 136,27 & $* *$ & 155,4 & 125,6 & $* *$ & 138,76 & 155,49 & $* *$ & 20,36 \\
\hline C $18: 2$ t(n-6) & 0,51 & 0,46 & $*$ & 0,45 & 0,40 & $* *$ & 0,41 & 0,47 & $\neq$ & 0,09 \\
\hline C18:2 c(n-6) & 7,81 & 6,11 & $* *$ & 6,21 & 4,52 & $* *$ & 5,96 & 6,62 & $*$ & 1,27 \\
\hline C $18: 3(n-3)$ & 1,83 & 1,66 & $* *$ & 1,86 & 1,62 & $* *$ & 1,99 & 2,12 & $*$ & 0,39 \\
\hline $\mathrm{CLA}^{3}$ & 7,89 & 7,78 & NS & 6,05 & 5,95 & NS & 7,35 & 7,89 & $\neq$ & 1,59 \\
\hline $\mathrm{c} 9, \mathrm{t} 11$ & 6,57 & 6,2 & $*$ & 5,02 & 4,64 & $\neq$ & 6,25 & 6,71 & $\neq$ & 1,52 \\
\hline $\mathrm{t} 10, \mathrm{c} 12$ & 0,16 & 0,22 & $* *$ & 0,12 & 0,14 & $* *$ & 0,12 & 0,12 & NS & 0,07 \\
\hline C $20: 4$ (n-6) & 0,34 & 0,28 & $* *$ & 0,34 & 0,23 & $* *$ & 0,22 & 0,24 & $\neq$ & 0,09 \\
\hline C 20:1 & 0,50 & 0,49 & NS & 0,93 & 0,82 & $* *$ & 0,82 & 0,90 & NS & 0,39 \\
\hline C $20: 4(n-3)$ & 0,20 & 0,17 & $*$ & 0,38 & 0,27 & $* *$ & 0,11 & 0,12 & NS & 0,09 \\
\hline C $20: 5(n-3)$ & 0,17 & 0,14 & $* *$ & 0,13 & 0,10 & $* *$ & 0,11 & 0,12 & NS & 0,05 \\
\hline C $22: 5(n-3)$ & 0,48 & 0,42 & $*$ & 0,43 & 0,39 & NS & 0,48 & 0,53 & NS & 0,43 \\
\hline C $22: 6(n-3)$ & 0,43 & 0,31 & $* *$ & 0,27 & 0,21 & $* *$ & 0,18 & 0,20 & NS & 0,13 \\
\hline
\end{tabular}

${ }^{\mathrm{C}}$ Período de tratamento 1, leite coletado do dia 42-47; Período de Tramento 2, leite coletado do dia 7074.;

${ }^{2} \mathrm{P}<0,05=*, \mathrm{P}<0,01=* *, \mathrm{P}<0,10=$ ₹

${ }^{3}$ Soma de $\mathrm{c} 9, \mathrm{t} 11$ e t10,c12 
Os ácidos graxos de cadeia curta são basicamente saturados, sendo que a redução na sua síntese tende a aumentar o grau de insaturação do leite.

Uma esperada diferença entre os monoinsaturados pela inibição da delta-9dessaturase talvez não tenha ocorrido pois o C20:5 (EPA), usualmente presente no óleo de peixe, também teriam essa característica (Chilliard et al., 2001). Ele, outros ácidos graxos poliinsaturados do óleo de peixe, inibiriam a síntese de novo tembém mas, ao que indica estes resultados, menos intensamente que o t10,c12 (Xu et al, 2001). Os ácidos graxos de cadeia curta são basicamente saturados, sendo que a redução na sua síntese tende a aumentar o grau de insaturação do leite.

Apesar do efeito inibitório do CLA ter sido observado para a produção de praticamente todos os ácidos graxos o efeito maior para a diferenciação da produção dos ácidos graxos de um tratamento em relação ao outro, são decorrentes da menor produção de gordura pelos animais tratados com CLA. O CLA total e o c9,t11, apesar da grande diminuição de produção de gordura, foram compensado pelo maior teor nos animais suplementados. A produção de t10,c12 foi mais elevada para as vacas tratadas que o dos animais controle com CLA-60. É notável que a recuperação do C18:2 t10,c12 no leite dos animais tratados com CLA60, aproximadamente 0,2 gramas por dia, representa cerca de $1 \%$ do C18:2 t10,c12 fornecido no suplemento. Estes resultados são consistentes com a proposta de que este isômero é ativamente metabolizado no animal.

Os dados de secreção diária no leite produção individual, mas especificamente para os ácidos graxos octadecenóicos, com destaque para os ácidos graxos com configuração trans, podem ser vistos na Tabela 25. Nota-se uma redução da secreção de todos estes ácidos, inclusive o vaccênico, embora uma redução que foi inferior para este ácido em relação à inibição da produção de gordura em geral (Tabela 23). 
Tabela 25. Produção diária de ácidos graxos (gramas) C18:1 do leite de vacas recebendo Megalac (Controle) ou sais de cálcio de CLA-60 (CLA) dos 28 aos 84o dias em lactação (Período de Tratamento) e dos 85 aos 112 dias em lactação (Período Residual).

\begin{tabular}{|c|c|c|c|c|c|c|c|c|c|c|}
\hline \multirow{2}{*}{$\begin{array}{l}\text { Ácido } \\
\text { Graxo } \\
\text { g/dia }\end{array}$} & \multicolumn{3}{|c|}{$\begin{array}{l}\text { Período de } \\
\text { Tratamento } 1\end{array}$} & \multicolumn{3}{|c|}{$\begin{array}{l}\text { Período de } \\
\text { Tratamento } 2^{1}\end{array}$} & \multicolumn{3}{|c|}{ Período Residual e } & \multirow[b]{2}{*}{$\mathrm{dp}$} \\
\hline & Control & CLA & $\mathrm{P}$ & Controle & CLA & $\mathrm{P}$ & Control & CLA & $\mathrm{P}$ & \\
\hline C $18: 1$ t 9 & 13,35 & 11,98 & $* *$ & 14,79 & 13,55 & $* *$ & 9,80 & 10,63 & $* *$ & 2,87 \\
\hline C $18: 1 \mathrm{t} 10$ & 2,84 & 2,48 & $\neq$ & 2,77 & 2,30 & $* *$ & 1,55 & 1,62 & NS & 0,35 \\
\hline C $18: 1 \mathrm{t} 11$ & 16,09 & 14,08 & $\neq$ & 15,71 & 13,02 & $* *$ & 13,96 & 14,65 & $*$ & 2,66 \\
\hline C $18: 1$ c9 & 128,06 & 99,35 & $* *$ & 111,53 & 87,58 & $* *$ & 106,30 & 112,58 & $* *$ & 16,89 \\
\hline C $18: 1 \mathrm{c} 11$ & 5,66 & 4,66 & $* *$ & 4,97 & 4,18 & $* *$ & 3,33 & 3,55 & $* *$ & 0,90 \\
\hline C $18: 1 \mathrm{t} 12$ & 1,26 & 1,15 & $* *$ & 1,37 & 1,24 & $*$ & 1,05 & 1,1 & $ま$ & 0,17 \\
\hline C $18: 1 \mathrm{t} 13$ & 0,80 & 0,70 & $*$ & 0,81 & 0,77 & $ま$ & 0,53 & 0,58 & $* *$ & 0,14 \\
\hline C $18: 1 \mathrm{t} 16$ & 2,96 & 2,61 & $* *$ & 2,38 & 2,06 & $*$ & 1,80 & 1,92 & $\neq$ & 0,55 \\
\hline C $18: 1 \mathrm{c} 15$ & 0,63 & 0,50 & $* *$ & 0,64 & 0,54 & $* *$ & 0,41 & 0,42 & $* *$ & 0,10 \\
\hline
\end{tabular}

${ }^{\top}$ Período de tratamento 1, leite coletado do $42^{\circ}$ ao $47^{\circ}$ dia da lactação; Período de Tramento 2 , leite coletado do dia $70^{\circ}$ ao $74^{\circ}$ dia da lactação

${ }^{2} \mathrm{P}<0,05=*, \mathrm{P}<0,01=* *, \mathrm{P}<0,10=\ddagger$

Podemos inferir a atividade da delta-9-dessaturase através da relação entre os produtos insaturados e seus precursores saturados, como na Tabela 26.

Observar-se que, exceto para C16:1, no período de coleta 2, as diferenças não são significativas. Como comentado acima, isso pode estar ligado ao fato destas enzimas já estarem sendo reprimidas pelos ácidos graxos presentes no óleo da farinha de peixe nas condições do rúmen destes animais sob pastejo. De qualquer forma, os resultados são contraditórios com os observados em outros trabalhos (Chouinard et al., 1998; Baumgard et al, 2000; Loor \& Herbein, 1998). 
Tabela 26. Relação entre ácidos graxos saturados e insaturados de vacas recebendo Megalac (Controle) ou CLA-60 (CLA) do $28^{\circ}$ aos $84^{\circ}$ dia em lactação(Período de Tratamento) e do $85^{\circ}$ ao $112^{\circ}$ dias em lactação (Período Residual).

Ácidos Graxos Período de Tratamento $1^{1} \begin{array}{cc}\text { Período de Tratamento } & 2^{1} \\ \text { Período Residual }\end{array}$

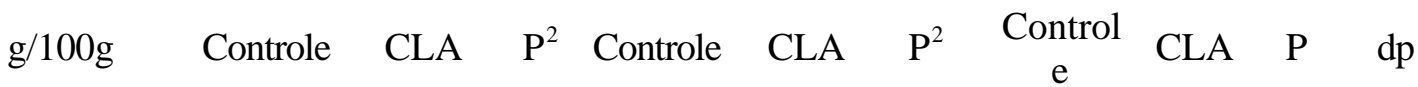

\begin{tabular}{lcccccccccc}
\hline C14:1 / C 14:0 & 9,1 & 9,3 & NS & 9,3 & 9,0 & NS & 7,6 & 7,2 & NS & 1,66 \\
C16:1 / C 16:0 & 19,3 & 18,0 & NS & 21,9 & 18,3 & $*$ & 19,1 & 17,4 & NS & 3,41 \\
C18:1 / C 18:0 & 0,38 & 0,38 & NS & 0,50 & 0,48 & NS & 0,44 & 0,41 & NS & 0,06 \\
\hline
\end{tabular}

${ }^{\mathrm{T}}$ Período de tratamento 1, leite coletado do dia 42-47; Período de Tramento 2, leite coletado do dia 70-74.

${ }^{2} \mathrm{P}<0,05=*, \mathrm{P}<0,01=* *, \mathrm{P}<0,10=\ddagger$ $\mathrm{t} 10, \mathrm{c} 12$

Na figura 7 é apresentada a regressão dos teores de gordura do leite e o isômero

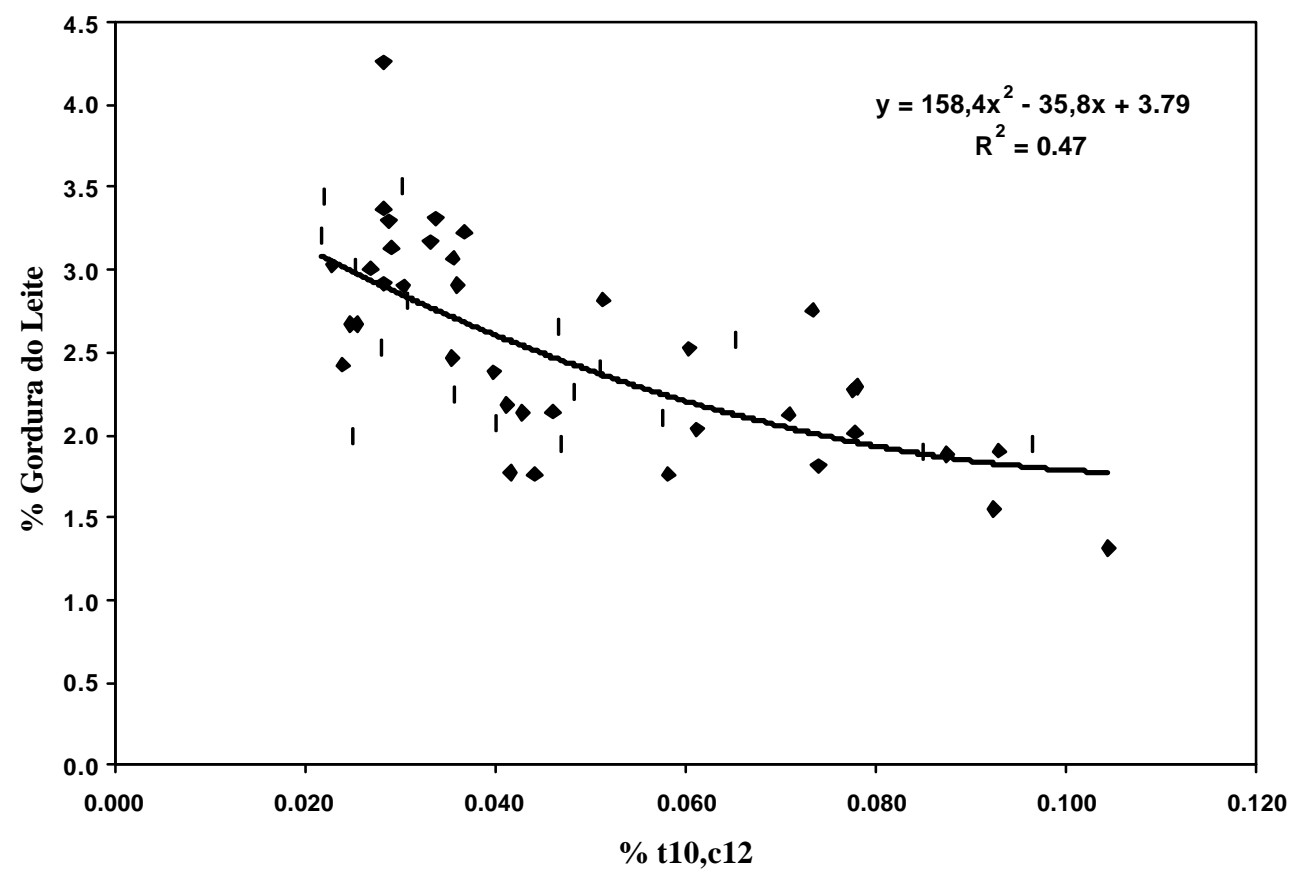

Figura 7 - Regressão dos teores de gordura do leite e o isômero t10,c12 com os dados das vacas do tratamento (CLA) e do controle (MEGALAC) 
A regressão mostra que, com o aumento do isômero, temos uma redução da gordura do leite dos animais. Dados semelhantes são apresentados por Bauman \& Griinari (2001) e por Gama et al (no prelo). Não há grande melhora no R quadrado quando selecionamos apenas as vacas tratadas ou as vacas do controle.

\subsubsection{Valores de nitrogênio uréico do leite (MUN)}

Os teores de Nitrogênio Uréico do Leite (MUN) encontrados não demosntraram ter havido diferenças significativas entre os tratamentos (Tabela 27). A falta de efeito do CLA sugere que apesar da maior secreação diária de proteína, não houve redução do teor circulante de uréia, o que seria esperado. A razão para esta falta de efeito pode ser explicada pelo teor bastante elevado de MUN. Estas altas concentrações de uréia seriam esperadas em função do elevado teor de proteína utilizado nas dietas. A concentração média encontrada, está proxima do valor conseiderado crítico para efeitos negativos na reprodução (Butler, 1996). 
Tabela 27. Teores de nitrogênio uréico do leite $(\mathrm{mg} / 100 \mathrm{ml})$ de animais recebendo Megalac (Controle) e ou CLA-60 (CLA) dos 28 aos 84 dias em lactação e do Período Residual (85-112 dias em lactação) quando receberam a mesma dieta

\begin{tabular}{|c|c|c|c|c|}
\hline & \multicolumn{2}{|c|}{ Controle } & \multicolumn{2}{|c|}{ CLA } \\
\hline & Média & $\mathrm{Dp}$ & Média & $\mathrm{dp}$ \\
\hline \multirow{3}{*}{$\begin{array}{l}\text { Nitrogênio Uréico } \\
\text { do Leite }\end{array}$} & \multicolumn{4}{|c|}{ Período de Tratamento $(\mathrm{mg} / 100 \mathrm{ml})$} \\
\hline & 19,3 & 0,6 & 19,7 & 0,6 \\
\hline & \multicolumn{4}{|c|}{ Período Residual (mg/100ml) } \\
\hline $\begin{array}{l}\text { Nitrogênio Uréico } \\
\text { do Leite }\end{array}$ & 17,3 & 0,7 & 18,3 & 0,8 \\
\hline
\end{tabular}

Os valores de porcentagem de proteína total do leite em amostras do dia posterior ao da coleta de leite para MUN, foram de 3,10\% para ruminantes tratados com CLA, E 2,82\% para controle, resultam em médias, para os animais tratados com CLA, de $3.10 \%$ e $2.82 \%$ para os animais Controle. Este resultado evidencia que o aumento da porcentagem de proteína no leite deva ser devido à síntese de proteína verdadeira foi resultado de um incremento de síntese de proteína verdadeira e não da transferência do excesso de nitrogênio uréico do sangue para o leite, o que aumentaria a proteína total, mas por aumento de nitrogênio não protéico. Novos estudos devem estabelecer qual a fração protéica estaria sendo alterada e qual o mecanismo de síntese de proteína está sendo alterada ne glândula mamária.

\subsubsection{Variáveis plasmáticas}

Na Tabela 28 estão todos os efeitos da suplementação com CLA nos períodos de tratamento e residual. São apresentados dados de ácidos graxos não esterificados (AGNE), triglicerídeos (TGA), colesterol Total (Col) e glucose (GLU). 
Tabela 28. Teores de variáveis plasmáticas de vacas recebendo Megalac (Controle) e ou CLA-60 (CLA) do $28^{\circ}$ aos $84^{\circ}$ dias em lactação e do Período Residual (85112 dias em lactação) quando receberam a mesma dieta.

\begin{tabular}{|c|c|c|c|c|}
\hline & \multicolumn{2}{|c|}{ Controle } & \multicolumn{2}{|c|}{ CLA } \\
\hline & Média & $\mathrm{dp}$ & Média & $\mathrm{dp}$ \\
\hline & \multicolumn{4}{|c|}{ Período de Tratamento } \\
\hline $\operatorname{AGNE}^{1}(\mu$ moles/litro $)$ & 224 & 19 & 148 & 20 \\
\hline Triglicerídeos (mg/100ml) & 23,9 & 1,2 & 21,9 & 1,2 \\
\hline Colesterol (mg/100ml) & 103 & 5 & 110 & 4 \\
\hline \multirow[t]{2}{*}{ Glucose $(\mathrm{mg} / 100 \mathrm{ml})$} & 50,5 & 1,3 & 48,5 & 1,2 \\
\hline & \multicolumn{4}{|c|}{ Período Residual } \\
\hline $\operatorname{AGNE}^{1}(\mu$ moles/litro $)$ & 176 & 10 & 132 & 8 \\
\hline TGA (mg/100ml) & 27,5 & 1,15 & 19,2 & 0,6 \\
\hline $\mathrm{COL}(\mathrm{mg} / 100 \mathrm{ml})$ & 116 & 7 & 120 & 5 \\
\hline GLU(mg/100ml) & 54,6 & 0,8 & 52,0 & 0,9 \\
\hline
\end{tabular}

No período de tratamento, os valores de AGNE tenderam a ser mais elevados para os animais Controle $(\mathrm{P}=0,099)$ o que sugere uma menor mobilização de gordura neste tratamento, apesar da maior produção de gordura. Uma maior mobilização poderia resultar em alteração do perfil de ácidos graxos do leite, mas a falta de diferenças na condição corporal sugerem que a magnitude da mobilização tenha sido muito pequena. No período residual, apesar dos animais Controle permanecerem com valores maiores, a diferença foi menor. As médias de AGNE (micromoles/litro) foram mais baixas ou iguais aos valores normalmente encontrados em animais de alta produção (Garcia-Bojail et al., 1998; Knowlton et al., 1998; Putnan \& Varga, 1998). Entretanto, esses valores são próximos dos obtidos por Sutton et al. (1998) com vacas de produção semelhanes às do presente experimento.

Não foram observadas diferenças durante o período de tratamento para os teores de triglicerídeos (TGA) (23 e $21 \mathrm{mg} / \mathrm{dl}$ de leite para Controle e CLA respectivamente). Contudo, durante o período residual as médias foram diferentes $(23$ e $16 \mathrm{mg} / \mathrm{dl}$ para Controle e CLA respectivamente, $\mathrm{P}<0.05)$. Os valores de concentração de colesterol apresentam variações pequenas e estão próximos aos apresentados por Bitman et al. 
(1998). As médias entre os tratamentos são muito próximas, denotando não ter havido qualquer efeito do CLA nos níveis plasmáticos do colesterol total. Resultados semelhantes foram obtidos por Lee et al. (1994), com coelhos, e Amelsvoort et al. (1997), em hamsters, que todavia encontraram alteração desejável na relação do perfil de lipoproteínas.

No caso da glucose (GLU), as concentrações dos animais Controle e CLA são muito semelhantes, em ambos os períodos, não tendo sido observado efeito da suplementação do CLA, apesar de tendência do CLA reduzir a GLU no período residual

Um aspecto que chama a atenção é que os animais que receberam CLA apresentam, no período residual, produção mais elevada de leite e de gordura, mas não há diferenças significativas para as variáveis ligadas a secreção de gordura . Os animais

que receberam CLA também apresentaram maior secreção de energia e tenderam a produzir mais lactose que os animais controle, mas houve tendência a menor concentração plasmática de GLU.

\subsubsection{Contagem de Células Somáticas}

A contagem de células somáticas (CCS, Tabela 29) transformadas para escore linear (EL) não foram afetadas pelo tratamento. O ambiente era bastante desafiador, com médias elevadas em função de alguns animais que apresentaram infecções sub-clínicas. A variação observada foi muito elevada. Ainda sim, houve uma tendência para maiores valores de EL para as vacas do grupo do CLA no período residual. 
Tabela 29. Logarítmo do número de células somáticas (CCS) em de animais recebendo Megalac (Controle) ou sais de cálcio de CLA-60 (CLA) do $28^{\circ}$ aos $84^{\circ}$ dia em lactação (Período de Tratamento) e entre o $85^{\circ}$ e o $112^{\circ}$ dias sem mais a suplementação de gordura (Período Residual)

\begin{tabular}{|c|c|c|c|c|c|}
\hline & \multicolumn{2}{|l|}{ Controle } & \multicolumn{2}{|l|}{ CLA } & \multirow[b]{2}{*}{$\mathrm{P}$} \\
\hline & Média & $\mathrm{Dp}$ & Média & $\mathrm{dp}$ & \\
\hline & \multicolumn{5}{|c|}{ Período Tratamento } \\
\hline CCS, log & 5,184 & 0,115 & 5,324 & 0,134 & \\
\hline \multirow[t]{2}{*}{ Escore Linear } & 3.9 & 0.2 & 4.2 & 0.15 & NS \\
\hline & \multicolumn{5}{|c|}{ Período Residual } \\
\hline CCS, log & 5,408 & 0,165 & 6,216 & 0,118 & \\
\hline Escore Linear & 4.1 & 0.2 & 5.3 & 0.15 & $\mathrm{P}<0.10$ \\
\hline
\end{tabular}




\section{CONCLUSÕES}

Dos alimentos analisados, a principal fonte de CLA é o leite bovino, seguido da carne bovina. Animais monogástricos contribuem muito pouco para a ingestão de CLA pelo consumidor. Há grande variação nos teores de CLA em função do sistema de produção, particularmente para o leite. Ambiente, dieta e tipo genético afetam o teor de CLA O ácido rumênico $(\mathrm{c} 9, \mathrm{t} 11)$ é o isômero preponderante em todas as situações avaliadas. Devido a grande variação no teor de CLA nos alimentos e escolhas alimentares, o consumo de CLA é bastante variável tanto no tempo, como individualmente.

Embora não exista recomendação estabelecida para ingestão diária de CLA que proteja o consumidor contra o câncer, os resultados do presente trabalho sugerem que para atingir o consumo proposto de $350 \mathrm{mg} / \mathrm{dia}$, seria necessário o enriquecimento da dieta com CLA.

A suplementação de vacas com CLA aumentou a produção de leite em uma ambiente onde o aporte de energia é limitado. Nesta condição há um aumento no teor de proteína e redução no teor de gordura . Essa alteração na composição do leite reduz a energia excretada por unidade de leite e, permite maior volume e maior quantidade de proteína para uma mesma quantidade de energia disponível 


\section{REFERÊNCIAS BIBLIOGRÁFICAS}

AKERLIND, M.; HOLTENIUS, K.; BERTILSSON, J.; EMANUELSON, M. Milk composition and feed intake in dairy cows selected for high or low milk fat percentage. Livestock Production Science, v. 59, p. 1-11, 1999.

AMELSVOORT, J.M.M.; MEIJER, G.W. The effects of conjugated linoleic acid in dietary triglycerides on atherosclerotic risk factors in the hamster. In: INTERNATIONAL SYMPOSIUM ON ATHEROSCLEROSIS, 11, Paris, 1997. Paris: FASEB, 1997 11, p. 335.

ASSOCIATION OF OFFICIAL ANALYTICAL CHEMISTS. Official methods of anaylsis.16 ed. Arlington, 1995. 1298 p.

ASTRUP, H.N., VIK-MO, L., EKERN, A. E BAKKE, F. Feeding protected and unprotected oils to dairy cows. Journal of Dairy Science, v. 59, p. 426-430, 1976.

BANNI, S.; CARTA, G.; ANGIONE, E.; MURRU. E.; SCANU, P.; MELIS, M.P.; BAUMAN, D.E.; FISHER, S.M.; IP, C. Distribution of conjugated linoleic acid and metabolites in different lipid fractions in the rat liver. Journal of Lipid Research. v.42, p.1056-1061, 2001.

BAUCHART D, VERITE R, REMOND B. Long fatty acid digestion in lactating cows fed fresh grass from spring to autumn. Canadian Journal of Aninal Science. v. 64, p.330-331, 1984, supplement 1.

BAUMAN, D.E.; GRIINARI, J.M. Regulation and nutrtional manipulation of milk fat: low-fat milk syndrome. Livestock Production Science. v. 70, p. 15-29, 2001.

BAUMAN, D.E.; Conjugated linoleic acid and milk fat synthesis in dairy cows. In: INTERNATIONAL CONFERENCE ON CLA, 1, Alesund, 2001. Proceedings. Alesund: NATURAL ASA, 2001 , p.24. 
BAUMGARD, L.H.; CORL, B.L.; DWYER, D. A.; SAEBO, A.; BAUMAN, D.E. Identification of the conjugated linoleic acid isomer that inhibits milk fat synthesis. American Journal Physiology,. v. 278, p. 179-184, 2000.

BARBER, M.C.; CLEGG, R.A; TRAVERS, M.T.; VERNON, R.G. Lipid metabolism in the lactating mammary gland. Biochimica et Biophysica Acta. v. 1347, p. 101-126, 1997.

BEALIEU, E.; DRACKLEY. Milk and meat samples obtained in Illinois contain variable amounts of CLA. Journal of Animal Science. v. 79, p. 310, 2001, Supplement 1.

BEAM, T.M.; JENKINS, T.C.; MOATE, P.J.; KOHN, R.A.; PALMQUIST, D.L. Effects of amount and source of fat on the rate os lipolysis and biohydrogenation of fatty acids in rumnal contents. Journal of Dairy Science. v. 81 p.2540-2559, 2000.

BEQUETTE, B.J.; BACKWELL, F.R.C.; CROMPTOM, L.A. Current concepts of amino acid metabolism in the mammary gland of the lactating ruminant. Journal of Dairy Science, v. 81, p. 2540-2559, 1998.

BITMAN, J; WOOD, D.L.; LEFCORT, A.M. Rhythms in cholesterol, cholestoryl esters, free fat acids and Tryglicerides in blood of lactating dairy cows. et al. Journal of Dairy Science, v. 73, p. 948-955, 1990.

BOGNOUX, P.; LAVILLONNIERE, F.; GARAUD, P.; JOURDAN, M.L.; SEBEDIO, J.L.; CHAJES, V. CLA in experimental mammary tumors and in breast cancer. In: INTERNATIONAL CONFERENCE ON CLA, 1, Alesund, 2001. Proceedings. Alesund: NATURAL ASA, 2001 , p. 9.

BULLE, M.L.M. Desempenho, composição corporal e exigências líquidas de energia e proteína de tourinhos de dois tipos genéticos alimentados com dietas de alto teor de concentrado. Piracicaba, 2000. 51p. Dissertação (Mestrado) Escola Superior de Agricultura "Luiz de Queiroz", Universidade de São Paulo.

BUTLER, W.R.; CALAMAN, J.J.; BEAM, S.W. Plasma and milk urea nitrogen in relation to pregnancy rate in lactating dairy cattle. Journal of Animal Science. v.79, p.858-865, 1996.

BUTLER, W.R. Nutritional interactions with reproductive performance in dairy cattle. Animal Production Science, v.60/61, p. 449-457, 2000.

CHIN, S.F.; LIU, W.; STORKSON, J.M.; HA, Y.L.; PARIZA, M.W. Dietary sources of conjugated dienoic isomers of linoleic acid, a newly recognized class of anticarcinogens. Journal of Food Composition and Analysis. v.5, p.185-197, 1992. 
CHOUIRNAD, P.Y.; CORNEAU, L.; SAEBO, A.; BAUMAN, D.E. Milk yield and composition during abomasal infusion of CLA in dairy cows. Journal of Dairy Science , v.82 p.2737-2745, 1998.

CHOUIRNAD, P.Y.; BAUMAN, D.E.; CORL, B.A.; BAUMGARD, L.H.; McGUIRE, M.A.; GIESY, J.G. An update on conjugated linoleic acid. In: CORNELL NUTRITION CONFERENCE, Ithaca, 2000. Proceedings. Ithaca: CORNELL UNIVERSITY, 2000, p. 93-101.

CHOUINARD, P. Y.; BAUMAN, B. A.; BAUMGARD, M.A. An update an conjugated linoleic acid. In: CORNELL NUTRITIONAL CONFERENCE FEED MANUFACTORY, 1., Ithaca, 1999. Proccedings. Ithaca: CORNELL UNIVERSITY, 1999, p. 93-101.

CHOUIRNAD, P.Y.; CORNEAU, L.; BUTLER, W.R.; CHILlIARD, Y.; DRACKLEY, J.K.; BAUMAN, D.E. Effect of dietary lipid source on conjugated linoleic acid concentration on milk fat. Journal of Dairy Science, v.84, p.680-690, 2001.

CHILlIARD, Y.; FERLAY, A.; MANSBRIDGE, M.; DOREAU, M. Ruminant milk fat plasticity: Nutritional control of saturated, polyunsaturated, trans and conjugated fatty acids. Annales Zootechnie. v. 49, p. 181-205, 2000.

CHILLIARD, Y.; FERLAY, A.; DOREAU, M. Effects of different types of forages, animal fat or marine oils in cows diets on milk fat secretion and composition, especially conjugated: Nutritional control of saturated, polyunsaturated, trans and conjugated linoleic acids (CLA) and polyunsaturated fatty acids. Livestock Production Science v. 70, p. 31-48, 2001.

CHIN, S.F.; LIU, W.; STORKSON, M.; HA, Y.L.; PARIZA, M. W. Dietary sources of conjugated dienoic isomers of linoleic acid, a newly recognized class of anticarcinogens. Journal of Food Composition and Analysis, v. 5, p. 185-197, 1992.

CHRISTIE, W.W. A simple procedure for rapid transmethylation of glycerolipids e cholesterol esters. Journal of Lipid Research. v. 23, p. 1072, 1982

CHRISTIE, W.W. The effects of diet and other factor on the lipid composition fo ruminant tissue and milk. In: W.W. CHRISTIE (Ed.) Lipid Metabolism in Ruminant Animals. Oxford: Pergamon Press, 1981, cap.5, p. 225-275. 
COOK, M.E.; MILLER, C.C.; PARK, Y.; PARIZA, M. Immune modulation by altered nutrient metabolism: nutritional control of immune-induced growth depression. Poultry Science, v.72, p.1301-1305, 1993.

COOK, M.E., L.D. WHIGHAM; M. YANG; M.W. PARIZA. CLA inhibitis the induction of prostaglandin and leukotriene synthesis. A natural substitute for non-steroidal andti-inflammatory drugs ? In: INTERNATIONAL CONFERENCE ON CLA, 1. Alesund, 2001. Proceedings. Alesund: NATURAL ASA, 2001, p. 6-7.

CORL, B.A.; BAUMGARD, L.H.; DWYER, D.A.; GRIINARI, J.M.; PHILIPS; B.S.; BAUMAN, D.E. The role of delta-9-desaturase in the production of cis-9, trans-11 CLA and other delta-9 desaturated fatty acids in milk fat. Journal of Dairy Science. v. 83 , p.164, 2000, supllement 1 .

CRESPO, N; ESTEVE-GARCIA. Dietary fatty acid profile modifies abdominal fat deposition in broiler chickens. Poultry Science. v.80, p.71-78, 2001.

CRUZ, G.M.; TULLIO, R.R.; ALLEONI, G.F.; CORDEIRO. C.A.; BERNDT, A.; ALENCAR, M.M.; LANNA, D.P.D. Desempenho e caracteristicas das carcaças de machos não-castrados de diferentes grupos genéticos em confinamento em relação ao status nutricional na fase de pastejo. In: REUNIÃO DA SBZ, 37, Anais Viçosa: SBZ, 2000, p. 54-55.

DAVIS, C.L.; BROWN, R.E. Low fat milk sindrome. In: PHILLIPSON, A.T. (ed.) Digestion and metabolism in ruminants. Newcastle upon Tyne: Oriel Press, 1970, 545p.

DeLANY, J.P.; WEST, D.B. Changes in body composition with conjugated linoleic acid. Journal of the American College of Nutrition. v. 19, p. 487S-493S, 2000.

DE SMET et al. Effect of dietary energy and protein levels on fatty acid composition of intramuscular fat in double-muscled belgian blue bulls. Meat Science v. 56, p. 73-79, 2000.

De PETERS, E.J.; MEDRANO, J. F.; REED, B.A. Fatty acid compisition of milk fat from three breeds of dairy cattle. Canadian Journal of Animal Science, v. 75, p. 267-269, 1995.

DEMEYER, D.; DOREAU, M. Targets and procedures for altering ruminant meat and milk lipids. Proccedings of the Nutrition Society. v.58, p.593-607, 1999. 
DHIMAN, T.T.; ANAND, G.R.; SATTER, L.D.; PARIZA, M.W. Conjugated linoleic acid content of milk from cows fed different diets. Journal of Dairy Science, v. 82, p. 2146-2156, 2000.

DHIMAN, T.R.; OLSO, K.C.; MACQUEEN, I.S.; PARIZA, M.W. Conjugated linoleic acid content of meat from steers fed soybean oil. Journal of Dairy Science, v.82, p.84, 1999, supplement 1.

DONOVAN, D.C.; SCHINGOETHE, D.J.; BAER, R.J.; HIPPEN, A.R.; FRANKLIN, S.T. Influence of dietary fish oil on conjugated linoleic acid and other fatty acids in milk fat from lactating dairy cows. Journal of Dairy Science, v.83, p.2620-2628, 2000.

DU, M.; NAM, K.C.; HUR, S.J.; ISMAIL, H.; AHN, D.U. Efeect of dietary conjugated linoleic acid, irradiation, and packaging conditions on the quality characteristics of raw broiler breast fillets. Meat Science, v.60, p.9-15, 2002.

DUCKETT, S.K.; ANDRAE, J. G. Inffluences of nutrition and management practices on intramuscular fat deposition and fatty acid profiles in beef. In: PLAINS NUTRITION COUNCIL SPRING CONFERENCE, PUBLICATION NO. AREC 00-22, Texas, 2000. Proceedings . Amarillo: A\&M Research and Extension Center, 2000 p. 13-24.

DUCKETT, S.K.; WAGNER, D.G.; YATES, L.D.; DOLEZAL, H.G.; MAY, S.G. Effects of time on feed on beef nutrient composition. Journal of Animal Science. v.71, p.2079-2088, 1993.

DUNSHEA, T.R., OSTROWSKA, E.; MURILITARAM, M.; CROSS, R, BAUMAN, D.E, PARIZA, M.W.; SKARIE, C. Dietary conjugated linoleic acid decrease back fat in finisher gilts. Journal Animal Scence. v. 76, 1998, supplement 1.

EDWARDS, H.M. Factors influencing body composition of broilers. In: ARKANSAS NUTRITION CONFERENCE, Conway, 1980 Proceedings. Conway: ARKANSAS UNIVERSITY, 1980, p. 17-28.

ENSER, M.; HALLETT, K.; HEWETT, B; FURSEY, G.A.J.; WOOD, J.D. Fatty acid content and composition of english beef, lamb and pork at retail. Meat Science, v. 42, p. 443-456, 1996.

ENSER, M; HALLETE, K.; HEWETT, B.; FURSEY, G.A.J.; WOOD, J.D.; HARRINGTON, G. Fatty acid content and composition of UK beef and lamb muscle in relation to production system and implications for human nutrition. Meat Science, v. 49, p. 329-341, 1998. 
ENJALBERT, F.; NICOT, M. C.; BAYYOURTHE, C.; MONCOULON, R. Duodenal infusions of palmitic, stearic or oleic acids differenthy affect mammary gland metabolism of fatty acids in lactating dairy cows. Journal of Nutrition, v. 128, p. 1525-1532, 1998.

FELLNER, V.; SAUER, F.D.; KRAMER, J.K.G.; Steady-State rates of linoleic acid biohydrogenation by ruminal bacteria in continuos culture. Journal Dairy Science, v. 78, p. 1815-1823, 1995.

FERLAY, A.; CHABROT, J.; ELMEDDAH, Y.; DOREAU, M. Ruminal lipid balance and intestinal digestion by dairy cows fed calcium salts of rapeseed oil fatty acids or rapeseed oil. Journal of Animal Science, v. 71, p. 2237-2245, 1993.

GARCIA-BOJALIL, C.M.; STAPLES, RISCO, C.A.; SAVIO,J.D.; THATCHER, W.W. Protein degradability and calcium salts of long chain fatty acids in diets of lactating cows: productive responses. Journal of Dairy Science, v. 81, p. 1374-1384, 1998.

GAYNOR, P.J.; ERDMAN, E.R.L TETER, B.B., SAPUGNA, J.; et al. Milk fat yield and composition during abomasal infusion of cis or trans octadeceonatos in Holstein cows. Journal of Dairy Science v. 81, p. 1374-1384, 1994.

GIESY, J.G.; HNASON; L.R.; M. ROBINSON; H.C. HAFLIGER; S. VISWANADHA; M.A. MCGUIRE, C.H. SKARIE; A. VINCI. Effects of calcium salts of CLA on milk yield, fat and CLA content of milk fat in Holstein cows early in lactation. Journal of Dairy Science, v. 82, p. 83-84, 1999a, supplement 1 .

GIESY, J.G.; S. VISWANADHA; T.W. HNASON; L.R. FALEN; M.A. MCGUIRE, C.H. SKARIE; A. VINCI. Effects of calcium salts of CLA on estimated energy balance in Holstein cows early in lactation. Journal of Dairy Science, v. 82, p.74, 1999b, supplement 1.

GRIINARI, J. M., MCGUIRE, DWYER, D. A., M. A., BAUMAN, D. E.; PALMQUIST, D. L. Role of insulin in the regulation of milk fat synthesis in dairy cows. Journal of Dairy Science, v. 80, p. 1076-1084, 1997a..

GRIINARI, J.M., P.Y. CHOUINARD, AND D.E. BAUMAN. Trans fatty acid hipothesis of milk fat depression revised. In: CORNELL NUTRITION CONFERENCE, 59, Ithaca, 1997b. Proceedings. Ithaca: CORNELL UNIVERSITY, 1997b, p. 208-216. 
GRIINARI, J. M.; DWYER, D. A.; MCGUIRE, M. A.; BAUMAN, D. E.; PALMQUIST, D. L.; NURMELA, K.V.V. Trans-octadecenoic acids and milk fat depression in lactating dairy cows. Journal of Dairy Science, v. 81, p. 1251-1261, 1998.

HA, Y.L.; GRIMM, N.K.; PARIZA, M.W. Anticarcinogens from fried ground beef: heat-altered derivatives of linoleic acid. Carcinogenesis, v.8, p.1881-1887, 1987.

HANSEN, H.O.; KNUDSEN, J. Effects of exogenous long-chain fatty acids on lipi salts of CLA on estimated energy balance in Holstein cows early in lactation. Journal of Dairy Science v. 70 p.1344, 1987.

HARA, A.; RADIN, N.S. Lipid extraction of tissues with low-toxicity solvent. Analytical Biochemistry, v. 90, p. 420-426, 1978.

HARFOOT, C.G.; HAZELWOOD, G.P. Lipid metabolism in the rumen. In: P.N, HOBSON (Ed.), The rumen microbial ecossystem., Elsevier, 1988. 527p.

HORNICK, J.L.; VAN EENAEME, C.; CLIMQUART, A.; DIEZ, M.; ISTASSE, L. Different periods of feed restriction before compensatory growth in belgian blue bulls: I. Animal performance, nitrogen balance, meat characteristics, and fat composition. Journal of Animal Science. v.76, p.249-259, 1998.

HUANG, Y.; BRADFORD, B.; HEIG, N.; YOUNG, J.; BEITZ, D. Feeding Dairy Cattle to Increase the Content of Conjugated Linoleic Acid in Milk. Journal of Animal Science. v. 79, p. 310, 2001. supplement 1.

HUERTA-LEIDENZ, N.O.; CROSS, H.R.; SAVELL, J.W.; LUNT, D.K.; BACKER, J.F.; PELTON, L.S.; SMITH, S.B. Comparison of the fatty acid composition of subcutaneous adipose tissue from mature Brahman and Hereford cows. Journal of Animal Science. v.71, p.625-630, 1993.

HUERTA-LEIDENZ, N.O.; CROSS, H.R.; SAVELL, J.W.; LUNT, D.K.; BACKER, J.F.; SMITH, S.B. Fatty acid composition of subcutaneous adipose tissue from male calves at different stages of growth. Journal of Animal Science. v.74, p.1256-1264, 1996.

INGLE DL, JOHNSON DE, BAUMAN DE, MELLENBE.RW, Lipogenesis and lipolysis of sheep adipose-tissue during fatting. Journal of Animal Science, v. 74, p. 203, 1972.

IP, C. CLA and cancer prevention. In: INTERNATIONAL CONFERENCE ON CLA, 1. Alesund, 2001. Proceedings. Alesund: NATURAL ASA, 2001, p. 6-7. 
IP, C; CHIN, S.F.; SCIMECA, J.A. E PARIZA, M.W.. Mammary cancer prevention by conjugated dienoic derivative of linoleic acid. Cancer Research v. 51 p. 6118-6124, 1991.

IP, C; THOMPSON, M.; SINGH, M. E SCIMECA,J.A.. Conjugated linoleic acid suppresses mammary carcinogenesis and proliferative activity of the mammary gland in the rat. Cancer Research, v. 54 p. 1212-1215, 1994.

IP, M.M.; P.A. MASSO-WELCH, C. IP, D. ZANGANI; P. LEE. Inhibition of angiogenesis by CLA. In: INTERNATIONAL CONFERENCE ON CLA, 1. Alesund, 2001. Proceedings. Alesund: NATURAL ASA, 2001, p. 9.

JAHREIS, G.; J. FRITSHE; S. C. HANS S. Conjugated linoleic acid in milk fat: high variation depending on the production system. Nutrition Research, v. 17, p.1479-1484, 1997.

JAHREIS, G.; J. FRITSHE; S. C. HANS STEINHART. Conjugated linoleic acid in milk fat: high variation depending on the production system. Nutrition Research, v. 17, p.1479-1484, 1997.

JENKINS, T.C.; BATEMAN, H.G.; BLOCK, S.M. Butylsoyamide increases unsaturation of fatty acids in plasma and milk of lactating dairy cows. Journal of Dairy Science, v. 79, p. 438-445, 1996.

JIANG, J; L. BJOERCK; R. FONDÉN; M. EMANUELASON.Occurrence of conjugated Cis -9, Trans-11Octadecadienoic acid in bovine milk: Effect of Feed and Dietary Regimen. Journal of Dairy Science v. 79, p. 438-445. 1996.

KENNELLY, J.J. Producing milk with 2,5\% fat- The biology and health implications for dairy cows. Animal Feed Science Technology. v. 60, p. 161-180, 1996.

KAULSCHER, K.F.; TETER B.B.; PIPEROVA, L.S.; ERDMAN, R.A. Effect of dietary forage concetration and buffer addition on duodenal flow of trans- $\mathrm{C}_{18: 1}$ fatty acids and milk fat production in dairy cows. Journal of Dairy Science v. 80, p. 2104-2114, 1997.

KELLY, M.L.; KOLVER, E.S.; BAUMAN, D.E.; VAN AMBURGH, M.E.; MULLER, L.D. Effect of intake of pasture on concentrations of conjugated linoleic acid in milk of lactating cows. Journal of Dairy Science v. 81, p. 1630-1636, 1998.

KELSEY, J.A.; PETERSON, D.G.; BAUMAN, D.E. Analysis of the sources of variation in cla production in dairy cows. Journal of Dairy Science v. 84, p. 313, 2001. 
KIM, J.Y.; LIU, R.H.; BOND, D.R.; RUSSELL, J.B. Effect of linoleic acid concentration on conjugated linoleic acid production by Butyrivibrio fibrisolvens A38. Applied and Environmental Microbiology v. 66, p. 5226-5230, 2000.

KINSELLA, J.E. Stearyl CoA as a precursor of oleic acid and glycerolipids in mammary microsomes from lactating bovine: possible regulatory step in milk triglyceride synthesis. Lipids v. 7, p. 349-355, 1972.

KNEKT, P.R.; JARVINEN, R.; SEPPANEN, R.; PUKKALA, E.; AROMAA, A. Intake of dairy products and the risk of breast cancer. Journal of Cancer v. 73, p. 687691, 1996

KNOWLTON, K.F., DAVSON, T.E.; GLENN, P.B.; HUNTINGTON, G.B.; ERDMAN, R.A. Glucose metabolism and milk yield of cows infused abomasally or ruminally with starch. Journal of Dairy Science v. 73, p. 1784-1787, 1998.

KRAMER, J.K.G.; FELLNER, V.; DUGAN, M.E.R.; SAUNER, F.D.; MOSSOBA, M.M.; YURAWECZ, M.P. Evaluating acid and base catalysts in the methylation of milk and rumen fatty acids with special emphasis on conjugated dienes and total trans fatty acids. Lipids . v.32, p. 1219-1228, 1997.

KENNELY, J.J; D.R. GLIMM; L. OZIMEK. Milk composition in the cow. In: CORNELL NUTRITION CONFERENCE, 61. Ithaca, 1999. Proceedings. Ithaca: CORNELL UNIVERSITY, 1999, p.1-21.

LAWLESS, F.; MURPHY, J.J., HARRINGTON, D.; DEVERY, R.; STANTON, C. Elevation of CLA c9,t11-octadecadienoic acid in bovine milk because of dietary supplementation. Journal of Dairy Science • v. 81, p. 3259-3267, 1998.

LAWRENCE, T.J.L.; FOWLER, V.R.; . Tissues. In: GROWTH OF FARM ANIMALS. Londres, 1997. Londres:CAB INTERNATIONAL, 1997, 331 p.

LEDOUX, M.; ROUZEAU, A.; BAS, P.; SAUVANT, D. Occurrence of trans-C18:1 fatty acid isomers in goat milk: effect of two dietary regimens. Journal of Dairy Science . v.85, p. 190-197, 2002.

LEE, K.N.; KRITCHEVSKY, D., PARIZA, M.W. Conjugated linoleic acid and atherosclerosis in rabbits. Atherosclerosis. v. 108, p. 19-25, 1994.

LIN, H.; BOYLSTON, T.D.; LUEDECKE, L.O.; SHULTZ. Factors Affecting the conjugated linoleic acid content of cheddar cheese. American Chemical Society. v.46, p. 803-807, 1998. 
LIN, H.; BOYLSTON, T.D.; CHANG, M.J.; LUEDECKE, L.O.; SHULTZ. Survey of conjugated linoleic acid contents of dairy products. Journal of Dairy Science. v. 78, p. 2358-2365, 1995.

LOOR, J.J.; HERBEIN, J.H. Exogenous conjugated linoleic acid isomers reduce bovine milk fat concentration and yield by inhibiting de novo fatty acid synthesis. American Societ for Nutritional Sciences, v. 128, p. 2411-2419, 1998.

LOCK, A.L.; GARNSWORTHY, P.C. The effects of fresh and conserved grass diets on the conjugated linoleic acid content of cows millk. In: INTERNATIONAL CONFERENCE ON CLA, 1. Alesund, 2001. Proceedings. Alesund: NATURAL ASA 1. , 2001, p. 43

MACKLE, T.; BAUMAN, D.E. Recent developments in the regulation of milk protein production. In: CORNELL NUTRITION CONFERENCE, 60, Ithaca, 1998. Proceedings. Ithaca: CORNELL UNIVERSITY, 1998. p. 104-112.

MAIA, E.L.; RODRIGUES-AMAYA, D.B.; FRANCO, M.R.B. Fatty acids of the total, neutral, and phospholipids of the brasilian freshwater fish Prochilodus scrofa. Journal of food composition and analysis. v. 7, p.240-251, 1994.

MALAU-ADULI, A.E.O.; SIEBERT, B.D.; BOTTEMA, C.D.K.; PITCHFORD, W.S. Breed Comparison of the Fatty Acid Composition of Muscle Phospholipids in Jersey and Limousin Cattle. Journal of Animal Science. v.76, p.766-773, 1998.

MALAU-ADULI, A.E.O.; SIEBERT, B.D.; BOTTEMA, C.D.K.; PITCHFORD, W.S. A comparison of the fatty acid composition of triacylglycerols in adipose tissue from Limousin and Jersey cattle. Aust. Journal of Agricultural Research. v.48, p. 715-722, 1997.

MANDELL, I.B.; BUCHANAN-SMITH, J.G.; CAMPBELL, C.P. Effects of forage vs grain feeding on carcass characteristics, fatty acid composition, and beef quality in limousin-cross steers when time on feed is controlled. Journal of Animal Science. v.76, p.2619-2630, 1998.

MANDELL, I.B.; BUCHANAN-SMITH, J.G.; HOLUB, B.J.; CAMPBELL, C.P. Effects of fish meal in beef cattle diets in growth performance, carcass characteristics, and fitty acid composition of longissimus muscle. Journal of Animal Science. v. 75, p. 910-919, 1997; 
MARMER, W.N.; MAXWELL, R.J.; WILLIAMS, J.E. Effects of dietary regimen and tissue site on bovine fatty acid profiles. Journal of Animal Science. v.59, n.1,p.109-121, 1984.

MCGUIRE M.A., GRIINARI J.M., DWYER D.A., BAUMAN, D.E. Role of insulin in the regulation of mammary synthesis of fat and protein. Journal of Dairy Science v. 78 no. 4, p. 816-824, 1995.

MCGUIRE, M.A. MCGUIRE, M.K, MCGUIRE, M.S. E GRIINARI, J.M.. Bovinic acid: the natural CLA. In: CORNELL NUTRITION CONFERENCE, 59. Ithaca, 1997. Proceedings. Ithaca: CORNELL UNIVERSITY,1997, p.217-226.

MOHEDE, I.; ALBERS, R.; VAN DER WIELEN, R.; BRINK, L.; DOROVSKA-TARAN, V. Immunomodulaion: CLA Stimulates Antigen Specific Antibody Production in Humans. In: INTERNATIONAL CONFERENCE ON CLA, 1. Alesund, 2001. Proceedings. Alesund: NATURAL ASA, 2001, p. 12.

MOLONEY, A. P.; PRENCH, P. Fatty acid composition and eating quality of muscle from steers offered grazed grass, grass silage or concentrated-based diets. In: INTERNATIONAL GRASSLAND CONGRESS, 19. São Pedro, 2001. Proceedings. São Pedro: SBZ, 2001, p.708-709.

NETER, J.; WASERMAN, W. Topics in regression analysis. In: NETER, J.; WASERMAN, W Applied linear statistical models. Homewood: Illinois, 1974. cap.5, p. 160-169.

NRC. Nutrient Requirements of Beef Cattle, Washington, 1996. 242 p.

NRC. Nutrient Requirements of Dairy Cattle, Washington, 2001. 381p.

NURNBERG, K.; WEGNER, J.; ENDER, K. Factors influencing fat composition in muscle and adipose tissue of farm animals. Livestock Production Science. v.56, p.145-156, 1998.

O'KELLY, J.C.; REICH, H.P. The fatty acid composition of tropical pastures. Journal of Agricultural Science. v. 86, p. 427-429, 1976.

OSTROWSKA, E.; MURALITHARAN, M.; CROSS, R.F.; BAUMAN, D.E.; DUNSHEA, F.R. Dietary Conjugated Linoleic Acids Increase Lean Tissue and Decrease Fat Deposition in Growing Pigs. American Society for Nutritional Sciences, v. 129, n. 11, p. 2037-2042, 1999. 
PALMIQUIST, D.L.; GRIINARI, M. Dietary fish oil plus vegetable oil maximizes trans-18:1 and rumenic acid in milk fat. Journal of Animal Science, 79 Abstract 1283, 2001, supplemente 1.

PARIZA, M. CLA: Unravelling the isomer Paradox In: INTERNATIONAL CONFERENCE ON CLA, 1. Alesund, 2001. Proceedings. Alesund: NATURAL ASA, 2001, p. 5.

PARIZA, M. W. AND HA, Y. L.. Conjugated dienoic derivatives of linoleic acid: a new class of anticarcinogens. Medical Oncology Tumor Pharmacotherapy. v. 7 p. 169-171. 1990.

PARK, Y., ALBRIGHT, K.J., LIU, W., STORKSON, J.M., COOK, M.E E PARIZA, M.W.Effect of conjugated linoleic acid on body composition in mice. Lipids, v.32, p. 853-858, 1997.

PARK, Y; J.M. STORKSON; K.J. ALBRIGHT, W. LIU; M.W. PARIZA. Evidence that the trans-10, cis-12 isomer of conjugated linoleic acid induces body composition in mice. Lipids. v. 34 p. 235-241, 1999.

PARODI, P. W. The anticarcinogenic effects of bovine milk fat. Journal of Dairy Science v. 81, p. 236, 1998, supplement 1 .

PENINGTON, J.A.; C.L. DAVIS. Effects of intraruminal and intraabomasal additions of cod liver oil on milk fat production in the cow. Journal of Dairy Science, v. 58, p. 49-55, 1975

PETHICK,D.W.; DUNSHEA, F.R. Fat metabolism and turnover. In: FORBES, J.M.; FRANCE, J. (Eds.) Quantitative aspects of ruminant metabolism. Londres: CAB International. 1993, cap. 13 p. 292311.

POTHOVEN, M. A. D.; BEITZ, D.C., ZIMMERLI, A. Fatty acid composition of bovine adipose tissue and of in vitro lipognesis. Journal of Nutrition. v. 104 p. 430, 1974

PIPEROVA, L. S., TETER, B. B., BRUCKENTAL, I, SAMPUGNA, J., AND ERDMAN, R. A. Association of diet induced increases in milk trans fatty acids with the activities of acetyl-CoA carboxylase and fatty acid synthetase in the mammary gland of lactating dairy cows. Journal of Dairy Science v. 81, p. 352, 1998. Supplement 1.

PRESCOTT, N.J.; WOOD, J.D. The influence of dietary linoleic acid on backfat firmness in bacon weight pigs. Animal Production. v.46, p.502. (Abstract). 
PUTNAM, D.E.; VARGA, GA. Protein Density and Its Influence on Metabolite Concentration and Nitrogen Retention by Holstein Cows in Late Gestation. Journal of Dairy Science v. 81, p. 16081618, 1998.

RAMSAY, T.G.; EVOCK-CLOVER, C.M.; STEELE, N.C.; AZAIN, M.J. Dietary conjugated linoleic acid alters fatty acid composition of pig skeletal muscle and fat. Journal of Animal Science. v.79, p. 2152-2161, 2001.

RITZENTHALER, K.L.; McGUIRE, M.K.; FALEN, R.; SHULTZ, T.D.; DASGUPTA, N.; McGUIRE, M.A. etimation of conjugated acid intake by written dietary assessment methodologies underestimates actual intake evaluated by food duplicate methodology. Journal of Nutrition. v. 131, p.1548-1554, 2001.

RULE, D.C.; BUSBOOM, J.R.; KERCHER, C.J. effect of dietary canola on fatty acid composition of bovine adipose tissue, muscle, kidney, and liver. Journal of Animal Science. v. 72, p. 2735, 1995.

SALMINEN, i.'MUTANEN, M.; JAUHIAINEN, ARO, A. Dietary trans fatty acids increase conjugated linoleic acid levels in human serum. Nutritional Biochemistry, v. 9, p. 93-96, 1998.

SANTOS, L.F.; LANA, R.P.; SILVA, M.T.C.; BRANDÃO, S.C.C.; VARGAS, L.H. Effect of Lipids Supplementation in the Ration on Production of Conjugated Linoleic Acid (CLA) and Milk Fat Composition of Dairy Cows. Journal of Animal Science v. 78, p. 82, 2000.

SANZ, M.; LOPEZ-BOTE, C.J.; FLORES, A.; CARMONA, J.M. Effect of the inclusion time of dietary saturated and unsaturated fats before slaughter on the accumulation the accumulation and composition of abdominal fat in female broiler chickens. Poultry Scince. v.79, p.1320-1325, 2000.

SANZ, M.; LOPEZ-BOTE, C.J.; FLORES, A.; CARMONA, J.M; Effect of the inclusion time of dietary saturated and unsaturated fats before slaughter on the accumulation and compositation of abdominal fat in female broiler chickens. Poultry Science, v. 79, p. 1320-1325, 2001.

SAS Institute SAS/STAT ${ }^{\mathrm{TM}}$ Guide for personal computers. Cary: SAS Institute, 2000.

SEBEDIO, J.L.; GNAEDIG, S.; CHARDIGNY, J. Recent advances in conjugated linoleic acid research. Current Opinion in Clinical Nutritio and Metabolic Care, v. 2, p.499-506, 1999. 
SELNER, D. R., AND SCHULTZ, L. H. Effects of feeding oleic acid or hydrogenated vegetable oils to lactating dairy cows. Journal of Dairy Science v. 63, p.1235-1241, 1980.

SHANTA, N.C.; RAM, L.N.; O’LEARY, J.; HICKS, C.L.; DECKER, E.A. conjugated linoleic acid concentrations in dairy products as affected by processing and storage. Journal of Food Science, v. 60, p. 695-697, 1995.

SMITH, D.R.; KNABE, D.A.; SMITH, S.B. Depression of lipogenesis in swine adipose tissue by specific dietary fatty acids. Journal of Animal Science. v.74, p.975-983, 1996.

SPRINKLE et al. Adipose tissue portioning of limited-fed beef cattle and beef cattle with ad libitum access to feed differing in adaptation to heat. Journal of Animal Science v. 76, p. 665-673, 1998.

STANTON, C.; NORDGREN, M.; ROSBERG, E.; FITZGERALD, G.; DEVERY, R.; ROSS, R.P. Human Intestinal Isolates with Ability to Efficiently Synthesise CLA. In: INTERNATIONAL CONFERENCE ON CLA, 1. Alesund, 2001. Proceedings. Alesund: NATURAL ASA, 2001, p. 17.

STENE, O.; THUEN, E.; LINSTAD, P.; HUANG, A. CLA in milk from cows of two different produciton systems. In: INTERNATIONAL CONFERENCE ON CLA, 1. Alesund, 2001. Proceedings. Alesund: NATURAL ASA, 2001, p 61.

SUKHIJA, P.S.; PALMQUIST, D.L. Dissociation of camcium soaps of long -chain fatty acids in rumen fluid. Journal of Dairy Science v. 73, p. 1784-1787, 1990.

SUNDQUIST, M.; NILSSON, I.; WIDIGS, G. CLA content high in meat form cattle grazing natural grasslands. In: INTERNATIONAL CONFERENCE ON CLA, 1. Alesund, 2001. Proceedings. Alesund: NATURAL ASA, 2001, p. 62.

SUTTON, J. D. Altering milk composition by feeding. Journal of Dairy Science. v. 72: p. 2801- 2814, 1989.

SUTTON, J.D.; HART, I.C.; MORANT, S.V.; SCHULLER, E.S.; SIMMONDS, A.D. Feeding Frequency for Lactating Cows: Diurnal Patterns of Hormones and Metabolites in Peripheral Blood in Relation to Milk-Fat Concentration. British Journal of Nutrition.v. 60, p. 265-274, 1998. 
SWATLAND, H.J. Near-infrared birefringence and transmittance of pork in relation to ph, sarcomere length, cold-shortening, and causes of paleness. Food Resarch Internatiol. v. 28, p. 153-159, 1995.

THIEL- COOPER, R.L.; PARRISH Jr, F.C.; SPARKS, J.C.; WIEGAND, B.R.; EW AN, R.C. Conjugated linoleic acid changes swine performance and carcass composition. Journal Animal Science. v.79, p.1821-1828, 2001.

VAN SOEST, P. J. Nutritional ecology of the ruminant. 2. ed. Ithaca: CORNELL UNIVERSITY, 1994, 476p.

WEBB, E.C.; ET AL. Effect of anatomical location on the composition of fatty acids in double-muscled Belgian Blue cows. Meat Science v. 50 p. 45-53, 1998

WHALE, K.W.J.; S.D. HEYS; B. MAJUMDER; P. BAKER; H.J. SONG; A. SNEDDON; C. BESTWICK; S. McCLINTON; I. GRANT. CLA modulate apoptotic and anti-cancer signal mechanisms in breast ans prostate cells. In: INTERNATIONAL CONFERENCE ON CLA, 1. Alesund, 2001. Proceedings. Alesund: NATURAL ASA, 2001, p. 11.

WHITLOCK, L.A.; SCHINGOETHE, D.J.; HIPPEN, A.R.; KALSCHEUR, K.F.; BAER, R.J.; RAMASWAMY, N.; KASPERSON, K.M. Fish Oil and Extruded Soybeans Fed in Combination Increase Conjugated Linoleic Acids in Milk of Dairy Cows More Than When Fed Separately. Journal of Dairy Science v. 85 p. 234-243, 2002.

WILLIAMS, J.E.; WAGNER, D.G.; WALTERS, L.E.; HORN, G.W.; WALLER, G.R.; SIMS, P.L.; GUENTHER, J.J. Effect of production systems on performance, body composition and lipid and mineral profiles of soft tissue in cattle. Journal of Animal Science. v.57, n.4, p.1020-1028, 1983.

WILLIANS, C. M. Dietary fatty acids and human health. Annales Zootechnie. v. 49, p.165-180, 2000.

WONSIL, B. J., HERBEIN, J. H., WATKINS, B. A. Dietary and ruminally derived trans-18:1 fatty acids alter bovine milk lipids. Journal of Nutrition v.124 p. 556-565. 1994.

XU, J.; TERAN-GARCIA, M.; PARK, J.H.Y.; NAKAMURA, M.T.; CLARKET, S.D. Polyunsaturated Fatty Acids Suppress Hepatic Sterol Regulatory Element-binding Protein-1 Expression by Accelerating Transcript Decay. The Journal of Biological Chemestry. v. 276, p. 9800-9807, 2001. 
Apêndice 1 - Caracterização dos animais dos quais foram coletadas as amostras de leite

\begin{tabular}{|c|c|c|c|c|c|c|c|c|}
\hline Alimento & Fazenda & Época & Raça & $\begin{array}{c}\text { Paridade } \\
\text { Média } \pm \mathbf{d p}^{2}\end{array}$ & $\begin{array}{c}\text { DPP }^{1} \\
\text { Média } \pm d p\end{array}$ & $\begin{array}{c}\text { Produção (kg) } \\
\text { Média } \pm \text { dp }\end{array}$ & $\begin{array}{l}\text { \% Gordura } \\
\text { Média } \pm \text { dp }\end{array}$ & $\begin{array}{l}\% \text { Proteína } \\
\text { Média } \pm d p\end{array}$ \\
\hline Leite 1 & F. Barreto & Águas & Gir & $2 \pm 1.17$ & $159 \pm 71$ & $7.2 \pm 2.0$ & $4.2 \pm 0.8$ & $3.5 \pm 0.3$ \\
\hline Leite 2 & T. Vermelha & Águas & Gir & $5 \pm 1.75$ & $109 \pm 85$ & $7.1 \pm 2.1$ & $4.1 \pm 0.5$ & $3.4 \pm 0.3$ \\
\hline Leite 3 & Americana & Águas & Gir & nd & $\mathrm{Nd}$ & $7.6 \pm 1.9$ & $4.2 \pm 0.6$ & $3.5 \pm 0.3$ \\
\hline Leite 4 & Embrapa & Águas & Holandês & $2 \pm 0.55$ & $306 \pm 64$ & $21.1 \pm 6.5$ & $3.7 \pm 0.7$ & $3.2 \pm 0.2$ \\
\hline Leite 5 & S. Bárbara & Águas & Holandês & $2 \pm 2.00$ & $222 \pm 71$ & $17.0 \pm 3.1$ & $3.6 \pm 0.4$ & $3.2 \pm 0.1$ \\
\hline Leite 6 & N. Larga & Águas & Holandês & $1 \pm 0.41$ & $340 \pm 145$ & $15.5 \pm 1.9$ & $3.4 \pm 0.3$ & $3.3 \pm 0.1$ \\
\hline Leite 7 & F. Barreto & Seca & Gir & $2 \pm 1.20$ & $203 \pm 126$ & $8.7 \pm 3.0$ & $4.1 \pm 0.5$ & $3.6 \pm 0.3$ \\
\hline Leite 8 & T. Vermelha & Seca & Gir & $7 \pm 2.60$ & $130 \pm 91$ & $4.0 \pm 0.5$ & $4.6 \pm 0.8$ & $3.0 \pm 0.2$ \\
\hline Leite 9 & Americana & Seca & Gir & nd & $\mathrm{Nd}$ & $4.2 \pm 0.8$ & $4.3 \pm 0.5$ & $3.5 \pm 0.2$ \\
\hline Leite 10 & Embrapa & Seca & Holandês & $2 \pm 0.84$ & $159 \pm 132$ & $25.6 \pm 9.0$ & $3.5 \pm 0.6$ & $3.3 \pm 0.3$ \\
\hline Leite 11 & S. Bárbara & Seca & Holandês & $3 \pm 1.52$ & $203 \pm 115$ & $16.8 \pm 7.6$ & $3.6 \pm 0.3$ & $3.1 \pm 0.2$ \\
\hline Leite 12 & N. Larga & Seca & Holandês & $2 \pm 1.69$ & $156 \pm 91$ & $23.6 \pm 7.9$ & $3.5 \pm 0.5$ & $3.2 \pm 0.2$ \\
\hline
\end{tabular}

\footnotetext{
${ }^{1}$ DPP Dias pós parto

2 dp Desvio padrão
} 
Apêndice 2 - Descrição da alimentação utilizada em cada uma das 6 fazendas amostradas

\begin{tabular}{|c|c|c|c|c|c|}
\hline Alimento & Fazenda & Época & Raça & Volumosos (Pasto/Outros ${ }^{1}$ ) & Concentrados $^{2}$ \\
\hline Leite 1 & F. Barreto & Águas & Gir & $\begin{array}{c}\text { Napier (Pennistum purpureum), Capineira de } \\
\text { Milho (Planta Inteira) }\end{array}$ & $\begin{array}{c}\text { Ração Comercial > } 10 \text { kg de leite } \\
\text { (4 kg leite: } 1 \mathrm{~kg} \text { ração) }\end{array}$ \\
\hline Leite 2 & T. Vermelha & Águas & Gir & Braquiária (Brachiaria decumbens ) & Ração Comercial (2 kg/cabeça.dia) \\
\hline Leite 3 & Americana & Águas & Gir & Braquiária (Brachiaria decumbens ) & Ração Polpa Citrus e F. Algodão (4 kg/cabeça.dia) \\
\hline Leite 4 & Embrapa & Águas & Holandês & Tobiatã e Tanzânia (Panicum maximum) & Ração F.Soja, Milho e uréia (3 kg leite: $1 \mathrm{~kg}$ ração) \\
\hline Leite 5 & S. Bárbara & Águas & Holandês & Mombaça (Panicum maximum) & $\begin{array}{l}\text { Polpa de Citrus, Cevada, F. Soja, } \\
\text { Soja Grão, Uréia (5 a 10kg/cab.dia) }\end{array}$ \\
\hline Leite 6 & N. Larga & Águas & Holandês & $\begin{array}{c}\text { Braquiária (Brachiaria decumbens); Capineira } \\
\text { de Napier (Pennistum purpureum) }\end{array}$ & Ração Comercial (3 kg leite: 1 kg ração) \\
\hline Leite 7 & F. Barreto & Seca & Gir & $\begin{array}{c}\text { Napier (Pennistum purpureum) }(80 \%) ; \\
\text { Braquiária (Brachiaria decumbens ) }(20 \%) ; \\
\text { Silagem de Milho }\end{array}$ & $\begin{array}{l}\text { Ração comercial > } 10 \mathrm{~kg} \text { de leite } \\
\qquad(4 \mathrm{~kg} \text { leite: } 1 \mathrm{~kg} \text { ração) }\end{array}$ \\
\hline Leite 8 & T. Vermelha & Seca & Gir & $\begin{array}{c}\text { Braquiária (Brachiaria decumbens); Silagem } \\
\text { Sorgo (20 kg/cab.dia) }\end{array}$ & Ração Comercial (2 kg/cab.dia) \\
\hline Leite 9 & Americana & Seca & Gir & $\begin{array}{c}\text { Estrela (Cynodon nlemfuensis ); Capineira } \\
\text { Napier (Pennistum purpureum); Cana de } \\
\text { Açúcar }\end{array}$ & $\begin{array}{l}\text { P. Citrus }(39 \%) \text { e Cama de Frango }(59 \%) \\
4 \mathrm{~kg} / \mathrm{cab} . \text { dia }\end{array}$ \\
\hline Leite 10 & Embrapa & Seca & Holandês & $\begin{array}{c}\text { Tobiatã e Tanzânia (Panicum maximum); } \\
\text { Silagem de Milho }\end{array}$ & Ração F.Soja, Milho e uréia (3kg leite:1ração) \\
\hline Leite 11 & S. Bárbara & Seca & Holandês & $\begin{array}{c}\text { Mombaça (Panicum maximum); Silagem de } \\
\text { Milho:Cana de Açúcar }(1: 1)\end{array}$ & Ração (Milho, P.Citrus, refinazil, f. soja,Uréia) \\
\hline Leite 12 & N. Larga & Seca & Holandês & Aveia preta (Avena strigosa) & Ração Comercial (3 kg leite: 1 kg ração) \\
\hline
\end{tabular}

${ }^{1}$ Quando não especificado como capineira, silagem, etc a forragem era pastejada pelo animal

${ }^{2}$ Ração Comercial de composição indeterminada, mas normalmente composta por polpa cítrica, milho, farelo de trigo e farelos de oleaginosas para teor de proteína bruta próximo a $20 \%$ 

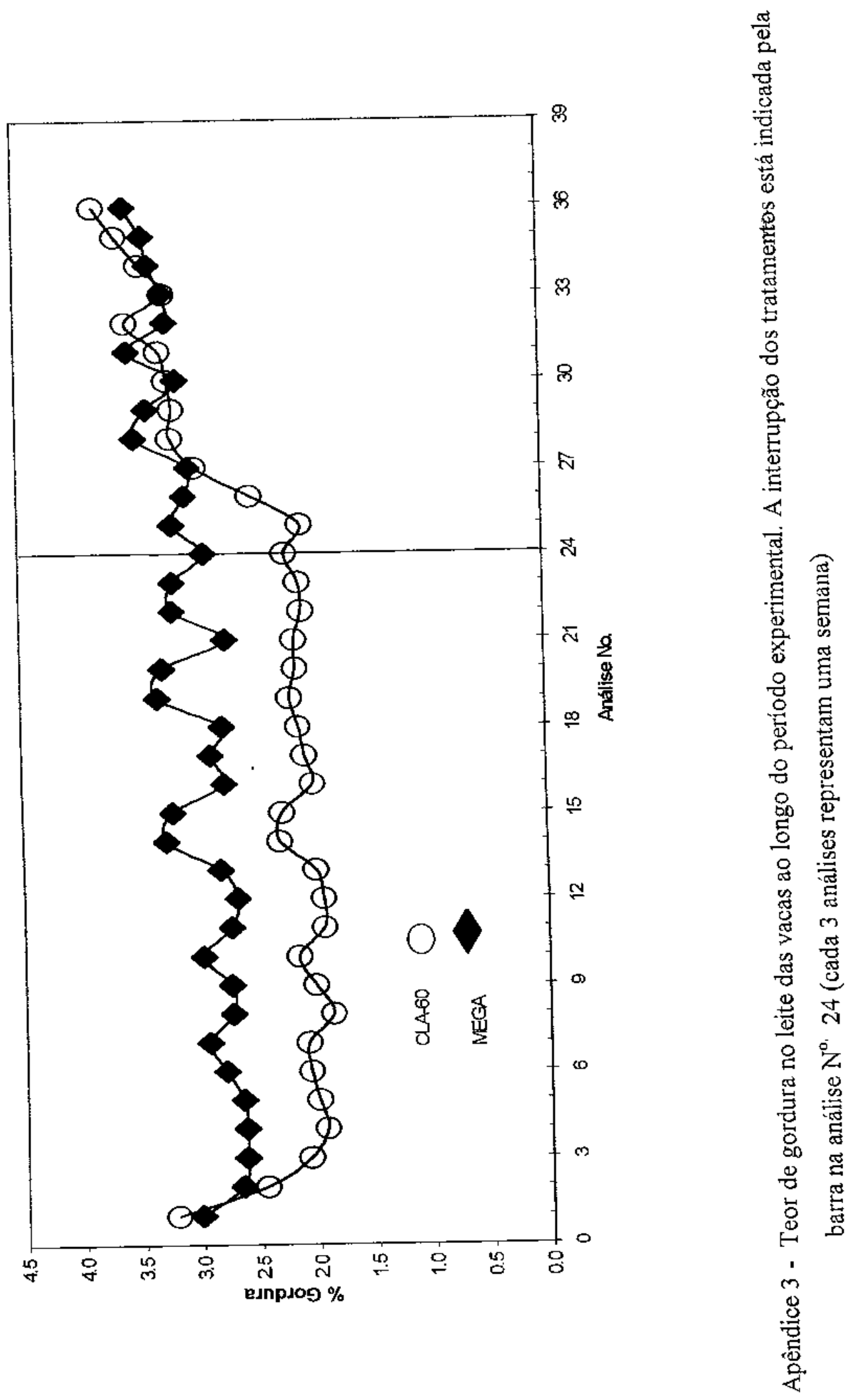